UNIVERSIDADE DE BRASÍLIA INSTITUTO DE GEOCIÊNCIAS PÓS-GRADUAÇÃO EM GEOCIÊNCIAS APLICADAS

Dissertação de Mestrado No 85

\title{
INTEGRAÇÃO DOS MÉTODOS AHP E SIG COMO INSTRUMENTO DE ANÁLISE DO NÍVEL DE QUALIDADE AMBIENTAL EM BACIAS HIDROGRÁFICAS: ESTUDO DE CASO BACIA DO RIO MELCHIOR - DF
}

Autor: Raylton de Carvalho Gomes Orientador: Prof. Dr. Edilson de Souza Bias

Brasília

2015 


\title{
INTEGRAÇÃO DOS MÉTODOS AHP E SIG COMO INSTRUMENTO DE ANÁLISE DO NÍVEL DE QUALIDADE AMBIENTAL EM BACIAS HIDROGRÁFICAS: ESTUDO DE CASO BACIA DO RIO MELCHIOR - DF
}

RAYLTON DE CARVALHO GOMES

Orientador: Prof. Dr. Edilson de Souza Bias

\begin{abstract}
Dissertação de Mestrado apresentada à Banca Examinadora do Instituto de Geociências Aplicadas (Geoprocessamento e Análise Ambiental) da Universidade de Brasília, como requisito para obtenção do título de mestre em Geociências
\end{abstract}

Brasília 
UNIVERSIDADE DE BRASÍLIA

INSTITUTO DE GEOCIÊNCIAS

\author{
INTEGRAÇÃO DOS MÉTODOS AHP E SIG COMO \\ INSTRUMENTO DE ANÁLISE DO NÍVEL DE QUALIDADE \\ AMBIENTAL EM BACIAS HIDROGRÁFICAS: ESTUDO DE CASO
}

BACIA DO RIO MELCHIOR - DF

RAYLTON DE CARVALHO GOMES

Prof. Dr. Edilson de Souza Bias

Orientador

Prof. Dr. Detlef Hans-Gert Walde

Membro Interno

Prof. Dr. Nilson Clementino Ferreira

Membro Externo

Brasília

2015 
"Rir muito e com frequência; ganhar o respeito de pessoas inteligentes e o afeto das crianças; merecer a consideração de críticos honestos e suportar a traição de falsos amigos; apreciar a beleza, encontrar o melhor nos outros; deixar o mundo um pouco melhor, seja por uma saudável criança, um canteiro de jardim ou uma redimida condição social; saber que ao menos uma vida respirou mais fácil porque você viveu. Isso é ter tido sucesso."

Ralph Waldo Emerson

"Mestre não é quem sempre ensina, mas quem, de repente, aprende" 


\section{AGRADECIMENTOS}

Inúmeras pessoas contribuíram de forma decisiva para que este trabalho viesse a se tornar realidade, sendo assim, deixo meus sinceros agradecimentos:

Agradeço primeiramente à Deus, por sua graça.

E, de forma muito especial, agradeço a minha querida mãe Maria Walquiria pelo incentivo, amor e determinação, ao meu saudoso pai Renato que está sempre vivo em minha memória e aos meus irmãos Rayssa e Renan.

Ao Prof. Dr. Edilson Souza Bias, pela oportunidade, confiança e apoio sempre irrestrito, além de dividir comigo, durante o processo de orientação, sua imensa sabedoria, mais que um consumado orientador, será sempre um amigo.

À Universidade de Brasília - UnB, em especial, o Instituto Geociências - IG, por todo apoio recebido desde o início até o término do mestrado. À Coordenação de Aperfeiçoamento de Pessoal de Nível Superior - CAPES pela bolsa de estudos concebida durante os últimos dois semestres do mestrado.

À minha querida namorada companheira e motivadora, Mayara Ferreira, com quem dividi todos os momentos de angústia, contanto sempre com sua compreensão e carinho.

Aos meus amigos de longa data, Lucijane Monteiro, Alexandre Nedredo, Celina Fernandes, João Pedro, Jhonata Carneiro e, em especial, Estéfani Santos e Weeberb Réquia.

Também agradeço a todos aqueles que, por lapso, não tenham sido aqui mencionados e que direta ou indiretamente fizeram parte da minha formação. 


\section{LISTA DE ILUSTRAÇÕES}

Figura 1: Divisão das Regiões Hidrográficas Brasileiras. Fonte: LOPES (2010) ........... 22

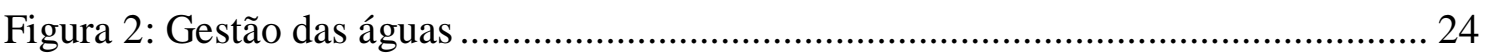

Figura 3: Histórico legislativo do planejamento e ordenamento urbano no Brasil ........ 32

Figura 4: Legislações auxiliares ao ordenamento territorial brasileiro. ........................ 33

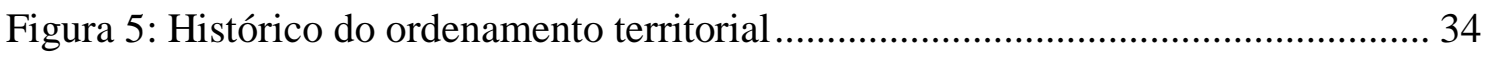

Figura 6: Estruturação hierárquica do AHP. ................................................................ 43

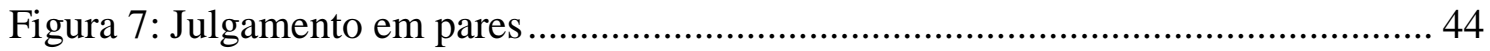

Figura 8: Mapa de localização da área de estudo ......................................................... 51

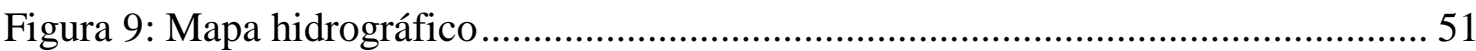

Figura 10: Rede hierárquica do levantamento do saneamento .................................. 53

Figura 11: Modelo para identificação do nível de qualidade ambiental da bacia .......... 55

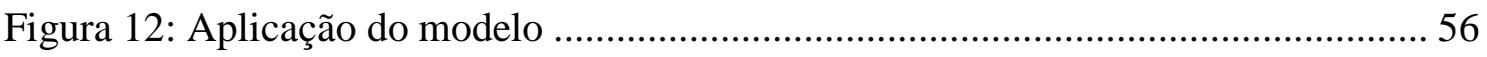

Figura 13: Etapas do processo de julgamento de peso ................................................. 57

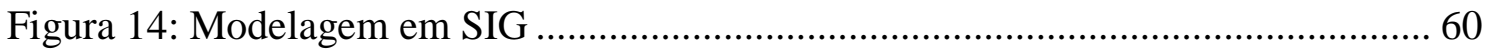

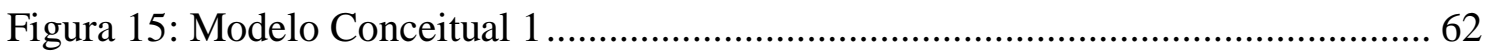

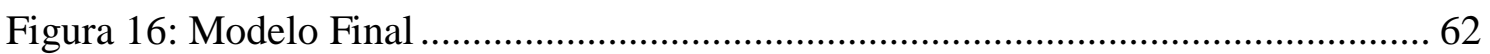

Figura 17: Etapas de elaboração do Mapa de Classificação ........................................... 63

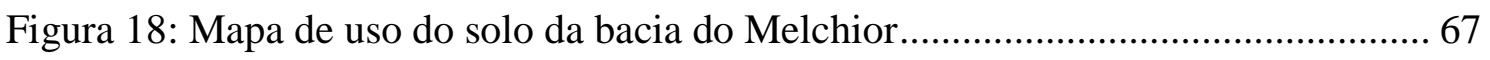

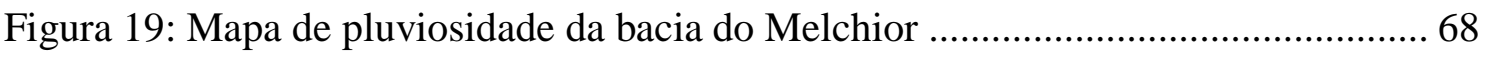

Figura 20: Mapa de declividade da bacia do Melchior ...................................................69 69

Figura 21: Mapa pedológico da bacia do Melchior.......................................................... 71

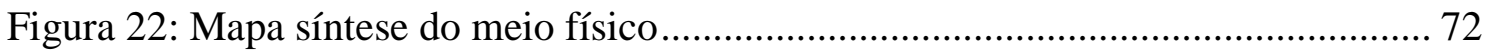

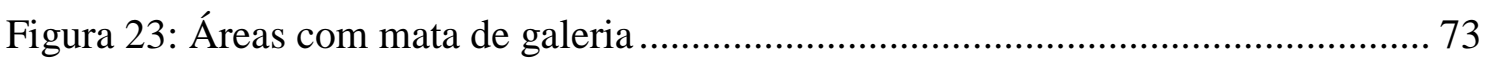

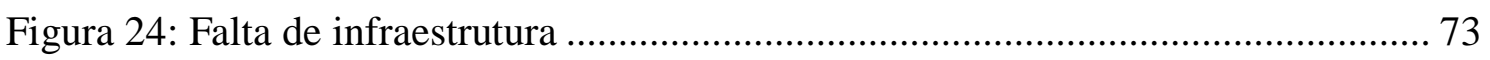

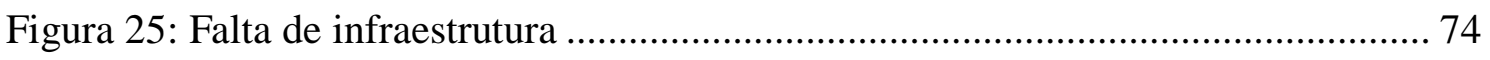

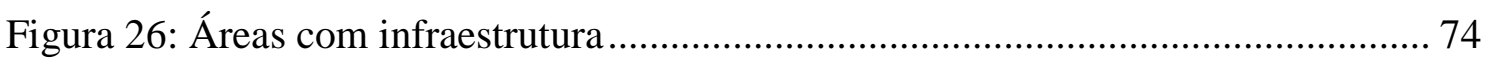

Figura 27; Áreas com infraestrutura ......................................................................... 75

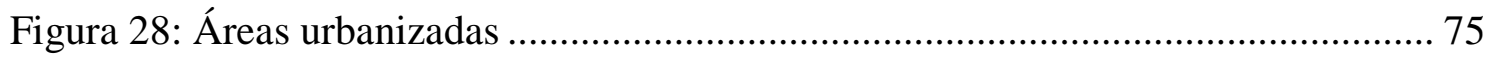

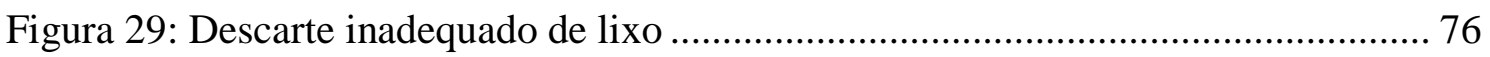

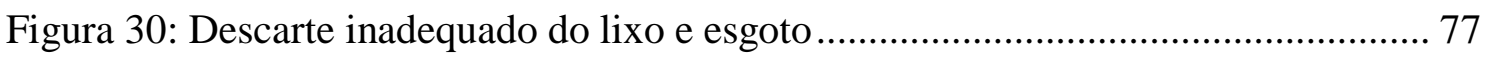


Figura 31: Domicílios particulares permanentes com banheiro de uso exclusivo dos moradores ou sanitário e esgotamento sanitário via rede geral de esgoto ou pluvial..... 78 Figura 32: Domicílios particulares permanentes com banheiro de uso exclusivo dos moradores ou sanitário e esgotamento sanitário via fossa séptica

Figura 33: Domicílios particulares permanentes com banheiro de uso exclusivo dos moradores ou sanitários e esgotamento sanitário via fossa rudimentar. 79

Figura 34: Domicílios particulares permanentes com banheiro de uso exclusivo dos moradores ou sanitários e esgotamento sanitário via vala.

Figura 35: Domicílios particulares permanentes, com banheiro de uso exclusivo dos moradores ou sanitário e esgotamento sanitário via rio, lago ou mar

Figura 36: Domicílios particulares permanentes com banheiro de uso exclusivo dos moradores ou sanitário e esgotamento sanitário via outro escoadouro

Figura 37: Domicílios particulares permanentes sem banheiro de uso exclusivo dos moradores e nem sanitário.

Figura 38: Mapa de síntese de esgotamento sanitário ....

Figura 39: Domicílios particulares permanentes com lixo coletado

Figura 40: Domicílios particulares permanentes com lixo coletado por serviço de limpeza.

Figura 41: Domicílios particulares permanentes com lixo coletado em caçamba de serviço de limpeza 84

Figura 42: Domicílios particulares permanentes com lixo queimado na propriedade ... 85

Figura 43: Domicílios particulares permanentes com lixo enterrado na propriedade .... 85

Figura 44: Domicílios particulares permanentes com lixo jogado em terreno baldio ou logradouro.

Figura 45: Domicílios particulares permanentes com lixo jogado em rio, lago ou mar. 86

Figura 46: Domicílios particulares permanentes com outro destino do lixo..... 87

Figura 47: Mapa síntese de lixo.....

Figura 48: Domicílios particulares permanentes com outra forma de abastecimento de água......

Figura 49: Domicílios particulares permanentes com abastecimento de água de rede geral 
Figura 50: Domicílios particulares permanentes com abastecimento de água da chuva armazenada em cisterna

Figura 51: Domicílios particulares permanentes com abastecimento de água de poço ou

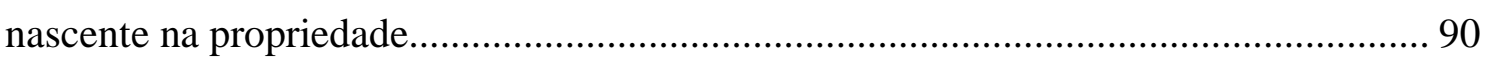

Figura 52: Mapa síntese de abastecimento de água..................................................... 90

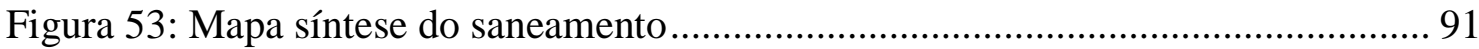

Figura 54: Áreas com maior nível de qualidade ambiental .......................................... 92

Figura 55: Mapa de qualidade ambiental da bacia do Rio Melchior - DF .................... 93

Figura 56: Falta de infraestrutura e descarte inadequado de resíduos ........................... 94

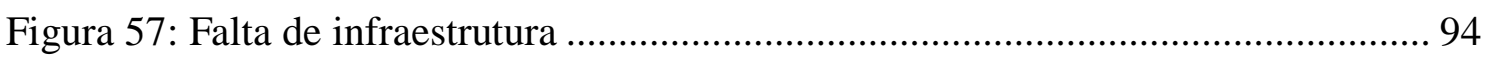

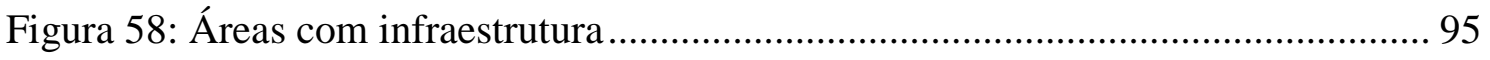

Figura 59: Áreas com nível de qualidade ambiental alto ........................................... 95

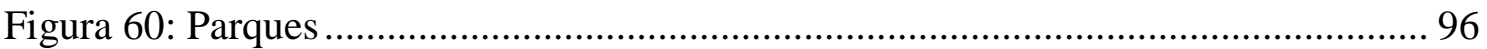

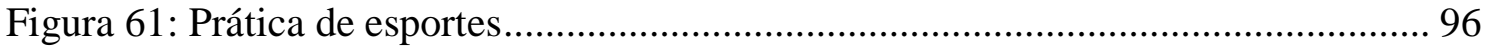

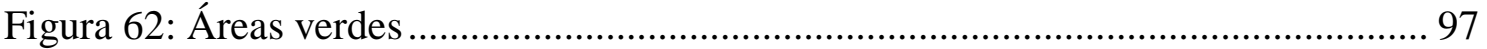

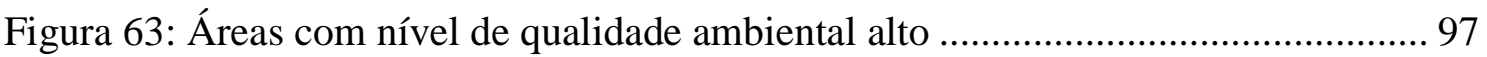

Figura 64: Áreas classificadas com o nível de qualidade médio ................................... 98

Figura 65: Pequenas ocupações localizadas na bacia ................................................... 98 


\section{LISTA DE TABELAS}

Tabela 1: Evolução dos sistemas sensores. Fonte: adaptação de Marinho., (2014) ...... 45

Tabela 2: Alguns Sensores imageadores conforme sua resolução espacial ................... 47

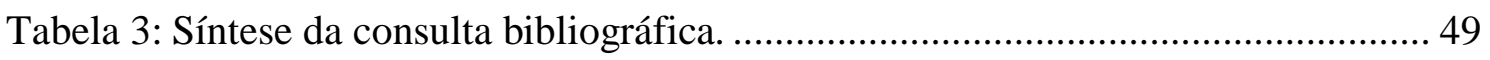

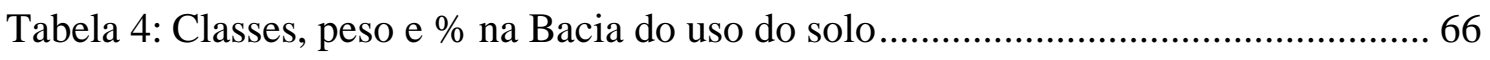

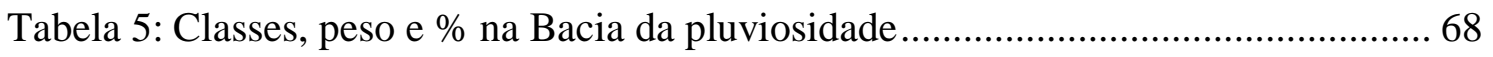

Tabela 6: Classes, peso e \% na Bacia de declividade....................................................... 69

Tabela 7: Classes, peso e \% na Bacia de pedologia ......................................................... 70 


\section{LISTA DE QUADROS}

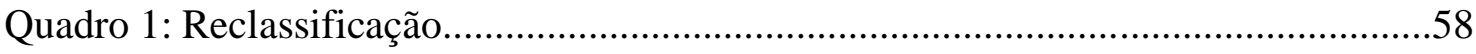

Quadro 2: Resultado do julgamento de pesos..........................................................64 


\section{LISTA DE SIGLAS}

Sistema de Informação Geográfica (SIG)

Avaliação de Impacto Ambiental (AIA)

Área de Proteção Ambiental (APA)

Reserva Legal (RL)

Unidade de Conservação (UC)

Unidade de Proteção Integral (UPI)

Unidade de Uso Sustentável (UUS)

Estudo de Impacto Ambiental (EIA)

Relatório de Impacto Ambiental (RIMA)

Organização Não Governamental (ONG)

Secretaria de Desenvolvimento Habitacional (SEDHAB)

Instituto de Pesquisas (INPE)

Política de Desenvolvimento Urbano (PDU)

Zoneamento Ecológico Econômico (ZEE)

Sociedade Brasileira para o Progresso da Ciência (SBPC)

Plano Diretor Local (PDL)

Plano de Gestão Ambiental (PGA)

Sociedade Brasileira para o Progresso da Ciência (SBPC)

Secretaria Especial do Meio Ambiente (SEMA)

Sistema Nacional de Meio Ambiente (SISNAMA)

Política Nacional de Meio Ambiente (PNMA)

Política Nacional de Resíduos Sólidos (PNRS)

Instituto Nacional de Pesquisas Espaciais (INPE)

Agência Nacional de Águas (ANA)

Conselho Nacional de Recursos Hídricos (CNRH)

Sistema Nacional de Gerenciamento de Recursos Hídricos (SNGRH)

Plano Nacional de Recursos Hídricos (PNRH)

Conselho Nacional de Meio Ambiente (CONAMA)

Instituto Brasileiro do Meio Ambiente e dos Recursos Naturais (IBAMA)

Companhia de Saneamento Ambiental do DF (CAESB) 
Ministério do Meio Ambiente (MMA)

Sistema Nacional de Unidades de Conservação da Natureza (SNUC)

Plano Diretor de Ordenamento Territorial (PDOT)

Plano Nacional de Ordenamento Territorial (PNOT)

Plano de Estruturação e Organização Territorial do Distrito Federal (PEOT)

Plano de Ocupação Territorial (POT)

Plano de Ocupação e Uso do solo (POUSO) 


\section{RESUMO}

As alterações ambientais originadas pela sociedade são quase tão antigas quanto a existência do ser humano. Desse modo, junto com o crescimento demográfico e o alto grau tecnológico observou-se que os impactos ambientais se tornavam mais intensos. Devido a isso, a partir do século XX, surgiu uma maior preocupação por parte das autoridades competentes. Para tanto, organizações não governamentais e sociedade civil uniram-se na discussão da implementação de políticas públicas voltadas tanto para o planejamento quanto para a gestão ambiental de bacias hidrográficas. O presente trabalho buscou determinar o nível de qualidade ambiental da bacia do Rio Melchior, DF, Brasil. Para isso, foi desenvolvido um modelo para identificação do nível de qualidade dessa, com alternativas e critérios do meio físico e saneamento da bacia. Os referidos critérios e alternativas do modelo passaram por um processo de julgamento de pesos por meio do método multicritério Analytic Hierachy Process (AHP) com auxilio do Software Expert Choice versão 3.01. Na elaboração do produto temático um mapa do nível de qualidade ambiental da bacia utilizou a operação conhecida como álgebra de mapas, que faz uso de funções matemáticas com constante escalar ou o simples uso de uma operação aritmética. As operações algébricas com os mapas foram feitas de acordo com os pesos definidos e estabelecidos pelo AHP. Os resultados da integração do AHP e Sistema de Integração Geográfica (SIG) mostraram que as variáveis relacionadas ao meio físico (uso do solo, pluviosidade, pedologia e declividade) saneamento (água, esgoto e lixo) permitiram conhecer o Nível de Qualidade Ambiental. No resultado final o Mapa de Qualidade Ambiental da Bacia, observou-se que $56 \%$ da área total da bacia foi classificada com o nível de qualidade ambiental média e alta, locais de preservação ambiental e parque, $32 \%$ nula e baixa, áreas urbanizadas com e sem infraestrutura e 12\% classificada como muito alta, áreas próximas a córregos e nascentes de preservação permanente. Dessa forma, as variáveis apresentadas no estudo são eficientes para diagnosticar a fragilidade da bacia e fornecer indicativos para a tomada de decisão no âmbito do processo de planejamento e de gestão territorial de Bacias Hidrográficas.

Palavras chaves: Planejamento Ambiental, Método Multicritério, Sistema de Informação Geográficas, Ordenamento Territorial, Bacia Hidrográfica do Melchior. 


\begin{abstract}
Environmental changes caused by the society are almost as old as human existence. Thus, along with the demographic growth and high technological level it is observed that the environmental impacts became more intense. Because of this, from the twentieth century, there was a greater concern on the part of the competent authorities. To this end, nongovernmental organizations and civil society have joined in implementing the discussion of public policies both for planning and for environmental management of watersheds. This study sought to determine the level of environmental quality of the river basin Melchior, DF, Brazil. For this, a model was developed to identify the level of quality that, with alternative criteria and the physical and social environment of the basin. These criteria and model alternatives went through a process of trial weights through the Analytic Hierarchy Process multi-criteria method (AHP) with the aid of Expert Choice Software version 3.01. In preparing the thematic product a map of the environmental quality level of the basin used the operation known as map algebra, which makes use of mathematical functions with constant climbing or the simple use of an arithmetic operation. Algebraic operations with maps were made in accordance with the weights defined and established by the AHP. The results of the AHP integration and Geographic Integration System (GIS) showed that the variables related to the physical environment (land use, rainfall, soil conditions and slope) sanitation (water, sewer and garbage) allowed knowing the Environmental Quality Level. In the final result the Environmental Quality Basin map, it was observed that $56 \%$ of the total basin area was classified to the level of middle and high environmental quality, environmental preservation and park sites, 32\% null and low urbanized areas and without infrastructure and 12\% classified as very high, areas near streams and springs of permanent preservation. Thus, the variables presented in the study are efficient to diagnose the fragility of the basin and provide indications for decision-making within the planning process and land management Watershed.
\end{abstract}

Key words: Environmental Planning, Multi-criteria method, Geographic Information System, Land Management, Basin Melchior. 


\section{SUMÁRIO}

INTRODUÇÃO .................................................................................................................. 19

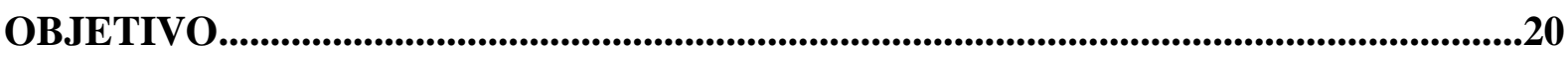

CAPÍTULO 1 - REVISÃO DA LITERATURA ............................................................... 21

1.1 BACIA HIDROGRÁFICA - CONCEITOS, LEGISLAÇÃO E IMPORTÂNCIA ..........................21

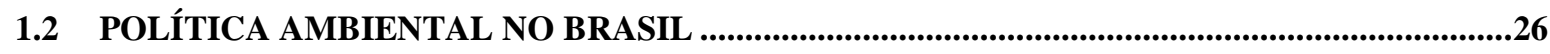

1.3 PLANEJAMENTO NAS BACIAS HIDROGRÁFICAS.................................................................28

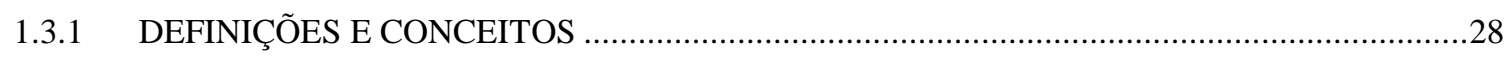

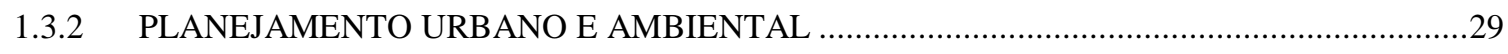

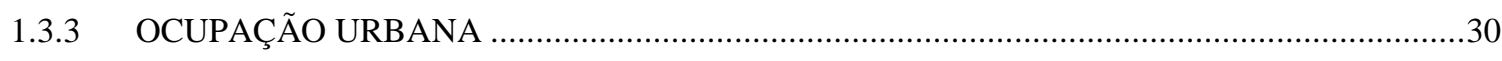

1.3.4 PLANO DIRETOR DE ORDENAMENTO TERRITORIAL DO DISTRITO FEDERAL

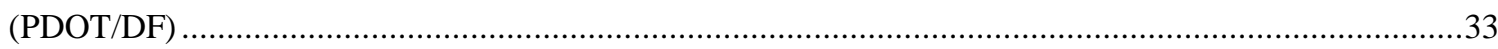

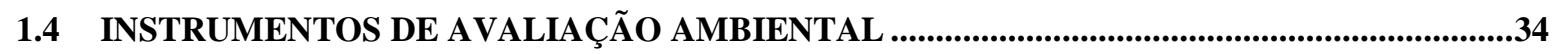

1.4.1 ESTUDO DE IMPACTOS AMBIENTAIS (EIA) E RELATÓRIO DE IMPACTOS

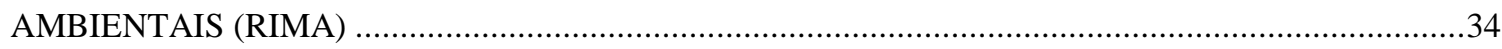

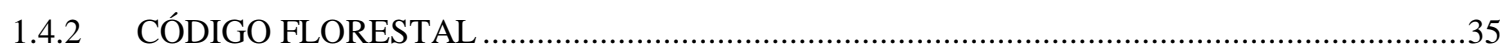

1.4.3 POLÍTICA NACIONAL DE RESÍDUOS SÓLIDOS ………...................................................

1.5 SISTEMAS DE INFORMAÇÕES GEOGRÁFICAS (SIG) COMO APOIO PARA GESTÃO DE

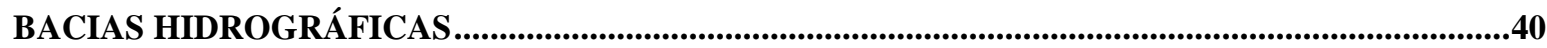

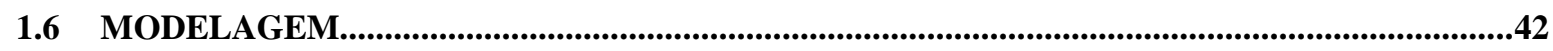

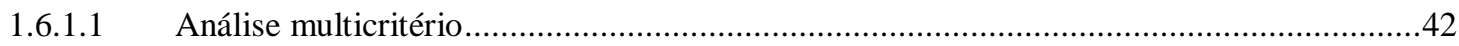

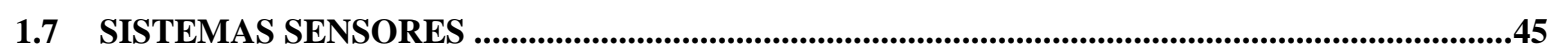

CAPÍTULO 2 - MATERIAIS E MÉTODOS ...........................................................................50

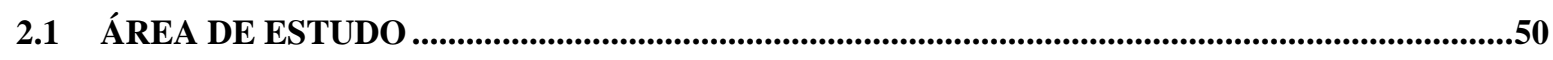

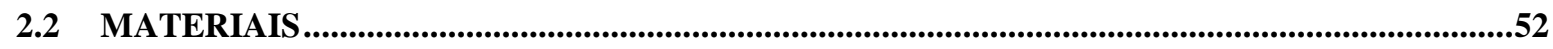

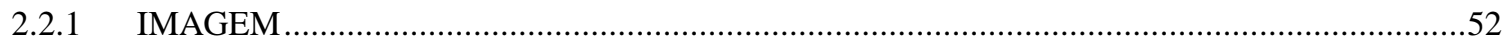

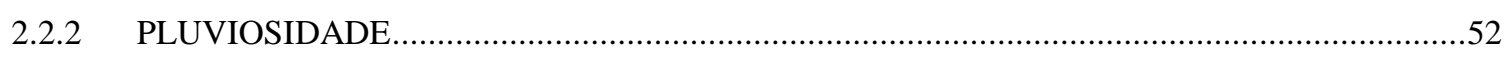

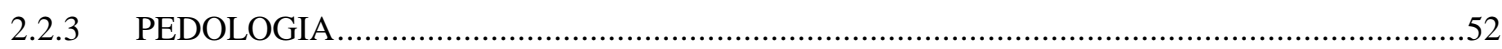




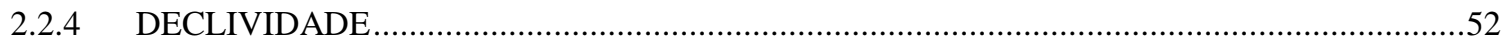

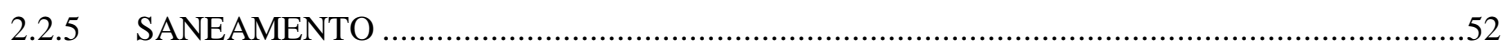

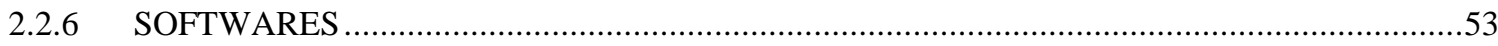

2.3 MÉTODOS

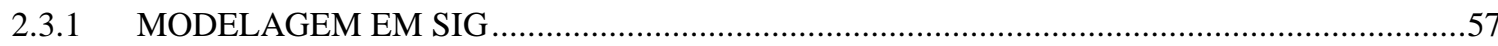

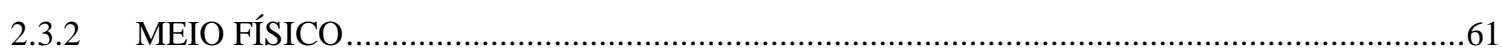

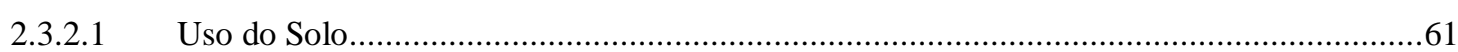

CAPÍTULO 3 - RESULTADO E DISCUSSÕES ..............................................................63

3.1 MAPA DO NÍVEL DE CONSERVAÇÃO AMBIENTAL DA BACIA DO MELCHIOR ..............92

CAPÍTULO 4 - CONCLUSÕES..............................................................................................99

CAPÍTULO 5 - RECOMENDAÇÕES ..................ERRO! INDICADOR NÃO DEFINIDO. 


\section{Introdução}

Umas das principais bacias hidrográficas do Distrito Federal - DF é a do Rio Melchior ela é parte integrante da bacia do Rio Descoberto, que por sua vez é responsável pelo abastecimento de aproximadamente $60 \%$ da água potável destinada ao consumo da população do DF. A gestão e a preservação dos recursos hídricos são de extrema importância para sustentabilidade da sociedade local e o bom funcionamento da bacia.

A falta de planejamento tem produzido resultados desastrosos nas ações de gestão em bacias hidrográficas, o que tem gerado um avanço na degradação da qualidade ambiental e compromete o sucesso das ações de gestão neste setor. Isso se dá devido às ocupações irregulares do solo que crescem junto com o crescimento populacional do Distrito Federal DF.

Essas ocupações sem o devido planejamento constituem ameaças ao meio ambiente, pois traz consigo impactos negativos ao solo, água, ar e biodiversidade e na sociedade local. Dos impactos mais visíveis em bacias hidrográficas, destacam-se: o desmatamento e a destruição do habitat, os problemas com manejo do solo (erosão, salinização e perda de fertilidade), introdução de outras espécies sobre as nativas, queimadas, mudanças climáticas, e aumento de produtos tóxicos no ambiente (FRANCO, 2009).

A preocupação de mitigação e eliminação dos impactos ambientais manifestou-se a partir da Lei de Direito das Águas (Decreto n. ${ }^{2}$.463), instituída em 1934 e considerada um modelo para a evolução do Direito Ambiental Brasileiro, posteriormente a Constituição Federal promulgada em 05 de outubro de1988 e a Política Nacional de Recursos Hídricos (PNRH) de 08 de janeiro de 1997.

O planejamento ambiental tem como um de seus objetivos a aplicação das políticas voltadas ao uso dos recursos hídricos, de forma a garantir as condições ecológicas para o desenvolvimento efetivo da produção social, e todas as atividades da população, do uso racional e da proteção dos recursos do meio ambiente (PEIXOTO, 2005; NOVAIS, 2011).

O Plano Nacional de Ordenamento Territorial - PNOT e o Plano de Ordenamento Territorial - PDOT são instrumentos utilizados no planejamento ambiental urbano, sua 
importância se dá pelo fato de ser usado para a conectividade entre as diferentes instruções normativas no âmbito do uso, ocupação e proteção do solo urbano e rural que, apesar de estarem relacionadas, não são observadas gerando redundância ou conflitos(SEDHAB, 2014).

Dentre os objetivos do PDOT estão os da melhoria da qualidade de vida da população, o resguardo do patrimônio ambiental, otimização do desenvolvimento urbano e rural de acordo com a infra estrutura e disponibilidade de serviços a fim de manter tal uso dentro de uma gestão participativa com a sociedade civil (SEDHAB, 2014, 2015).

Dessa forma, as realizações de estudos com foco no planejamento ambiental das bacias hidrográficas servem de subsídio para conhecer as suas fragilidades e fornecer indicativos para a tomada de decisão no âmbito do processo de planejamento e de gestão territorial.

\section{Objetivo}

O objetivo geral do presente projeto e analisar o nível de qualidade ambiental na bacia do Rio Melchior - DF.

Para atingir o objetivo geral, foram propostos os seguintes objetivos específicos:

1. Implementar modelo de análise baseado em ferramenta AHP e SIG;

2. Efetuar a integração de dados físicos e sócioeconômicos da bacia;

3. Elaborar o mapa do nível de qualidade ambiental da bacia do Melchior. 


\section{Capítulo 1 - Revisão da Literatura}

\subsection{BACIA HIDROGRÁFICA - CONCEITOS, LEGISLAÇÃO E IMPORTÂNCIA}

A água é um dos recursos naturais renováveis de maior importância para a humanidade, e as bacias hidrográficas são os elementos responsáveis pelos processos de armazenamento, concentração e distribuição das águas doces (TUCCI, 1997).

Ao longo do tempo surgiram diversas definições e conceitos para bacia hidrográfica. Contudo, segundo a definição de Tucci, (1997), a bacia hidrográfica é uma área de captação de água da precipitação, que ocorre de forma natural e que através do escoamento subsuperficial converge para um único ponto de saída (exutório).

Já Teodoro et al. (2007) define as bacias hidrográficas como sendo um conjunto de terras drenadas por um rio e seus afluentes, cuja formação se dá em regiões mais elevadas de relevo, possuindo divisores das águas por onde ocorre o escoamento das precipitação, formando outros cursos d'água ou sofrendo o processo de infiltração no solo para formação do lençol freático e nascente.

Os termos sub-bacia e micro bacia hidrográfica também estão incorporados na literatura científica, contudo, não apresentam a mesma convergência conceitual apresentada para bacia hidrográfica, definidas por Tucci (1997) e Teodoro et al. (2007). Para Teodoro et al., (2007) as sub-bacias são áreas de drenagem dos tributários do curso d'água principal. A fim de definir sua área, os autores utilizam-se de diferentes unidades de medida. De acordo com Teodoro et al.(2007), as sub-bacias possuem áreas maiores que $100 \mathrm{~km}^{2}$ e menores que $700 \mathrm{~km}^{2}$, já para Martins et al., (2005), são áreas entre 20.000 ha e 30.000 ha (200 km² a 300 $\mathrm{km}^{2}$ ). Para Hein(2000), as bacias podem ser desmembradas em um número qualquer de subbacias, dependendo do ponto de saída considerado ao longo do seu eixo-tronco ou canal coletor. Sob o ponto de vista ambiental a divisão de bacias e sub-bacias pode ser feita pelo divisor de águas. 
Em um primeiro nível, o território brasileiro foi dividido em Regiões Hidrográficas por meio da Resolução no 32 do Conselho Nacional de Recursos Hídricos (CNRH),em 2003, no qual foi instituída a Divisão Hidrográfica Nacional em regiões hidrográficas como apresentado na Figura 1.

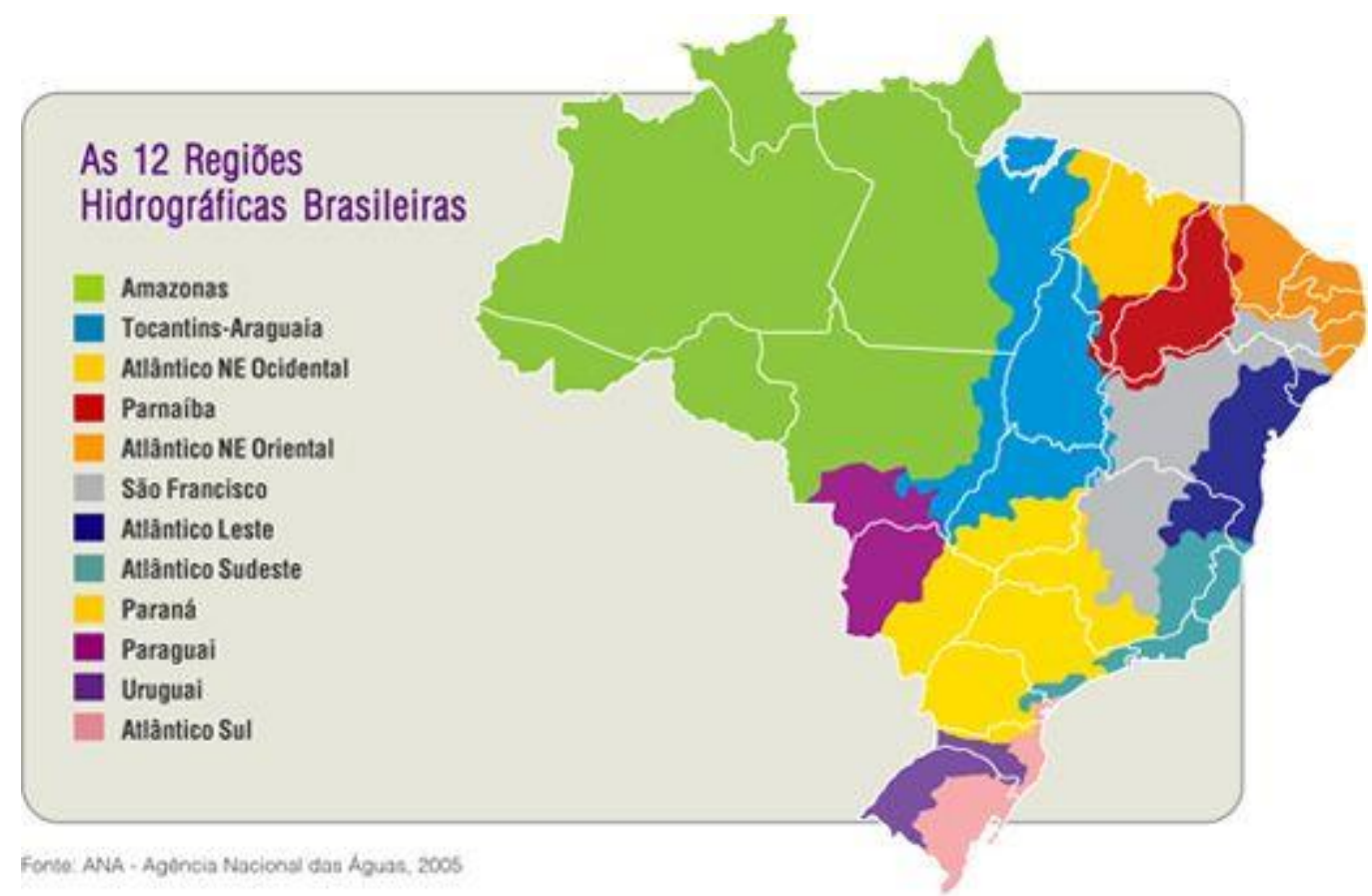

Figura 1: Divisão das Regiões Hidrográficas Brasileiras. Fonte: LOPES (2010)

Ainda conforme a Resolução no 32 da CNRH, esta divisão é justificada pelas distintas características naturais, sociais e econômicas homogêneas ou similares do país, tendo como foco a melhora no desenvolvimento da gestão e planejamento dos recursos hídricos.

Os estados brasileiros, no âmbito dos seus territórios, fizeram divisões hidrográficas para fins de gestão utilizando diferentes critérios. O Distrito Federal está divido em 7 unidades de gestão hidrográficas que são: Bacia do Descoberto, Bacia do São Bartolomeu, Bacia do Rio Preto, Bacia do Rio Maranhão, Bacia do Rio Corumbá, Bacia do Paranoá, Bacia do Rio São Marcos (IBRAM, 2015).

Baseando-se na divisão territorial das bacias hidrográficas, a gestão dos recursos hídricos passou a ganhar espaço na década de 90, a partir dos Princípios de Dublin que foram acordados na RIO92. Conforme o Princípio n.1 "a gestão dos recursos hídricos, para ser efetiva, deve ser integrada e considerar todos os aspectos, físicos, sociais e econômicos" para que essa integração tenha o foco adequado, sugere-se que a gestão esteja baseada nas bacias hidrográficas (ORGANIZATION, 1992). 
O cuidado com os recursos hídricos surge no Brasil a partir da Lei de Direito das

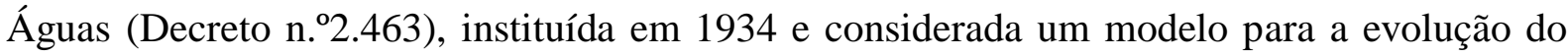
Direito Ambiental Brasileiro.

Já em 1988, surge um foco maior para a gestão das bacias hidrográficas com a Constituição Federal, sendo um marco do desenvolvimento da legislação nacional voltada aos recursos hídricos. Esta definiu a água como sendo bens de uso comum e alterou a dominialidade das águas do território nacional, fazendo com que seja de domínio público, instituindo, também, em seu Art. 21, o Sistema Nacional de Gerenciamento de Recursos Hídricos (SNGRH) e definindo critérios de outorga de direito de uso(BNDES, 1998).

Em 1997, surge a Política Nacional de Recursos Hídricos (PNRH) com a Lei 9.433, popularmente nomeada como Lei das Águas, incorporando princípios e normas para a gestão dos recursos hídricos, definindo a água como sendo um bem para consumo humano, de usos múltiplos e de domínio público. Foi a partir desta Lei e da concretização do setor que o Brasil passou a ter uma das mais avançadas legislações para gestão das águas. Ressalta-se que é de responsabilidade das três esferas federativas, a União, Estadual e Municipal a gestão compartilhada dos recursos hídricos (PORTO; PORTO, 2008).

A Lei das Águas tem entre os fundamentos da PNRH, a água como um bem de domínio público, dotado de valor econômico, cujos usos prioritários são o abastecimento humano e a dessedentação de animais, sendo que a gestão deve tomar como unidade territorial a bacia hidrográfica. Segundo a Lei das Águas, a SNGRH deve cumprir diversos objetivos, dentre eles coordenar a gestão integrada das águas e implementar a PNRH, dentre outros.

A PNRH ainda ressalta que integram o SNGRH, o Conselho Nacional de Recursos Hídricos; os Conselhos de Recursos Hídricos dos Estados e do Distrito Federal; os Comitês de Bacia Hidrográfica; os órgãos de governo cujas competências se relacionem com a gestão de recursos hídricos; e Agências de água.

A Lei que instituiu a PNRH teve seu art. 32 instrumentalizado pela Lei $n^{\circ}$ 9.984/2000, que dispõe sobre a criação da Agência Nacional de Águas (ANA), criada de forma a complementar o sistema estrutural da gestão dos recursos hídricos no Brasil, onde possui a responsabilidade do controle, da outorga e da cobrança pelo uso da água (COSTA; PERIN, 2000). 
A participação de usuários e da sociedade civil são constantes em todas as sessões constitutivas, as plenárias de elaboração da Lei, como por exemplo, no Comitê de Bacias Hidrográficas, instituídos no Art. n. ${ }^{\circ}$ 37, que apresenta função consultiva (emite pareceres), normativa (estabelece normas) e deliberativa (toma decisões) (COSTA; PERIN, 2000). A Lei visa também a descentralização do poder com a criação das Agências das Águas e dos Comitês de Bacias Hidrográficas (Figura 2), sendo que no caso dos comitês é permitido que a decisão seja tomada na própria bacia hidrográfica, auxiliando no processo de tomada de decisão(PORTO; PORTO, 2008).

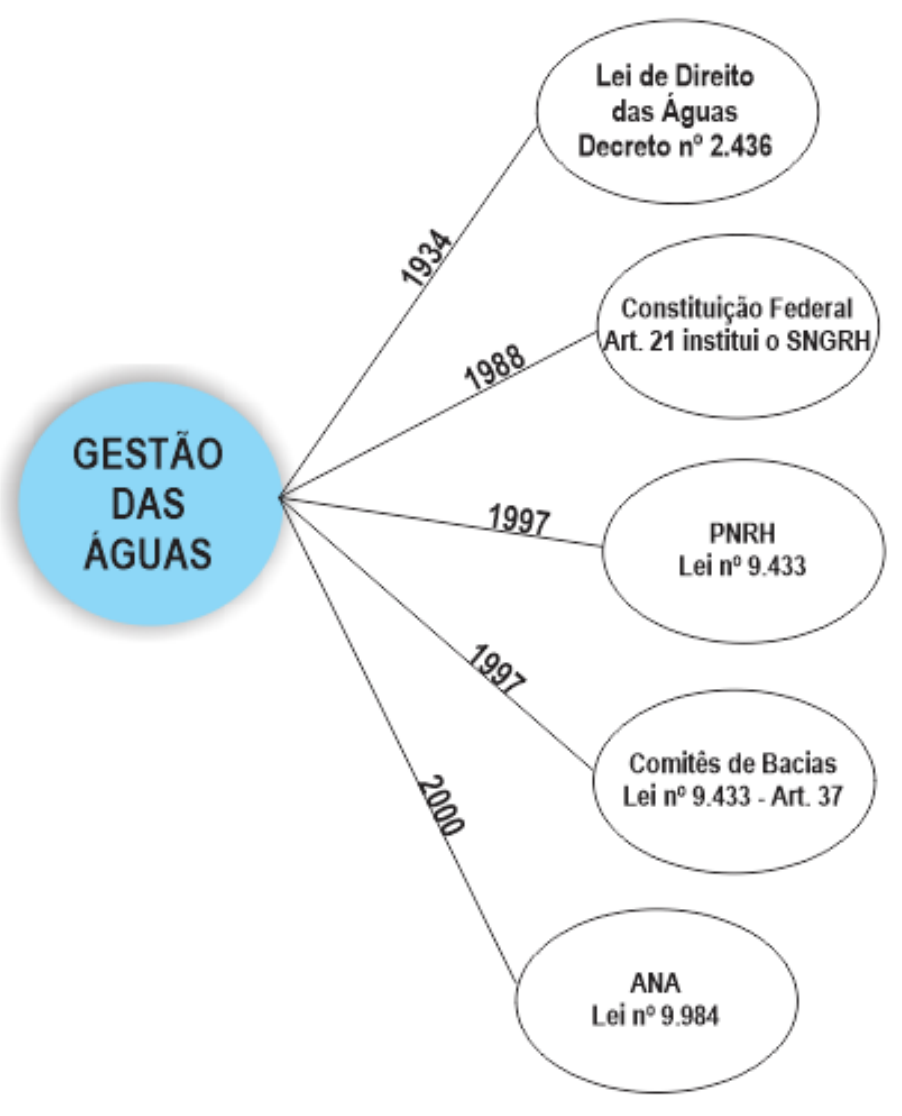

Figura 2: Gestão das águas

A Lei n. 9.433/1997 é importante para a ordenação do uso da água tratando cada região hidrográfica de forma individual, com o objetivo de valorizar suas diferenças e desenvolver estratégias de gestão específicas que dependem das condições existentes na bacia (BERNARDI et al., 2013).

As bacias hidrográficas constituem unidades ambientais de fundamental importância para estudos interdisciplinares, visando o seu manejo sustentável. Os recursos naturais que a compõem, solo, água, vegetação e o meio ambiente que a circunda estão em constantes mudanças em resposta à evolução natural e às atividades humanas (SÁ et al., 2010). 
Dentre os impactos mais visíveis em bacias hidrográficas destacam-se o desmatamento e destruição do habitat, os problemas com manejo do solo (erosão, salinização e perda e fertilidade), controle da água (caça e pesca), introdução de outras espécies sobre as nativas e aumento percapita do crescimento demográfico, queimadas, e aumento de produtos tóxicos no ambiente (FRANCO, 2009).

Para Tucci e Mendes (2006), os impactos causados pelo uso e manejo do solo da bacia podem ser classificados quanto ao tipo de uso da solo e a forma como sua alteração é provocada. De acordo com Tucci e Mendes (2006), a alteração do escoamento superficial está relacionado às ações de manejo do solo, esse impacto normalmente é caracterizado quanto ao efeito que provoca no comportamento das enchentes, nas vazões mínimas e média, além das condições ambientais locais e a jusante.

As ações de desmatamento assumem uma das problemáticas mais discutidas no Brasil. De 2004 a 2014 a degradação chegou a cerca de 13 milhões de hectares somente na Amazônia Legal, baseada em ações predatórias como exploração ilegal da madeira, além de queimadas (INPE, 2015).

Referente às queimadas, a alta carbonização de biomassa vegetal coloca o Brasil como um dos principais causadores de mudanças climáticas favorecendo o efeito estufa. Além de agredir a camada de ozônio, as queimadas ainda poluem a atmosfera, causam o desflorestamento e a perda da biodiversidade, desertificação, além de trazer prejuízos econômicos e sociais (IBAMA, 2015). Segundo dados do INPE (2015), de 2013 para 2014, o aumento de focos de incêndio foi de $62 \%$, tendo picos máximos nos meses de julho e agosto.

Dentre outras ações impactantes, destaca-se o desenvolvimento urbano descontrolado, causando preocupação quanto à preservação dos corpos hídricos, em decorrência da ocupação urbana em áreas de enchentes, geração sem coleta eficiente dos resíduos sólidos, além de despejo de cargas de esgotos sanitário e pluvial (TUCCI; MENDES, 2006).

De acordo Tucci e Mendes (2006), a impermeabilização do solo também é um fator a se destacar, devida a sua associação aos processos de urbanização, pois além de retirar a camada superficial do solo, ainda altera a capacidade de infiltração da bacia.

A Bacia Hidrográfica é classificada como unidade de gestão e planejamento, tendo seus elementos físicos naturais interligados pelo ciclo da água(SCHIAVETTI; CAMARGO, 2002; ARAÚJO et al., 2004). Além disso, apresenta a capacidade de distinguir diversos objetivos, tais como o desenvolvimento econômico e ambiental, bem como a sustentabilidade 
ambiental (SCHIAVETTI; CAMARGO, 2002; ARAÚJO et al., 2004; TEODORO et al., 2007; SÁ et al., 2010; BERNARDI et al., 2013)

A grande demanda de água doce presente no Brasil e a diversidade de recursos naturais presentes em suas bacias hidrográficas desempenham certa importância no desenvolvimento de atividades econômicas e sociais. Sendo assim, esses recursos podem ser utilizados para:

- $\quad$ navegação, sendo vias de transporte (social e de produtos);

- irrigação (agricultura/agropecuária);

- geração de energia;

- abastecimento de água potável (doméstico e industrial);

- exploração da pesca como fonte de alimento;

- mineração;

- desenvolvimento de atividades turísticas;

- exploração de petróleo e gás mineral;

- território para o desenvolvimento urbano; dentre outras.

Segundo Schiavetti e Camargo., (2002), Faria et al., (2003) e Santos e Leal., (2012) as Bacias Hidrográficas ainda se destacam por sua importância ambiental devido ao fato de:

- auxiliar no ciclo produtivo vegetal;

- apresentar auto manutenção dos recursos hídricos (Ciclo da Água);

- criar habitats para o desenvolvimento de fauna e flora;

- criar através da infiltração um estoque de águas subterrâneas; dentre outros.

O Brasil é o país que apresenta um maior percentual, com cerca de 13,8\% do total de água potável (FREITAS et al., 2000). A partir de sua abundância é possível destacar que a preservação dos recursos ambientais presentes nas bacias beneficiaram a movimentação e o enriquecimento da biodiversidade de fauna e flora (CARVALHO et al., 2012).

\subsection{POLÍTICA AMBIENTAL NO BRASIL}

A política ambiental, segundo Moraes \&Turolla, (2004) pode ser classificada com um conjunto de instrumentos à disposição do Estado, tendo a finalidade de alterar a alocação de recursos de forma a reduzir o consumo de bens e serviços escassos sujeitos a externalidades negativas, tais como: o ar, que recebe grande carga de poluentes provenientes dos processos 
de combustão e de processos industriais; os recursos hídricos que são receptores de efluentes derivados de processos industriais e às vezes de efluentes domésticos, quando os sistemas de coleta e tratamento são ineficaz ou inexistentes; dentre outros.

A utilização mais ativa de instrumentos de política ambiental pelo Estado brasileiro começou a se fortalecer ao longo da década de 70, especificamente com Conferência das Nações Unidas, em Estolcomo, Suécia, em 1972, sendo um marco para o desenvolvimento político ambiental no Brasil e no mundo(ARAÚJO et al., 2004).

Com isso, em 1973 deu-se início da estrutura pública de regulação com a criação da Secretaria Especial do Meio Ambiente (SEMA) pelo Decreto n. ${ }^{\circ}$ 73.030. Já em 1981, foi criado o Sistema Nacional de Meio Ambiente (SISNAMA), sendo este o responsável pela proteção e melhoria da qualidade ambiental, e estabelecido pela Lei 6.938, que institui a Política Nacional do Meio Ambiente (PNMA), tendo como principais instrumentos em seu Art. $9^{\circ}$, o de Zoneamento Ecológico Econômico (ZEE) para planejar o desenvolvimento do território e o de Avaliação de Impactos Ambientais (AIA). O Conselho Nacional do Meio Ambiente (CONAMA) também foi instituído pela Lei 6.938/81, definido como um órgão consultivo e deliberativo do SISNAMA. Ambos passaram a ser classificados como os principais instrumentos da política ambiental orientados para ações descentralizadoras.

O SISNAMA é composto por duas esferas políticas, uma de formulação de políticas onde se enquadram o CONAMA e o MMA, sendo um órgão superior do sistema e um central, respectivamente; e outro da esfera de execução de políticas onde o IBAMA se enquadra como executor da política nacional do meio ambiente em todos os órgãos setoriais, municipais e estaduais (MORAES; TUROLLA, 2004).

Em 1989, a SEMA, SUDEPE, SUDEHVEA e IBDF foram extintas, transformando-se no Instituto Brasileiro do Meio Ambiente e dos Recursos Naturais (IBAMA) (Lei 7.735/1989) assumindo as responsabilidades pelas ações antes estabelecidas ao SEMA, como a fiscalização das atividades causadoras de impactos ambientais.

A constituição federal traz em seu art. 225, a importância do meio ambiente ecologicamente equilibrado e de uso comum do povo. Esta preocupação ecológica estende-se para a instituição de Leis, esta sancionada um ano após a criação da Carta Magna, em 1989, a Lei de $\mathrm{n}^{\mathrm{o}}$ 9605, que dispõe sobre a penalidade para aqueles que cometem "Crimes Ambientais", fortalecendo, assim, os instrumentos de Direito Ambiental.

Outro marco para a história da política ambiental no Brasil foi a criação do Ministério do Meio Ambiente (MMA), por meio da Lei 8.490/1992, que assumiu a coordenação do 
PNMA, sendo responsável pela definição de objetivos, metas e políticas ambientais para o País.

As crescentes discussões mundiais sobre as questões voltadas ao meio ambiente e sustentabilidade, geraram na década de 90 , a preocupação com relação à necessidade de modificação e a implementação de novos modelos sustentáveis, ocasionando assim a unificação de diversos países à procura de debater as questões ambientais, assumindo assim o compromisso e o desafio de internalizar, em suas políticas públicas, as noções de sustentabilidade e de desenvolvimento sustentável. Com isso, surgiu a II Conferência das Nações Unidas sobre Meio Ambiente e Desenvolvimento (RIO 92), repercutindo diretamente na política ambiental dos países mundiais (NOVAES et al., 2000).

A RIO 92 trouxe a ampliação da visão sobre os problemas e as soluções ambientais, contribuindo para a participação de Organizações Não Governamentais (ONG's) e setor privado. Como resultado, investimentos foram aplicados em questões voltadas ao meio ambiente nos anos seguintes, dentre outros (NOVAES et al., 2000).

Após a RIO'92, o Brasil aprimorou a legislação ambiental com a aprovação da Lei 9.985/2000, instituindo o Sistema Nacional de Unidades de Conservação da Natureza (SNUC), que divide as Unidades de Conservação em Unidades de Proteção Integral (UPI) e Unidades de Uso Sustentável (UUS). Dez anos mais tarde surgiu em 2002 a Agenda 21, cuja finalidade era "compatibilizar a melhoria da qualidade de vida da população, proporcionando o crescimento econômico em sintonia com o meio ambiente" (SENADO FEDERAL, 2001).

\subsection{PLANEJAMENTO NAS BACIAS HIDROGRÁFICAS}

\subsubsection{DEFINIÇÕES E CONCEITOS}

Santos e Leal (2012) apresentam o planejamento, como uma série de métodos e processos, os quais a integração de dados e informações, com metas previamente definidas, possibilita a elaboração de um diagnóstico do território planejado, para assim propor ações que permitam seu uso adequado e a proteção contra impactos ou degradação do meio.

Ainda, de acordo com Santos e Leal (2012), o planejamento é um processo contínuo, que envolve decisões ou escolhas, com o objetivo de alcançar metas em prováveis momentos no futuro, utilizando modos alternativos de recursos disponíveis, agindo dentro do contexto e 
não isoladamente, tendo como resultados um melhor aproveitamento do espaço físico e dos recursos naturais, sem economia de tempo, de energia e dos recursos hídricos.

Silva (2003) os principais pontos do planejamento pari-passo:

"a tomada de decisão ou escolha envolvendo as envolvendo as diversas maneiras alternativas, e qual a melhor para se alcançar os mesmos objetivos; o uso ou alocação de recursos, que podem ser naturais, humanos, financeiros ou de infraestrutura; os caminhos alternativos para alcançar as metas traçadas, envolvendo metas realísticas, decisões políticas e participação popular; e, finalmente, planejando para o futuro, que envolve prognóstico ou previsões aproximadas do que pode acontecer e, mais especificamente, previsão dos resultados das alternativas propostas, que determina qual delas deverá ser adotada".

\subsubsection{PLANEJAMENTO URBANO E AMBIENTAL}

A partir da década de 70, o número populacional nos grandes centros passou a crescer desenfreadamente, devido ao crescimento industrial, ocasionando redução populacional nas zonas rurais. Por outro lado, nesses locais, há um intenso desenvolvimento na mecanização destinada às agroindústrias, causando um cenário de intenso contraste e conflitos entre a área urbana e rural no Brasil (PEIXOTO, 2005; SILVA; WERLE, 2007; PUSSININI, 2011; SANTOS; LEAL, 2012).

Os autores Silva \& Werle (2007) relataram que conforme a realidade atual no Brasil e no mundo, crescem novas e possíveis respostas para a busca de um processo de desenvolvimento mais equilibrado com o meio ambiente. Surgindo, desta forma, o planejamento como forma de premeditação dos efeitos e consequências do desenvolvimento urbano.

O planejamento é considerado um instrumento fundamental para amenizar os problemas decorrentes da disponibilidade e qualidade dos recursos naturais em bacias hidrográficas como também para atingir sua gestão adequada, que garanta o uso múltiplo destes recursos.

A Constituição de 1988 demostra ser um marco para o planejamento, o seu Art. 182 apresenta diretrizes que visam ordenar as funções sociais da cidade, além de garantir o bemestar da população.

Os temas voltados à sustentabilidade em países desenvolvidos tornaram-se frequentes, influenciando o Brasil e o mundo, surgindo, assim, diversos modelos e conceitos, como: o 
Plano de Gestão Ambiental (PGA), o monitoramento e gestão dos recursos naturais, as atividades antrópicas e suas interferências no meio ambiente, o conceito de ecologia e paisagem urbana, o licenciamento ambiental, a adoção de critérios para a utilização de fontes renováveis de energia e dos recursos naturais, associados ao Estudo de Impacto Ambiental (EIA) e Relatório de Impacto Ambiental (RIMA) (SILVA; WERLE, 2007). Sendo assim, o planejamento urbano atual se apresenta vinculado ao processo de planejamento ambiental e suas ferramentas legais.

Faz parte dos objetivos do planejamento ambiental garantir as condições ecológicas para o desenvolvimento efetivo da produção social, e todas as atividades da população, por meio do uso racional e da proteção dos recursos do meio ambiente. (PEIXOTO, 2005; NOVAIS, 2011).

Segundo Tucci (1997) os impactos apresentados na literatura decorrentes do desenvolvimento da expansão urbana sobre os processos hidrológicos são diversos, contudo Tucci (1997) relata que estão ligados à forma de ocupação do solo e também ao uso dele transformando suas superfícies em áreas impermeáveis em grande parte das bacias que estão inseridas em perímetro urbano.

Desta forma, para Tucci, (1997), as bacias que sofrem influência do perímetro urbano precisam de maiores cuidados, sendo que a qualidade desta deve ser levada em consideração devido a ações desenvolvidas ao longo do tempo para que estejam preservadas no futuro. Contudo, a ausência de planejamento adequado e a falta de monitoramento ocasionam ocupações desordenadas dificultando a efetividade desta tarefa.

\subsubsection{OCUPAÇÃO URBANA}

De acordo com Tucci(1997):

\footnotetext{
"O crescimento populacional e a densificação de fatores como a poluição doméstica e industrial se agravaram, criando condições ambientais inadequadas, propiciando o desenvolvimento de doenças de veiculação hídrica, poluição do ar e sonora, aumento de temperatura, contaminação da água subterrânea entre outros. Esse processo que se agravou principalmente à partir do final da década de 60 , mostrou que o desenvolvimento urbano sem qualquer ordenamento territorial resulta em prejuízos significativos para sociedade e para o meio ambiente".
}

Atualmente existem várias abordagens e contextualizações sobre o que é o Ordenamento Territorial: transformação ótima do espaço; política de planejamento físico com 
viés regional; ciência, abrangendo método de análise e modelagem de território cuja prática seria o planejamento territorial (MINISTÉRIO DA INTEGRAÇÃO NACIONAL, 2005).

A Carta Magna em 1988 definiu como direito da União á elaboração e execução de planos nacionais e regionais com a finalidade de promover o ordenamento territorial, sendo atribuído aos municípios o dever de planejar e controlar o uso e ocupação do local a fim de que seja promovido o ordenamento do território em questão (PERES; CHIQUITO, 2012).

Após a promulgação da Constituição de 1988, que tem em seu Art. 21, inciso IX a afirmação de que o PNOT tem o objetivo de elaborar e executar planos nacionais e regionais de ordenamento territorial e de desenvolvimento econômico e social. A Constituição, ainda, colocou o ordenamento territorial como um instrumento de planejamento, elemento de organização e de ampliação da racionalidade espacial das ações do Estado. Contudo, somente após quinze anos (2003), o PNOT é discutido e ainda está em tramitação (RÜCKERT, 2007).

O PNOT é importante para a conectividade entre as diferentes instruções normativas no âmbito do uso, ocupação e proteção do solo urbano e rural que, apesar de estarem relacionadas não são observadas, o que gera redundância ou conflitos. Dessa forma, espera-se a partir do PNOT a unicidade das normas legais referentes ao ordenamento territorial, que por se tratar de uma temática interdisciplinar necessita de uma integração não somente entre as normas dos entes federativos (políticas nacionais e locais), como também entre diferentes matérias, como é o caso de normas ligadas ao meio ambiente e promoção do desenvolvimento urbano e rural (BRASIL, 2006).

A partir da década de 90 o Brasil apresentou intenso desenvolvimento nas legislações e questões voltadas para o ordenamento e planejamento territorial. A Figura 3 apresentamos momentos de maior repercussão na gestão territorial do país (BRASIL, 2006; PERES; CHIQUITO, 2012). 


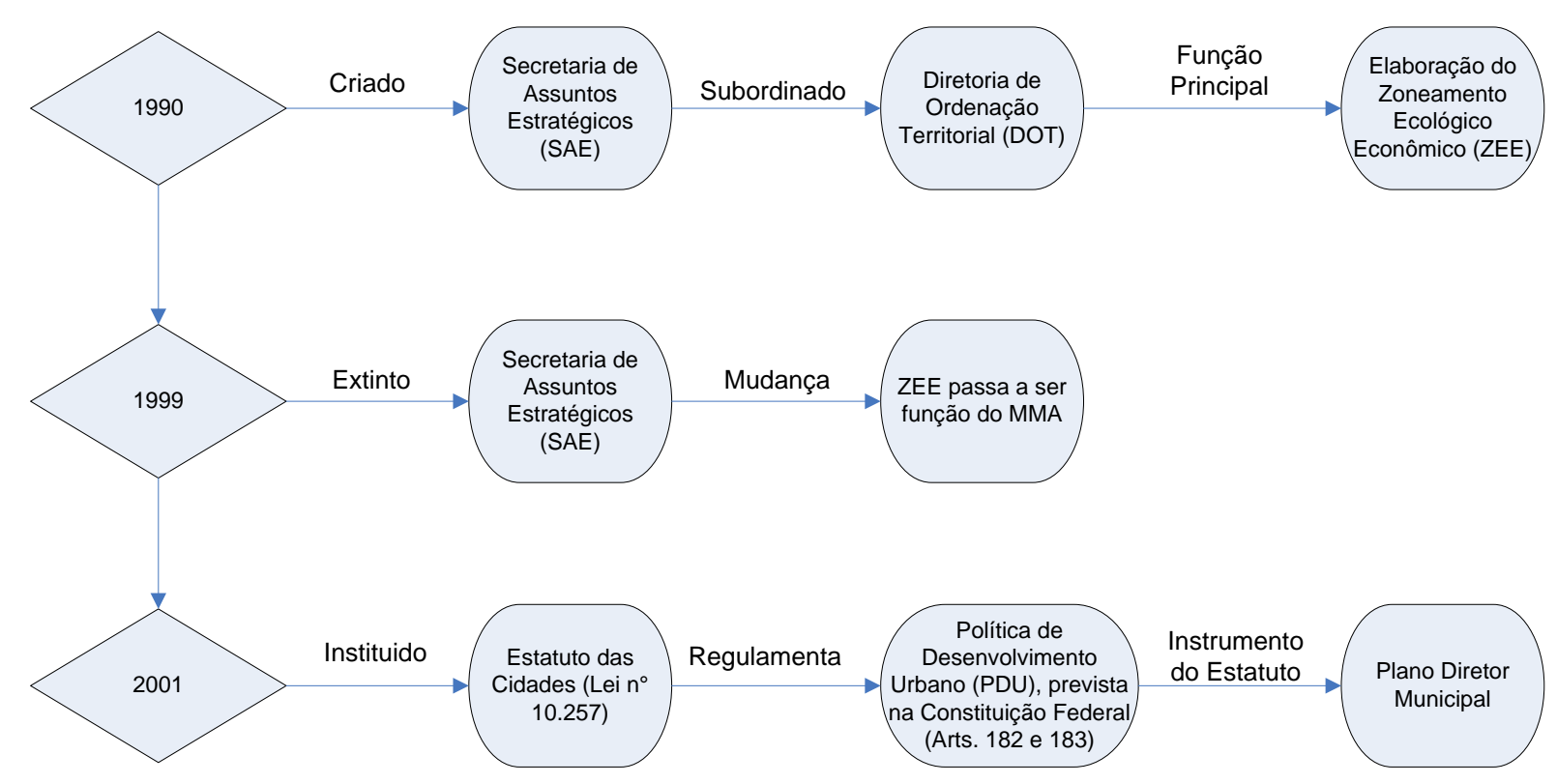

Figura 3: Histórico legislativo do planejamento e ordenamento urbano no Brasil

O Zoneamento Ecológico Econômico (ZEE) é um instrumento da PNMA, e peça fundamental para o ordenamento territorial, seu objetivo é subsidiar as ações de planejamento, de modo a otimizar o uso do espaço e promover o desenvolvimento sustentável neste, a partir das condições socioambientais existentes (GDF, 2015). O zoneamento é executado de forma partilhada pela União, os estados e os municípios. Cabe aos estados elaborar o ZEE em âmbito estadual, em conformidade com os zoneamentos de âmbito nacional e regional, a aos municípios a elaboração do plano diretor, utilizando como base os ZEE's existentes (MMA, 2015).

Dá-se destaque também ao Estatuto das Cidades que tem como objetivo "ordenar o pleno desenvolvimento das funções sociais da cidade e da propriedade urbana". Apresentando assim o Plano Diretor Municipal como instrumento do Estatuto das Cidades, tendo como objetivo principal o exercício das funções sociais da cidade a partir da regulamentação do uso urbano. Este dispositivo é obrigatório para cidades com mais de vinte mil habitantes (NUNES, 2014).

Existem ainda diversas legislações no Brasil, referentes ao Ordenamento Territorial, como apresenta a Figura 4, que, embora sejam específicas, também auxiliam no controle e monitoramento do uso e ocupação do solo, fazendo parte do grupo de ordenamento e planejamento territorial do país. 


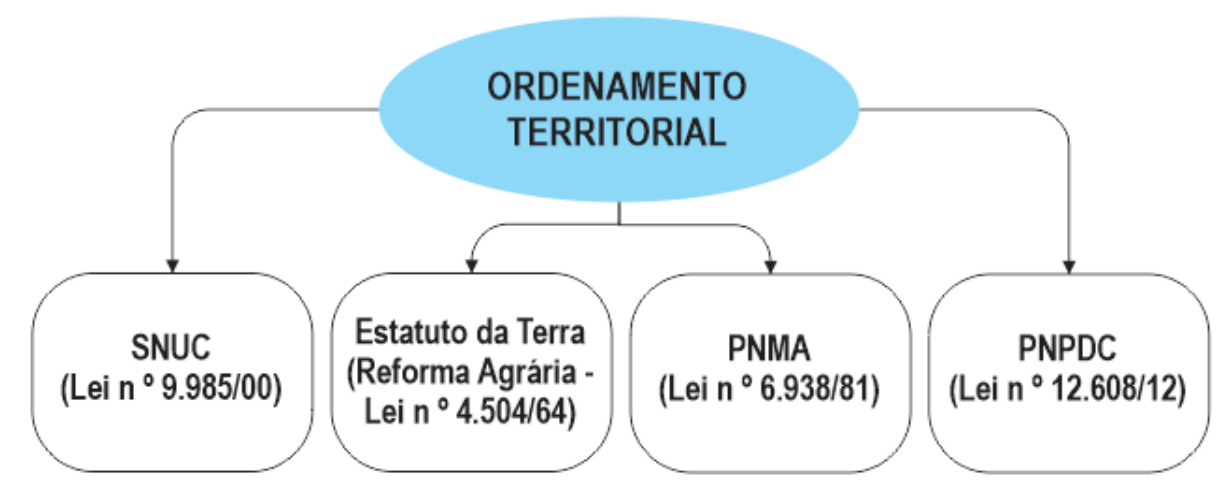

Figura 4: Legislações auxiliares ao ordenamento territorial brasileiro.

\subsubsection{PLANO DIRETOR DE ORDENAMENTO TERRITORIAL DO DISTRITO FEDERAL (PDOT/DF)}

A Lei Orgânica (Art. 316) definiu no Distrito Federal os instrumentos básicos das políticas de ordenamento territorial e desenvolvimento urbano como sendo: o PDOT e os Planos Diretores Locais (PDL's). Conforme a Secretaria de Estado de Gestão do Território e Habitação(SEDHAB, 2015) o PDOT é um "instrumento básico da politica territorial e de orientação aos agentes públicos e privados que atuam na produção e gestão das localidades urbanas, de extensão urbana e rural do território do Distrito Federal".

Anteriormente ao PDOT, o DF possuiu outras políticas de ordenamento territorial como o Plano de Estruturação e Organização Territorial do Distrito Federal (PEOT) homologado pelo Decreto n. ${ }^{\circ} 4.049 / 1977$ sendo a primeira medida administrativa concreta com o foco em ordenamento territorial. Já em 1985, surge o Plano de Ocupação Territorial (POT) e o Plano de Ocupação e Uso do solo (POUSO) aprovado em 1986 e homologado em 1990, vale relembrar que apenas o PDOT encontra-se em vigor

Em 1992 surge a primeira versão do PDOT pela Lei complementar n. ${ }^{\circ}$ 353, consolidando as diretrizes firmadas por todos os planos anteriores Figura 5. E em 1997, foi homologada a segunda lei complementar referente ao PDOT atual, pela Lei n. ${ }^{\circ} 17$ e em 2009, após longo período de discussões e já recepcionando o Estatuto das Cidades, foi sancionada a revisão do PDOT de 1997 (Lei complementar n. ${ }^{\circ}$ 803/2009). Por fim, em 2012 a Lei complementar $n .^{\circ} 854$ foi homologada, atualizando a Lei Complementar $n .^{\circ} 803$ que aprova a revisão do PDOT. Sendo assim, o PDOT do Distrito Federal em vigor é composto pelas Leis 
complementares $\quad \mathrm{n}^{\circ} \quad 803 / 2009 \quad$ e $\quad$ n. $^{\circ}$ 854/2012 (SEDHAB, 2014).

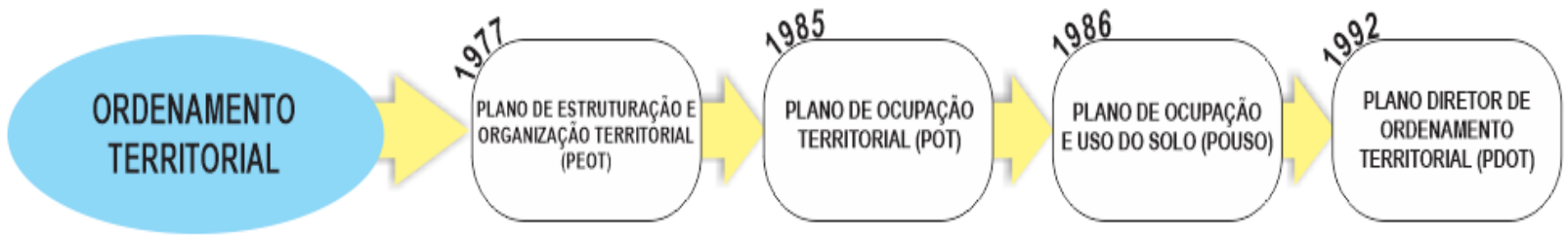

Figura 5: Histórico do ordenamento territorial

Dentre os objetivos do PDOT estão a melhoria da qualidade de vida da população, o resguardo do patrimônio ambiental, otimização do desenvolvimento urbano e rural de acordo com a infraestrutura e disponibilidade de serviços a fim de manter tal uso dentro de uma gestão participativa com a sociedade civil (SEDHAB, 2014, 2015). Sendo assim, o PDOT trata de diretrizes diversas como esgotamento sanitário e resíduos sólidos, transporte, e não somente acerca do uso e ocupação do solo (NUNES, 2014).

O PDOT ainda classifica as áreas urbanas de acordo com a densidade populacional, coeficiente de aproveitamento (área construída em relação a área do terreno), tamanho dos lotes disponibilizados e porcentagem de equipamentos urbanos(FREITAS, 2007). Nunes(2014) relata que a partir dessa setorização são determinadas restrições para cada área urbana a fim de traçar tendências de expansão, consolidação e de contenção na transição de áreas rurais em áreas urbanas, evitando assim criação de novos núcleos urbanos dissociados dos núcleos já existentes.

\subsection{INSTRUMENTOS DE AVALIAÇÃO AMBIENTAL}

\subsubsection{ESTUDO DE IMPACTOS AMBIENTAIS (EIA) E RELATÓRIO DE IMPACTOS AMBIENTAIS (RIMA)}

O Estudo de Impactos Ambientais (EIA) e Relatório de Impactos Ambientais (RIMA) são instrumentos de avaliação de impactos instituído no Brasil, dentro da Política Nacional de Meio Ambiente por meio da Resolução do Conselho Nacional do Meio Ambiente CONAMA.

Com isso, em 1986, através da Resolução $n^{\circ} .001$ do CONAMA institui-se critérios básicos para elaboração do EIA/RIMA, como ferramentas essenciais para o licenciamento de projetos de médio e grande porte, sendo de origem pública ou privada, cuja as atividades 
sejam classificadas como poluidoras ou degradadoras do meio ambiente. Sendo assim, o EIA/RIMA passou a instituir um conjunto de procedimentos designados a analisar os efeitos dos impactos ambientais de um determinado projeto, a sua influência e forma de aplicação como parte necessária para obtenção do licenciamento, bem como para a implantação e operação das atividades (SILVA; WERLE, 2007).

A Constituição Federal de 1988, em seu artigo 225, elevou a importância da realização do EIA, incumbindo o Poder Público a exigir, na forma da lei, o estudo prévio de impacto ambiental. No decorrer da dinâmica de mudanças nos espaços urbanos e rurais, o EIA, serve como instrumento de ordenação territorial. Este define uma mudança profunda na visão de se planejar espaços e projetos, sejam eles industriais, comerciais, turísticos, rodoviários etc.

Segundo Silva; Werle, (2007), o EIA deve ser entendido como uma ferramenta não somente legal, mas, indissociável do procedimento de planejamento e de projeto, pois a análise ambiental é, antes de tudo, a compreensão das possíveis mudanças de características socioeconômicas, biológicas e geofísicas de um determinado local, a partir dos resultados de um plano proposto. Para tanto, segundo o artigo $5^{\circ}$ da Resolução CONAMA nº 001/1986, o EIA propõe que quatro diretrizes sejam primeiramente entendidas, a fim de que depois se faça um estudo e uma avaliação mais específica. Sendo eles:

I. Desenvolver uma compreensão daquilo que está sendo proposto, o que será feito e o tipo de material usado;

II. Compreender o ambiente afetado como um todo, e qual ambiente (biogeofísico e/ou sócio econômico) será modificado pela ação;

III. Prever possíveis impactos no ambiente e quantificar as mudanças, projetando a proposta para o futuro;e

IV. Divulgar os resultados do estudo para que possam ser utilizados no processo de tomada de decisão.

\subsubsection{CÓDIGO FLORESTAL}

Os últimos cincos anos antes da publicação do novo código florestal foi marcado de intensos debates no governo, comunidade acadêmica, ambientalistas, ruralistas e no Congresso Nacional sobre a mudança na legislação florestal. A partir de maio de 2012, o Brasil passou a contar com um novo código florestal, gerador de polêmicas e conflitos entre pesquisadores, ambientalistas e ruralistas. 
O Código Florestal Brasileiro foi criado em 1934 (Decreto 23.793), que dentre outras medidas, obrigava os proprietários a preservar $25 \%$ da área de suas terras com a cobertura vegetal original, este decreto foi revogado em 15 de Setembro de 1965 através da Lei nº. 4.771 que definiu de forma minuciosa os princípios necessários para proteger o meio ambiente e garantir o bem estar da população do país, tendo como foco as Áreas de Preservação Permanente (APP) e as Reservas Legais (RL). Já em 1996, o código passou a ser modificado por diversas Medidas Provisórias, principalmente pela de $n^{\circ}$ 2.166-67/2001, até ser totalmente reformulado em Outubro de 2012.

O Instituto Nacional de Pesquisas Espaciais (INPE) apurou somente em 2001 um dos maiores índices de desmatamento do bioma da Amazônia, onde por meio da Medida Provisória $\mathrm{n}^{\circ}$ 2.166-67/2001, buscava se ampliar a proteção das florestas, entendendo-se que seria importante expandir as áreas de preservação previstas no Código de 1965, e as de Reserva Legal, cujo percentual foi ampliado para 80\%, na propriedade rural situada em área de floresta localizada na Amazônia, mas no Cerrado dentro da Amazônia Legal, reduziu de $50 \%$ para $35 \%$, entre outras alterações (ALENCAR et al., 2004).

Ainda conforme Alencar et al.(2004), a cada ano e a cada novo dado divulgado, os governos anunciam medidas de caráter emergencial para combater o desmatamento. No entanto, essas medidas, quase sempre de caráter normativo e superestrutural, têm sido insuficientes para reverter a perversa tendência histórica. No início de 2003, o INPE divulgou o dado referente ao ano de 2001, de cerca de 18 mil km² desmatados, muito acima dos 15 mil $\mathrm{km}^{2}$ estimados um ano antes, e também divulgou a estimativa de $21 \mathrm{mil} \mathrm{km}^{2}$ para 2002, um recorde histórico superado apenas pelo índice de 1995, de 25 mil km².

Os dados do INPE apuraram um valor de aproximadamente $5.843 \mathrm{~km}^{2}$ de desmatamento na Amazônia no ano de 2013, este valor foi superior ao ano subsequente (2012), cujo valor estimado foi de $4.571 \mathrm{~km}^{2}$. Apesar do aumento no desmatamento em 2013 , este é o segundo valor mais baixo da história, sendo sancionado a nova Lei o Novo Código Florestal (NCF) (Lei n $\left.{ }^{\circ} 12.651 / 2012\right)$.

Para a sanção da referida Lei Federal n 12.651/2012, o Governo Federal realizou 12 vetos e 32 mudanças, sendo que, dessas mudanças, 13 são ajustes ou adequações de conteúdo, 14 recuperam o texto do Senado e cinco são dispositivos novos (GARCIA, 2012).

O NCF, além de manter o estatuto das APP's e RL's, apresentou como novidade as diretrizes para recuperação dessas áreas alteradas, onde a cobertura vegetal foi convertida para 
outros usos da terra, devido á falta de fiscalização, assistência técnica, percepção de sua importância (COUTINHO et al., 2013).

Segundo a Sociedade Brasileira para o Progresso da Ciência (SILVA et al., 2012), o crescimento exponencial da irrigação, principalmente na década de 1980, fomentado pelo Programa Nacional de Aproveitamento Racional de Várzeas Irrigáveis (PRÓVÁRZEA), embora tenha possibilitado ampliar áreas de produção, gerou um grande passivo ambiental, por ocupar Áreas de Preservação Permanente (APPs), estabelecidas no Código Florestal de 1965. A Lei Federal n 12.651/2012 define as APP's e RL's, conforme os incisos II e III, do:

Art. $3^{\circ}[\ldots]$

II-Área de Preservação Permanente - APP: área protegida, coberta ou não por vegetação nativa, com a função ambiental de preservar os recursos hídricos, a paisagem, a estabilidade geológica e a biodiversidade, facilitar o fluxo gênico de fauna e flora, proteger o solo e assegurar o bem-estar das populações humanas.

III-Reserva Legal: área localizada no interior de uma propriedade ou posse rural, delimitada nos termos do art. 12, com a função de assegurar o uso econômico de modo sustentável dos recursos naturais do imóvel rural, auxiliar a conservação e a reabilitação dos processos ecológicos e promover a conservação da biodiversidade, bem como o abrigo e a proteção de fauna silvestre e da flora nativa.

Sendo tratados como prioridade no NCF, a existência e conservação das APP'S e RL's são de grande importância para o meio ambiente e principalmente para os recursos hídricos, ressalta-se que a vegetação constitui um papel importante no ciclo da água, pois é esta que auxilia na retenção e infiltração da água no solo através de suas raízes, contribuindo também com a atmosfera terrestre por meio dos processos de respiração e evapotranspiração. A remoção da vegetação desencadeia processos erosivos nas margens dos cursos d'água, acelera os processos de assoreamento e compromete o fluxo de escoamento, chegando a consequente redução a qualidade das águas, implicando na qualidade de vida da população. A existência de vegetação influencia também no equilíbrio do clima, segurança hídrica e secas, na proteção das bacias hidrográficas para o abastecimento de água, servem de abrigo para fauna silvestre, dentre outros (PUSSININI, 2011). 
Segundo Floresta, (2011), entre os diversos aspectos do NCF, pelo menos três geraram grande polêmica, entre a bancada ambientalista e lideranças ruralistas que defendem a nova reforma, também aprovada na Comissão Especial do Congresso, que são:

- Anistia aos crimes ambientais (supressão de vegetação nativa, poluição da água, solo e ar);

- Compensação de áreas desmatadas em um Estado por áreas de floresta em outros Estados ou bacias hidrográficas;

- Redução e descaracterização das APPs e RL's na Amazônia Legal;

O processo de discussão do NCF deve-se considerar a gestão integrada de território, dos recursos hídricos e proteção de solos, fundamentada no conhecimento científico. Assim como a reserva legal e as APPs, o meio ambiente e a agricultura do país têm funções e estruturas diferentes, mas complementares. Ambos são fundamentais para a geração de emprego, renda e produção de riqueza para o país. Trata-se de criar e de implementar mecanismos de incentivo à proteção, restauração e produção em bases sustentáveis (FLORESTA, 2011).

Os ambientalistas e profissionais da área ambiental são os principais opositores contra o $\mathrm{NCF}$, a nova proposta abrirá caminho para que muita área verde seja destruída e também que a flexibilização das Leis Ambientais vai favorecer grandes Fazendeiros interessados somente em lucro. A questão dos pequenos produtores não precisarem mais de manter uma reserva legal, por exemplo, vai fazer que muitos deles, movidos pela ganância acabem destruindo toda a área verde de suas propriedades, causando um forte desequilíbrio (VERONEZZI, 2011).

Os ambientalistas afirmam que apesar do Código Florestal Brasileiro ser rígido ele é adequado a nossa realidade já que o Brasil tem amplas reservas naturais e também uma grande biodiversidade (VERONEZZI, 2011).

\subsubsection{POLÍTICA NACIONAL DE RESÍDUOS SÓLIDOS}

O crescimento urbano, aliado ao desenvolvimento social e econômico, trouxe consigo o aumento da geração de resíduos urbanos no país e, consequentemente, o despertar para os problemas ambientais advindos deste progresso.

Nesse sentido, após mais de 20 anos de tramitação no Congresso, em agosto de 2010, instituiu-se a Política Nacional de Resíduos Sólidos (BRASIL, 2010), tornando-se um marco na busca pelo desenvolvimento sustentável do Brasil ao propor objetivos, princípios e diretrizes para a correta gestão e valorização dos resíduos. 
Dentre os objetivos da Política, pode-se destacar:

Art. $^{\circ} 7(\ldots)$

I - proteção da saúde pública e da qualidade ambiental;

II - não geração, redução, reutilização, reciclagem e tratamento dos resíduos sólidos, bem como disposição final ambientalmente adequada dos rejeitos;

III - estímulo à adoção de padrões sustentáveis de produção e consumo de bens e serviços; (...).

É possível destacar 3 (três) aspectos importantes da PNRS, apresentados a seguir:

- Responsabilidade Compartilhada;

- Planejamento de Gestão de Resíduos Sólidos;

- Produção e Consumo Sustentável.

Contudo mesmo com a instituição da lei, ainda existem obstáculos importantes quando o assunto se trata de resíduos sólidos. No Brasil, somente em 2013, a geração total de RSU foi de 76.387.200 toneladas segundo o Panorama dos Resíduos Sólidos no Brasil, desenvolvida pela Abrelpe (2013), representando um aumento de 4,1\%, índice que é superior à taxa de crescimento populacional no país no período, que foi de $3,7 \%$. Houve um aumento de $4,4 \%$ na quantidade de RSU coletados em 2013 relativamente a 2012. A comparação deste índice com o crescimento da geração de RSU mostra uma discreta evolução na cobertura dos serviços de coleta, chegando a 90,4\%, com um total de 69.064 .935 toneladas coletadas no ano.

A comparação entre a quantidade de RSU gerada e a coletada em 2013, mostra que diariamente mais de 20.000 toneladas deixaram de ser coletadas no país e, por consequência, tiveram destino impróprio, como, rio, lago ou mar, jogado em terreno baldio, enterrado ou queimado na propriedade.

De acordo com a PNRS, em seu Art. $3^{\circ}$, a destinação e disposição dos resíduos são consideradas adequadas quando:

(...)

VII - destinação de resíduos que inclui a reutilização, a reciclagem, a compostagem, a recuperação e o aproveitamento energético ou outras destinações admitidas pelos órgãos competentes, entre elas a disposição final, observando normas operacionais específicas de modo 
a evitar danos ou riscos à saúde pública e à segurança, e a minimizar os impactos ambientais adversos.

VIII - Disposição final ambientalmente adequada: distribuição ordenada de rejeitos em aterros, observando normas operacionais específicas de modo a evitar danos ou riscos à saúde pública e à segurança, e a minimizar os impactos ambientais adversos.

(...).

Só no Distrito Federal em 2013 foram coletados 1.578.990 toneladas de RSU, este índice subiu 5,74\% em comparação com ano anterior. A quantidade de RSU Coletado por habitante é o maior, quando comparado aos outros estados, chegando 1,551 kg/hab/dia, mesmo levando-se em consideração a redução de 3,1\% em relação ao ano de 2012.Ao se comparar a quantidade de resíduos gerados e coletados, cerca de 97 toneladas não são coletadas pelo sistema convencional de coleta, podendo seguir destinos inadequados(ABRELPE, 2013).

De acordo com Brasil, (2010) a PNRS prioriza a elaboração de um Plano Nacional de Resíduos Sólidos, pela União em coordenação com o Ministério do Meio Ambiente, tendo conteúdo mínimo:

(...)

III - metas de redução, reutilização, reciclagem, entre outras, com vistas a reduzir a quantidade de resíduos e rejeitos encaminhados para disposição final ambientalmente adequada;

V - metas para a eliminação e recuperação de lixões, associadas à inclusão social e à emancipação econômica de catadores de materiais reutilizáveis e recicláveis;

(...).

\subsection{SISTEMAS DE INFORMAÇÕES GEOGRÁFICAS (SIG) COMO APOIO PARA GESTÃO DE BACIAS HIDROGRÁFICAS}

O ser humano desenvolve ferramentas tecnológicas e sociais para atingir certo objetivo, para isso desenvolvem técnicas eficazes, de baixo custo e de fácil manuseio, a fim de que se possa promover a gestão da área em curto tempo ao longo dos anos. 
$\mathrm{Na}$ gestão ambiental uma das áreas ferramentas que mais cresce é baseada no Geoprocessamento, utilizando imagens de satélite e Sistemas de Informações Geográficas (SIG). Os programas de SIG ganharam seu espaço, sendo uma ferramenta essencial para análises de Ordenamento Territorial, Monitoramento de Queimadas e Desmatamento, Monitoramento de áreas protegidas legalmente, dentre outros (SÁ et al., 2010).

Com a utilização dos SIG's é possível realizar múltiplas análises, por meio da integração de dados geográficos. Os SIG'S permitem a integração de dados oriundos de diversas áreas da ciência como: sensoriamento remoto, cartografia, biologia, ciências sociais, geologia, entre outras, tendo como objetivo a representação de fenômenos do mundo real.

Diversos estudos foram desenvolvidos aplicando-se as técnicas de SIG na identificação dos conflitos em Bacias Hidrográficas. Em sua pesquisa Sá et al. (2010) utilizam um SIG, com a finalidade de analisar a gestão e o planejamento da Bacia Hidrográfica Vaca Brava (PB), observando como resultado de pesquisa, ausência no planejamento ambiental e urbano.

Faria \& Pedrosa, (2005) realizaram um diagnóstico da bacia hidrográfica do Rio Uíma - Portugal, identificando áreas críticas e destacando locais de conflito, e, sinalizando a possibilidade de determinar áreas de vulnerabilidade.

Pinto \& Garcia, (2005) propuseram a utilização de um SIG para realizar a caracterização física da bacia hidrográfica do Ribeirão Santa Cruz, analisando o cumprimento da legislação ambiental nas áreas de preservação permanentes dos córregos, nascentes e encostas. Os resultados mostraram que existe a necessidade de um plano de recomposição da vegetação das APPs em estudo, uma vez que os desmatamentos e outros usos incorretos dos solos podem refletir na quantidade e qualidade da água da bacia hidrográfica.

Zanata et al., (2011) utilizaram a ferramenta SIG, para analisar o uso e a ocupação do solo em Áreas de Preservação Permanente (APP) na micro bacia do Ribeirão Bonito/São Paulo. O estudo além de ressaltar os impactos presentes e comparar a situação atual com a legislação vigente, concluiu que as ferramentas de Geoprocessamento se mostraram eficientes no diagnóstico de problemas ambientais.

Os estudos citados demonstram que o uso de geoprocessamento pode auxiliar na tomada de decisões relacionadas ao planejamento ambiental e urbano como também na simulação de cenários futuros. 


\subsection{MODELOS DE APLICAÇÕES MULTIDICIPLINARES}

Pode-se encontrar na literatura nacional e internacional diversos modelos com aplicações multidisciplinares (análise de água, poluição atmosférica, poluição do solo, entre outros), no entanto será descrito o modelo de análise multicritério que pode ser aplicado a temas relacionados com a qualidade ambiental.

\subsubsection{Análise multicritério}

A partir da década de 70 foi desenvolvido por Tomas L. Saaty o método AHP (Analytic Hierarchy Process), um dos métodos multicritérios mais conhecido e utilizado no auxílio às tomadas de decisões mais complexas.

Este método auxilia de forma mais compreensiva a criação de hierarquias, critérios e metas. Após a criação da hierarquia, os responsáveis pela decisão podem avaliar sistematicamente seus elementos, por meio de comparações.

Segundo Costa (2004) o método AHP se baseia em três princípios do pensamento analítico:

I. Construção de hierarquias:

No AHP o problema é estruturado em níveis hierárquicos, como forma de buscar uma melhor compreensão e avaliação do mesmo. Na definição das hierarquias o nível 1 deve ser formado pelo objetivo principal, no caso da presente pesquisa medir o nível de qualidade ambiental da bacia do rio Melchior e o nível 2 e 3 formados pelos critérios e alternativas definidas pelo responsável pela pesquisa, ou seja, medir o nível de qualidade do meio físico e saneamento da bacia do rio Melchior (Figura 06). 


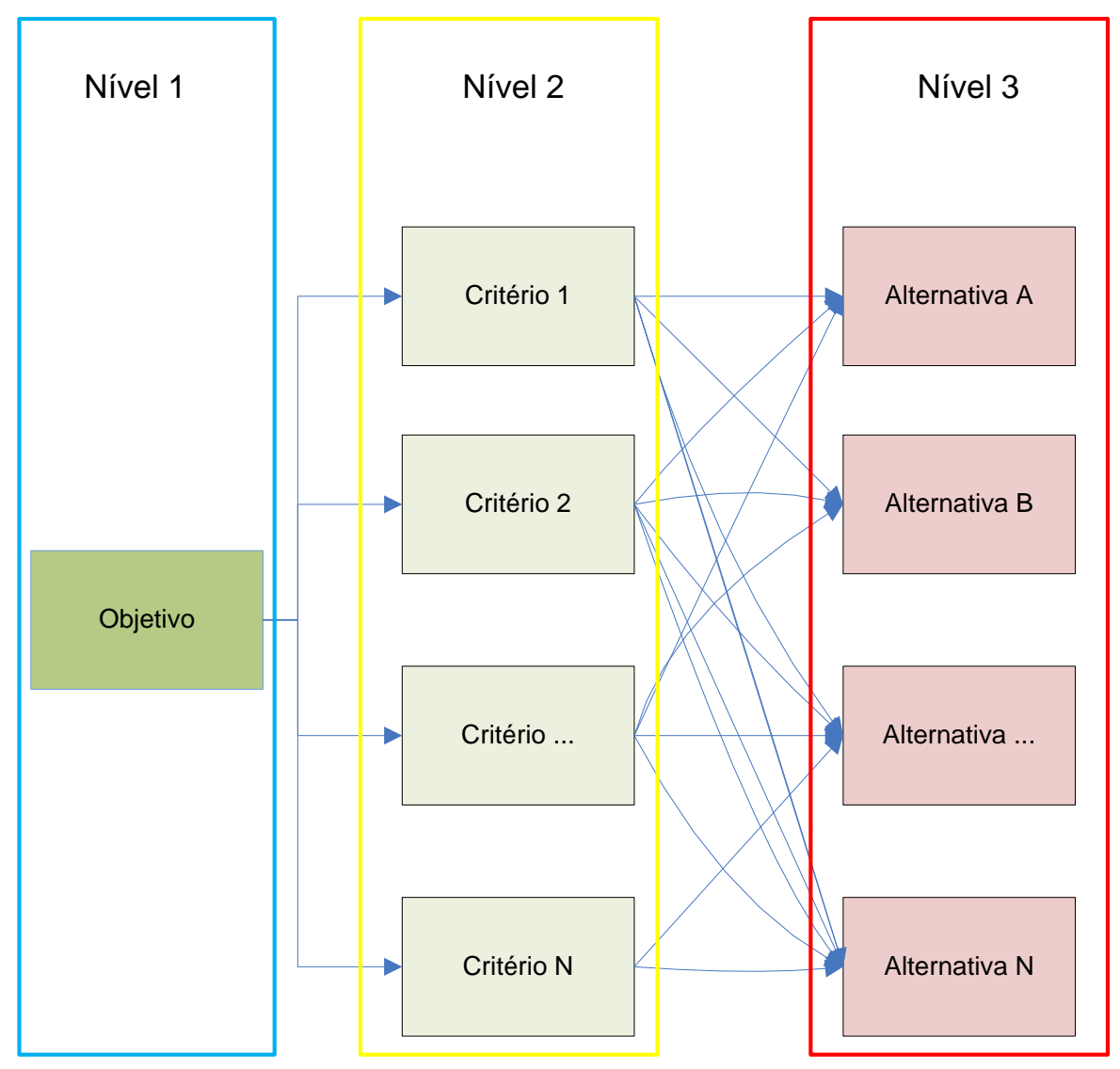

Figura 6: Estruturação hierárquica do AHP.

Ainda segundo Costa (2004), a construção de hierarquias é uma etapa fundamental do processo de raciocínio lógico. No exercício desta atividade identificam-se os elementos chave para a tomada de decisão, agrupando-os em conjuntos afins formando as alternativas.

\section{Definição de prioridades}

O ajuste das prioridades no AHP fundamenta-se na habilidade do ser humano de perceber o relacionamento entre os objetos e as situações observadas, comparando-as duas-aduas, à luz de um determinado foco, critério ou julgamentos paritários (COSTA, 2004).

Os critérios e alternativas de um mesmo nível são julgados duas-a-duas (Figura 7), e posteriormente a conexão desses elementos em um nível superior, compondo as matrizes de julgamento. 


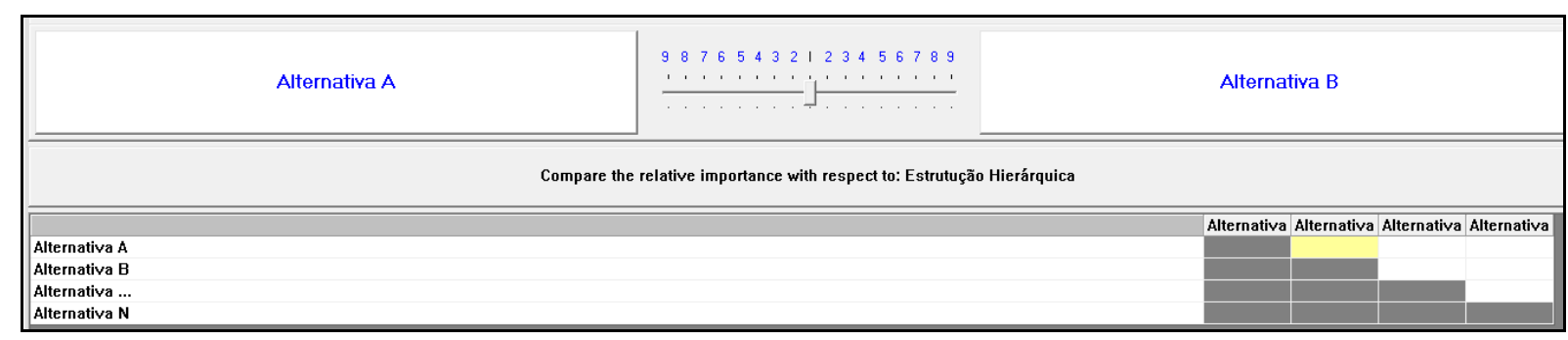

Figura 7: Julgamento em pares

Os pesos são definidos individualmente por cada pesquisador que participa da avaliação, obedecendo a hierarquia definida. A escala numérica de pesos varia de 1 a 9 , sendo que:

1 = Extra baixo, elementos são de igual importância;

2 = Muito baixo;

3 = Baixo, importância moderada de um elemento sobre o outro;

4 = Pouco baixo;

5 = Médio, forte importância de um elemento sobre o outro;

6 = Pouco alto;

7 = Alto, importância muito forte de um elemento sobre o outro;

$8=$ Muito alto;

$9=$ Extra alto, extrema importância de um elemento sobre o outro;

Segundo Marins et al. (2009) a quantidade de julgamentos necessários para a construção de uma matriz de julgamentos genérica A é n (n-1) /2, onde $n$ é o número de elementos pertencentes a esta matriz. Os elementos A são definidos pelas condições descritas na Equação 1:

$A=\left[\begin{array}{cccc}1 & a_{12} & \ldots & a_{1 n} \\ 1 / a_{21} & 1 & \ldots & a_{2 n} \\ \ldots & \ldots & \ldots & \ldots \\ 1 / a_{\pi 1} & 1 / a_{n 2} & \ldots & 1\end{array}\right]$

A normalização das matrizes de julgamento é dada pelo somatório dos elementos de cada coluna e posteriormente pela divisão de cada elemento pelo somatório dos valores de cada coluna.

\section{Consistência lógica}

Segundo Costa (2004) no AHP é possível avaliar a consistência do modelo de priorização construído. Essa avaliação é realizada pelo valor do índice de inconsistência, dado 
por IC $=(Y m a ́ x-n) /(n-1)$, onde Ýmáx é o maior autovalor da matriz de julgamentos (COSTA, 2004). De acordo com Saaty (1991) os valores tem que ser menores ou iguais a 0,10 para assegurar uma lógica racional no processo. Foi utilizado o Software Expert Choice versão 3.01 (EXPERT CHOICE RESOURCE ALIGNER, 2004) no auxilio do processo de julgamento e dos cálculos dos pesos atribuídos.

O Expert Choice utiliza ferramentas de colaboração de equipe e técnicas matemáticas que demostram a melhor decisão para atingir um objetivo. O processo de escolha permite:

- verificar a complexidade de estrutura;

- medir a importância dos objetivos, critérios e alternativas;

- $\quad$ sintetizar informações, conhecimentos e julgamentos;

- analisar a conduta hipotética e a sensibilidade;

- compartilhar resultados e iterar partes do processo de decisão, quando necessário;

- alocar recursos (se desejado).

Após a conclusão da escolha poderá ter uma decisão profunda, racional e compreensível que é intuitivamente atraente, e que podem ser comunicadas e justificadas (EXPERT CHOICE, 2015).

\subsection{SISTEMAS SENSORES}

Segundo Meneses e Almeida, (2012) o sensoriamento remoto teve sua origem nos anos de 1960 com o desenvolvimento da área espacial nessa década. Esse período apresentou o mais rápido desenvolvimento de foguetes lançadores de satélites. Os satélites meteorológicos foram os pioneiros e foi por meio deles que o sensoriamento remoto deu seus primeiros passos. A tabela 1 traz um breve histórico da evolução dos sistemas sensores que culminou na construção dos atuais sensores imageadores.

Tabela 1: Evolução dos sistemas sensores. Fonte: adaptação de Marinho., (2014)

\section{Data Fato histórico}

1964 Início do programa de satélites meteorológicos com lançamento do Nimbus-1.

1960’s Fotos espaciais dos projetos Gemini e Apollo. 
1972

Lançamento do ERTS-1 (renomeado posteriormente para Landsat-1) e fotos da Skylab, primeira estação espacial americana.

1975 Landsat-2 e GOES.

1977 Meteosat-1.

1978 Landsat-3, GOES-3, Nimbus-7 e Seasat, primeiro satélite civil com radar de abertura sintética.

1981 SIR-A (Space Shuttle Imagining Radar) e Meteosat-2.

1982 Landsat-4.

$1984 \quad$ SIR-B e landsat-5.

$1986 \quad$ SPOT-1.

1988 IRS-1 A, Meteosat-3 e Ofeq-1.

1989 Meteosat-4 e Ofeq-2.

$1990 \quad$ SPOT-2.

1991 ERS, IRS-1B e Meteosat-5.

1992 JERS-1 e Topex/Poseidon.

1993 SPOT-3, Meteosat-6 e Landsat-6 falha em atingir a orbita.

1994 SIR-C/X-SAR voa na spaceshuttle.

1995 OrbView-1, ERS-2, Radarsat-1, IRS-1C, falha no Ofeq-3 e satélite espião KH-12.

1996 IRS-P3 e falha no SPOT-3. Adeos-1 falha após 8 meses em operação.

1998 SPOT-4, SPIN-2 e JERS-1.

1999 Landsat7, IKONOS II, IRS-P4, QuickSCAT, CBERS-1, Terra, MODIS, ASTER, CERES, MISR, MOPITT e Kimpsat 1.

2000 SRTM, Tsinghau-1, EROS A1 (Israel) e Jason-1.

2001 Quickbird. 
Aqua, SPOT-5, ENVISAT, METSAT, Alsat-1, Meteosat Segunda Geração, ADEOS-II e Ofeq-5.

ICESat, Orbview-3, ALOS, Radarsat-2, CEBERS-2, DMC bilsat, DMC NigeriaSat-1 e DMC UK.

2004 RocSat2.

2005 TopSat, um micro-satelite, com 2.5m de resolução espacial e Cartosat.

2007 RapidEye e Worldview-1.

2009 Worldview-2.

2010 GeoEye.

2013 Landsat-8.

Segundo Marinho.(2014) os sensores imageadores são equipamentos eletro-ópticos mecânicos capazes de detectar e registrar a radiação eletromagnética em determinada faixa do espectro eletromagnético e gerar informações que possam ser transformadas em um produto passível de interpretação, na forma de imagens.

Os sensores imageadores podem ser classificados pela sua resolução espacial (Tabela 2), no presente trabalho, classificaram-se os sensores em resolução baixa, aqueles que têm resolução maior que $>30 \mathrm{~m}$, sensores de média resolução, aqueles com resolução entre $15 \mathrm{~m}>$ $30 \mathrm{~m}$, sensores de alta resolução, aqueles com resolução entre $1 \mathrm{~m}>15 \mathrm{~m}$ e sensores de altíssima resolução, aqueles inferiores a $<1 \mathrm{~m}$.

Tabela 2: Alguns Sensores imageadores conforme sua resolução espacial

\begin{tabular}{lllllll}
\hline & Satélite & País & Ano & Sensor & Resolução \\
\hline & IKONOS & USA & 1999 & PAN & $1 \mathrm{~m}$ \\
\hline
\end{tabular}




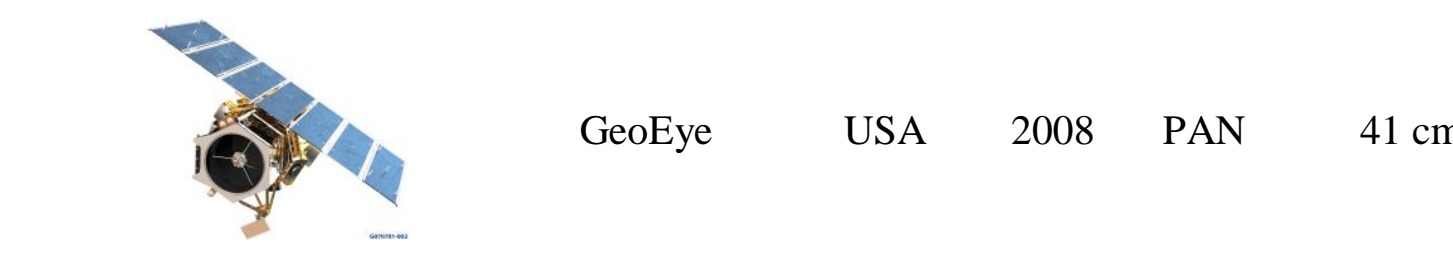

Worldview USA $2013 \quad$ PAN $\quad 50 \mathrm{~cm}$
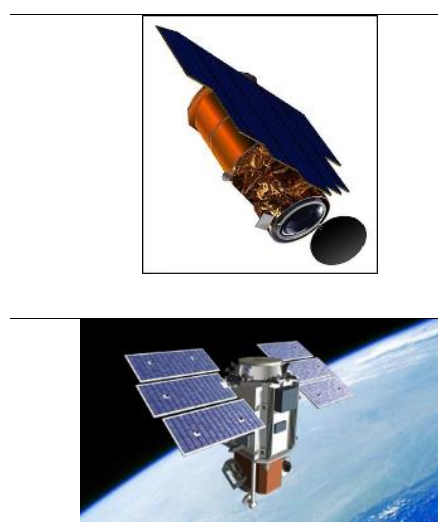

$$
\text { QUICKBIRD USA } 2001 \quad \text { PAN } \quad 60 \mathrm{~cm}
$$

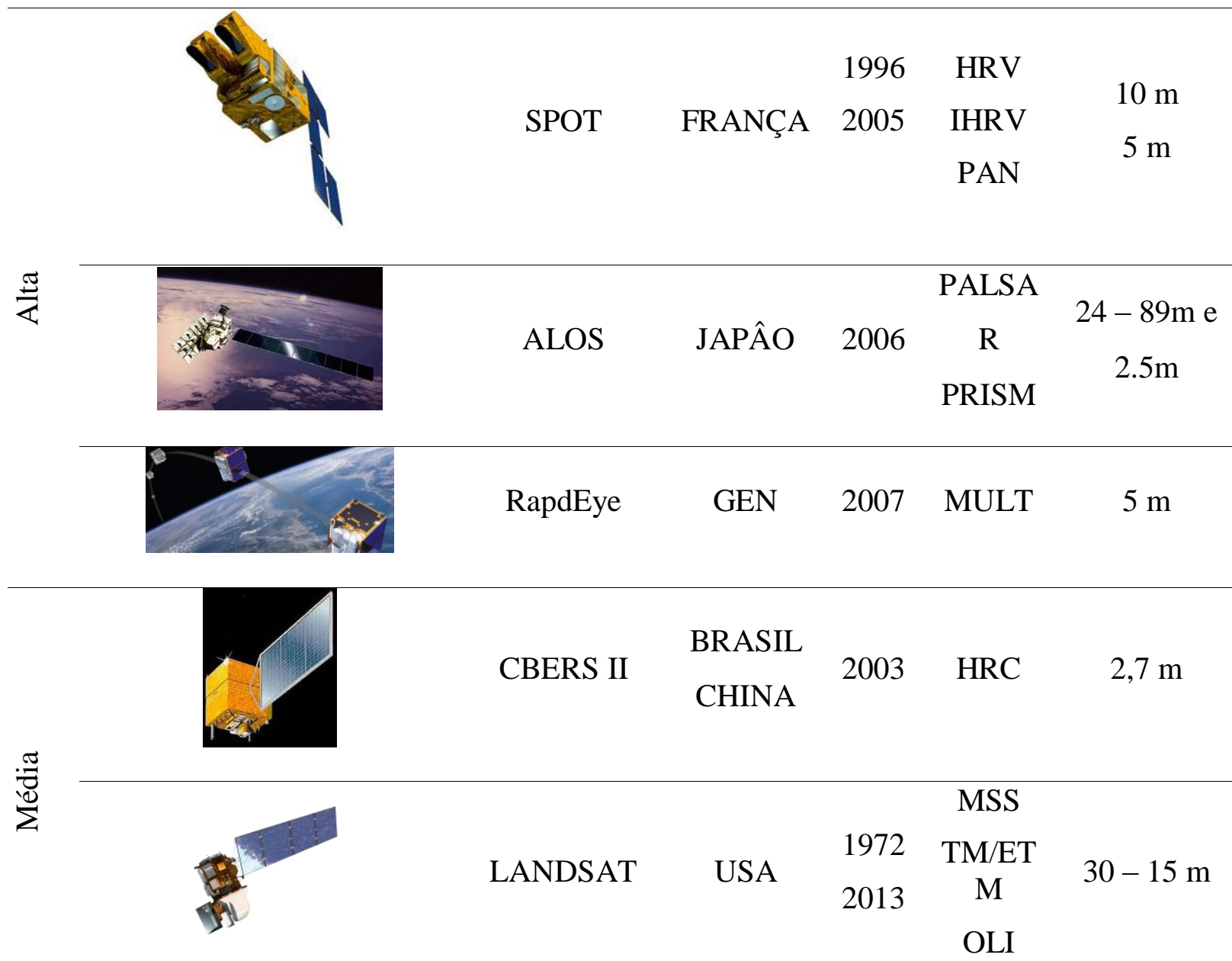




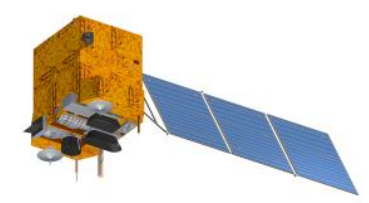

$\begin{array}{lllll} & \text { BRASIL } & 1999 & & \\ \text { CBERS I } & \text { CHINA } & 2007 & \text { CCD } & 20 \mathrm{~m}\end{array}$

\begin{tabular}{cccccc}
\hline & BRASIL & 1999 & IRMSS & $256 \mathrm{~m}$ \\
CBERS I & CHINA & 2007 & WFI & $78 \mathrm{~m}$ \\
& & & &
\end{tabular}

Pode-se destacar entre os sistemas imageadores o sistema RapidEye suas imagens foram adquiridas pelo Governo Federal Brasileiro, dentro de um programa do MMA para o monitoramento dos biomas. O sistema RapidEye é formado por uma constelação de cinco satélites de Sensoriamento Remoto, idênticos e posicionados em órbita síncrona com o Sol, com igual espaçamento entre cada satélite (Tabela 3). Cada um dos cinco satélites RapidEye efetua 15 voltas por dia em torno do planeta e os sensores a bordo dos satélites podem coletar imagens sobre a superfície da Terra ao longo de uma faixa de $77 \mathrm{~km}$ de largura por até 1500 km de extensão (FELIX et al., 2009).

Tabela 3: Síntese da consulta bibliográfica.

\begin{tabular}{|l|l|}
\hline Número de Satélites & 5 \\
\hline Altitude da Órbita & $630 \mathrm{~km}$, órbita síncrona com o Sol \\
\hline Hora de Passagem no Equador & $11: 00 \mathrm{hs}$ (aproximadamente) \\
\hline Velocidade & $27.000 \mathrm{~km} / \mathrm{h}$ \\
\hline Largura da Imagem & $77 \mathrm{~km}$ \\
\hline Tempo de Revisita & Diariamente (off-nadir); 5,5 Dias (nadir) \\
\hline Capacidade de Coleta & 4,5 milhões de Km2/dia \\
\hline Tipo do Sensor & Multiespectral (pushbroomimager) \\
\hline Bandas Espectrais & $5($ Red, Green, Blue, Red-Edge, Near IR) \\
\hline Resolução Espacial (nadir) & $6,5 \mathrm{~m}$ \\
\hline Tamanho do Pixel (ortorretificado) & $5 \mathrm{~m}$ \\
\hline Armazenamento de Dados a Bordo & $1.500 \mathrm{~km}$ de dados de imagens por órbita \\
\hline Resolução Radiométrica & $12 \mathrm{bits}$ \\
\hline Velocidade de Download (banda X) & $80 \mathrm{Mbps}$ \\
\hline
\end{tabular}

Fonte: (BRIDGE, 2015) 
Os cincos satélites são equipados com sensor multiespectral composto de scanners de linha, com 12.000 pixels cada, capaz de capturar imagens em cinco bandas espectrais, com alcance de comprimento de onde entre $440 \mu \mathrm{m}$ e $850 \mu \mathrm{m}$. A resolução de cada banda é de 5 metros (ortorretificado), resultando em imagens corrigidas com precisão de detalhes compatível com escala 1:25.000 (FELIX et al., 2009).

\section{Capítulo 2 - Materiais e Métodos}

\section{1 ÁREA DE ESTUDO}

O estudo foi realizado na bacia do Rio Melchior (Figura 8) localizado entre as longitudes $48^{\circ} 02^{\prime} 30^{\prime \prime} \mathrm{W}$, longitudes $48^{\circ} 15^{\prime} 21^{\prime \prime} \mathrm{W}$ e latitudes $15^{\circ} 48^{\prime} \mathrm{S}$, latitudes $15^{\circ} 55^{\prime} 17^{\prime \prime} \mathrm{S}$, ocupando uma área de $207,8 \mathrm{~km}^{2}$. O rio Melchior é formado a partir da confluência do Ribeirão Taguatinga com o Córrego do Valo e o Córrego Gatumé (Figura 9), entre as cidades satélites de Ceilândia e Samambaia, dentro da área de relevante interesse ecológico Juscelino Kubitscheck, a 983 metros de altitude. O rio Melchior, corre no sentido Nordeste-Sudoeste até desaguar no Rio Descoberto, percorrendo cerca de $30 \mathrm{Km}$. 

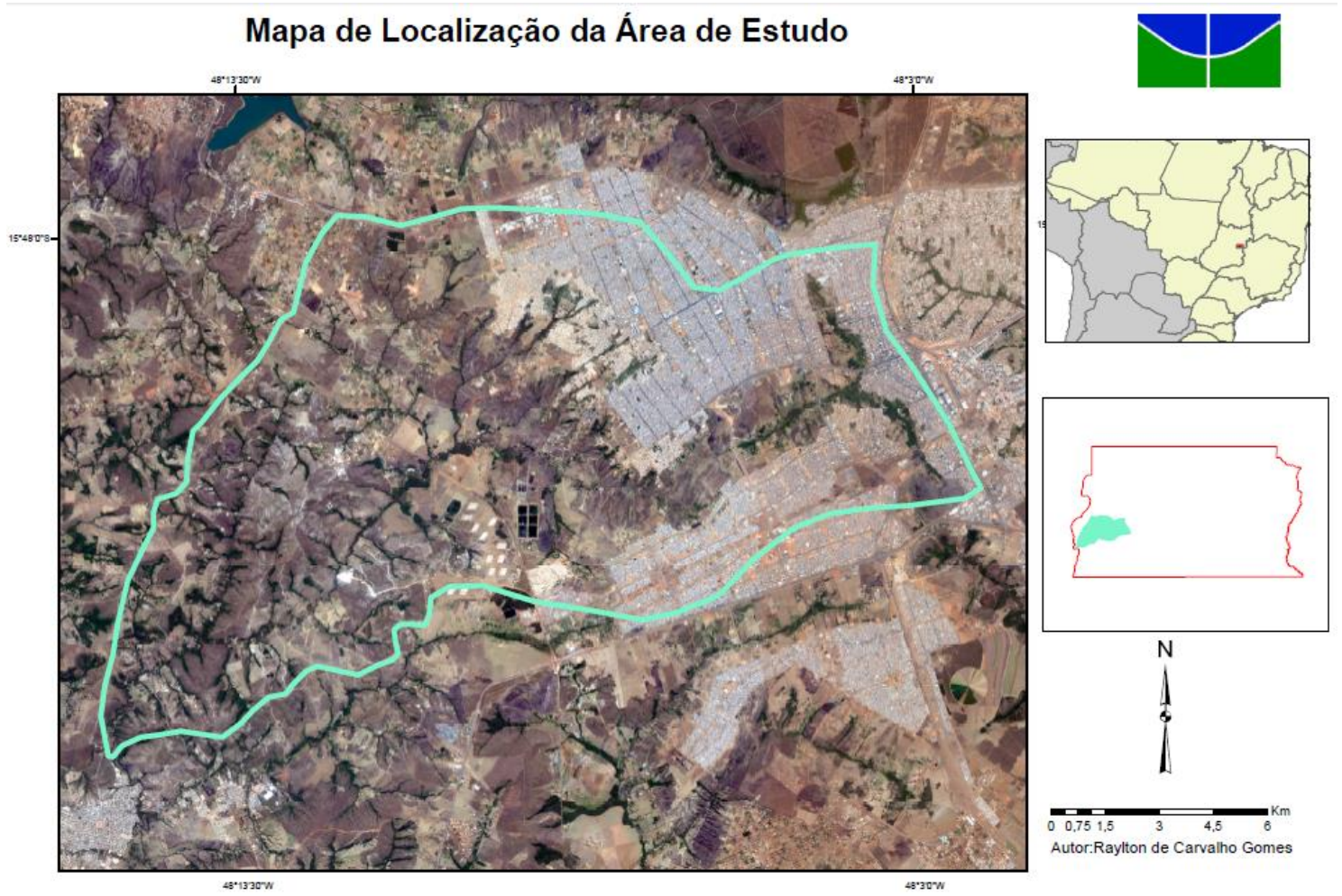

Autor:Raylton de Carvalho Gomes

Figura 8: Mapa de localização da área de estudo

\section{Mapa hidrográfico}
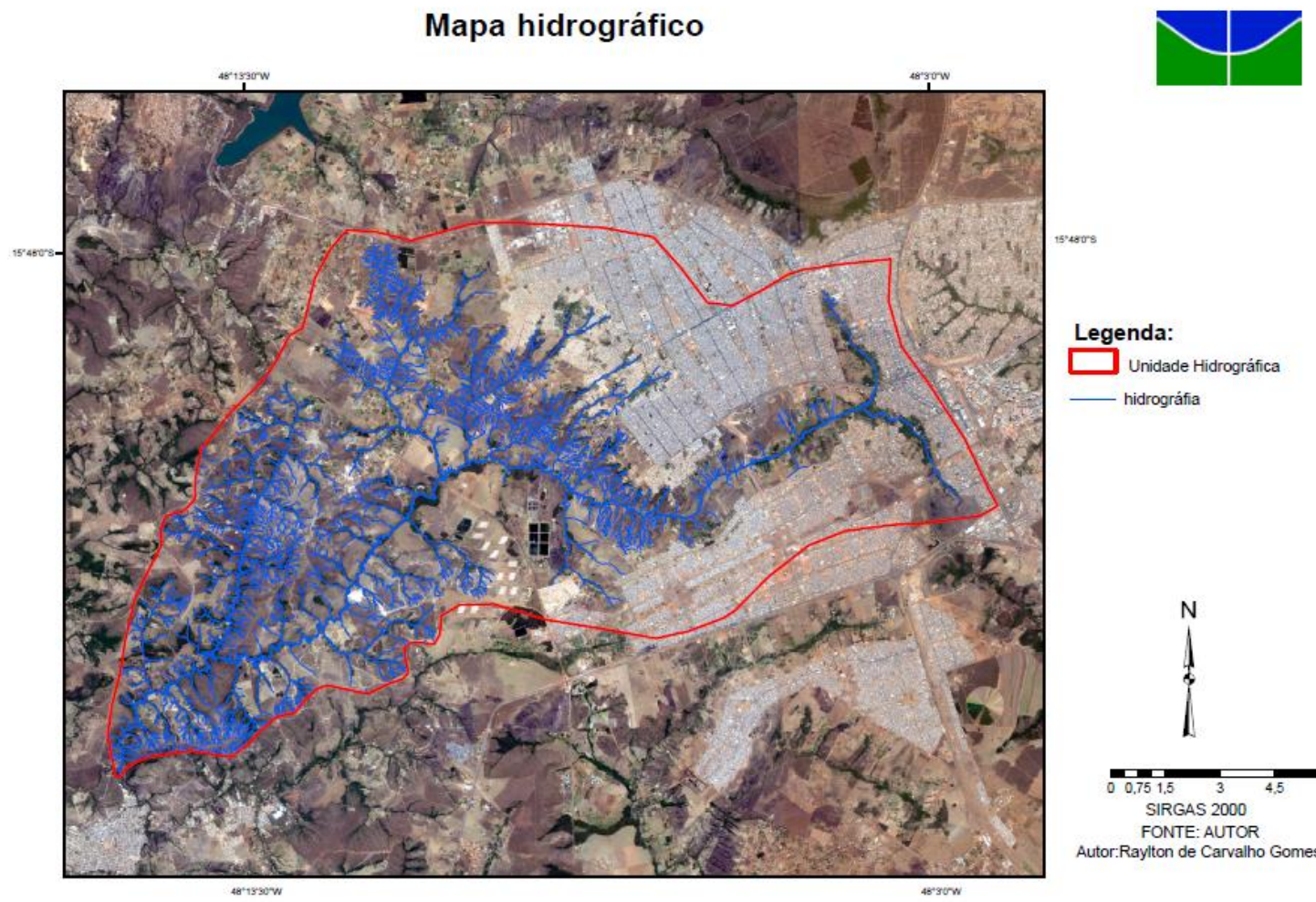

Legenda:

$\square$ Unidade Hidrográica

- hidrográfia

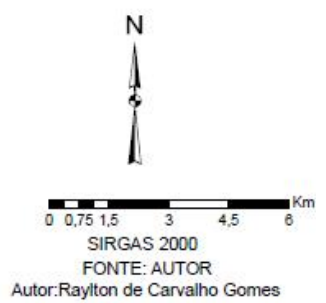

Figura 9: Mapa hidrográfico 


\subsection{MATERIAIS}

\subsubsection{IMAGEM}

Foi utilizada uma imagem RapidEye na elaboração do mapa de uso e ocupação do solo, obtidas por meio de uma parceria do MMA e o Instituto Geociências.

\subsubsection{PLUVIOSIDADE}

O mapa de isoietas foi desenvolvido por Gonçalves (2007), e gerado a partir de um banco de estações climatológicas e pluviômetros existentes no Distrito Federal, com dados coletados no período de 1960 a 2006, o mapa foi recortado e adaptado para bacia do Melchior utilizando o software ArcGIS 10.2.

\subsubsection{PEDOLOGIA}

O mapa pedológico foi desenvolvido pela Embrapa (2004a) e recortado para bacia do Melchior na escala de 1:100.000 utilizando o software ArcGis 10.2.

\subsubsection{DECLIVIDADE}

Na elaboração do mapa de declividade foi utilizada as curvas de nível da base de dados topográficos planialtimétricos do Sistema Cartográfico do Distrito Federal na escala original de 1:10.000 disponibilizado pela CODEPLAN.(1992).

\subsubsection{SANEAMENTO}

Para caracterização do saneamento residente na bacia Hidrográfica do Rio Melchior foi realizado o levantamento de dados junto ao censo demográfico 2010, do Instituto Brasileiro de Geografia e Estatística - IBGE.

Com base na necessidade de caracterização da população foram avaliados os indicadores de maior relevância para aferir o nível de qualidade da bacia, de acordo com a necessidade e o objetivo do estudo (Figura 10). 


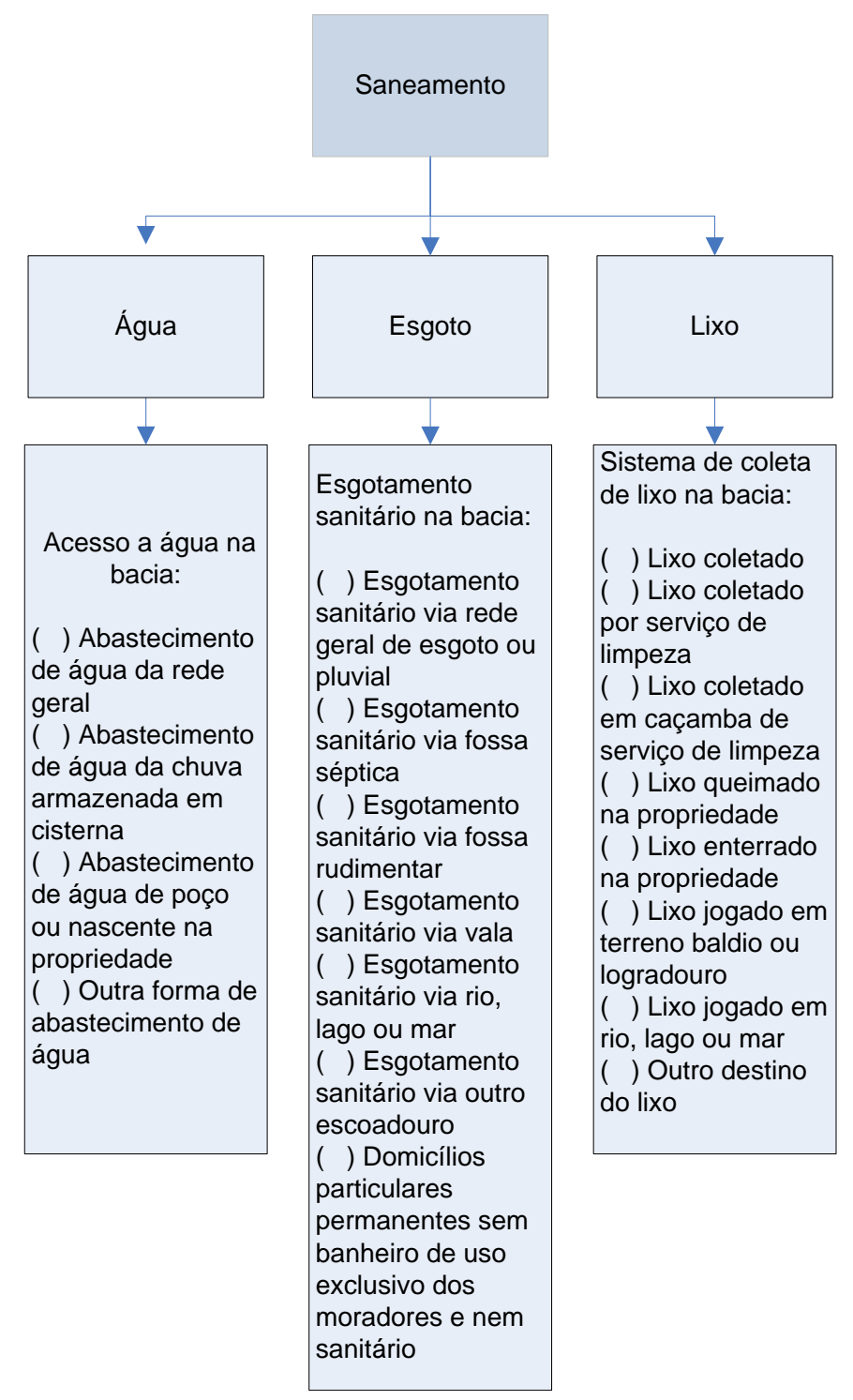

Figura 10: Rede hierárquica do levantamento do saneamento

\subsubsection{SOFTWARES}

Foram utilizados os seguintes programas computacionais para desenvolvimento da presente pesquisa:
a) ArcGIS 10.2
b) Expert Choice 11

\subsection{MÉTODOS}

Com base nas literaturas nacionais e internacionais (CONAMA, 1986; SCHIAVETTI;

CAMARGO, 2002; MACEDO, 2004; MARTINS et al., 2005; SÁNCHEZ, 2008; XAVIER, 2011; NOVAIS, 2011; SILVA; ZAIDAN, 2011; SHARAFI et al., 2012; BERNARDI et al., 
2013; REIS et al., 2013; ZHAO et al., 2013; ZHOU et al., 2014), foi desenvolvido um modelo para identificação do nível de qualidade ambiental da bacia hidrográfica do Melchior (Figura $11)$. 


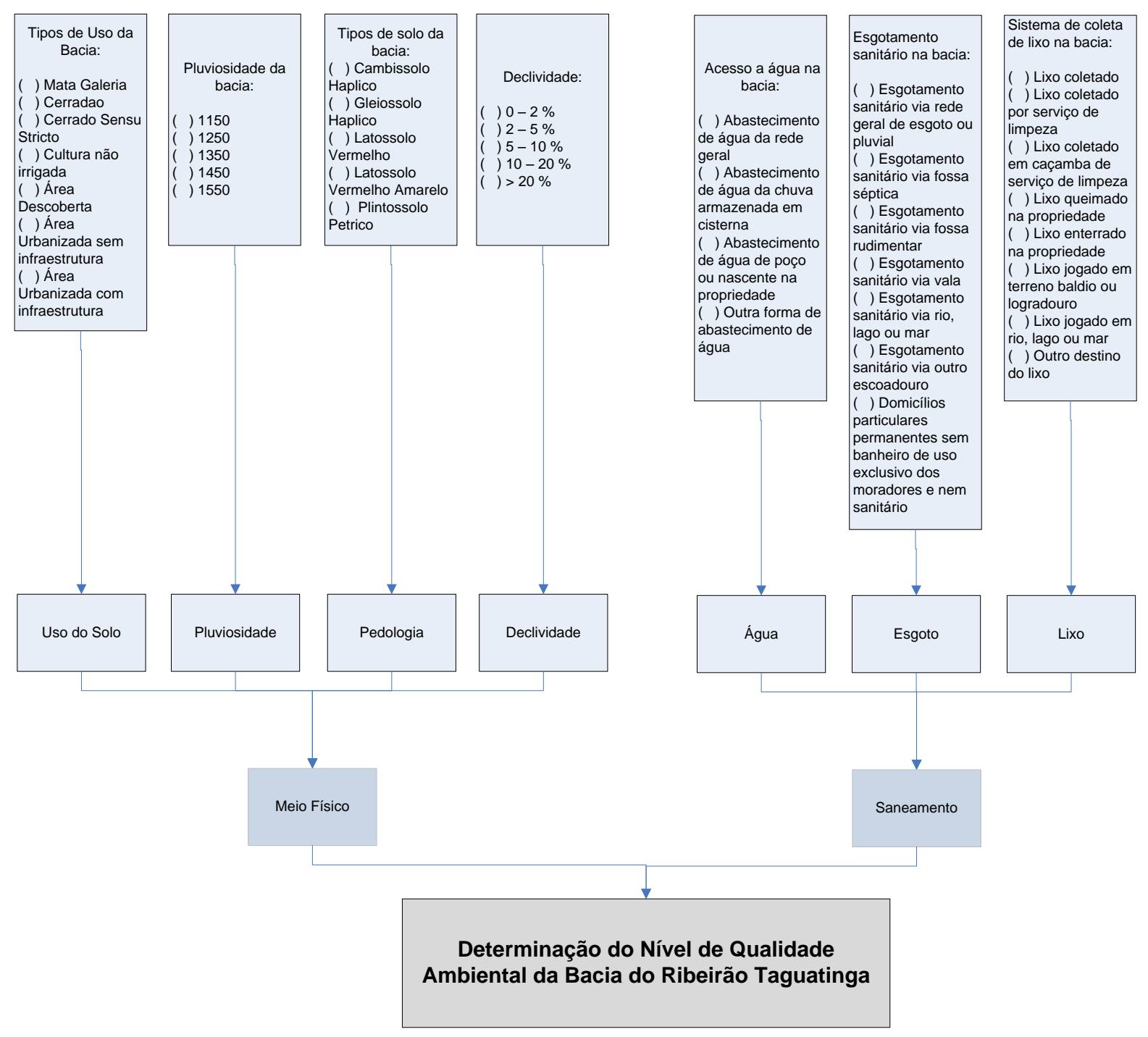

Figura 11: Modelo para identificação do nível de qualidade ambiental da bacia 
Após a definição do modelo e levando em consideração sua estrutura, sua aplicação seguiu a seguinte ordem (figura 12):

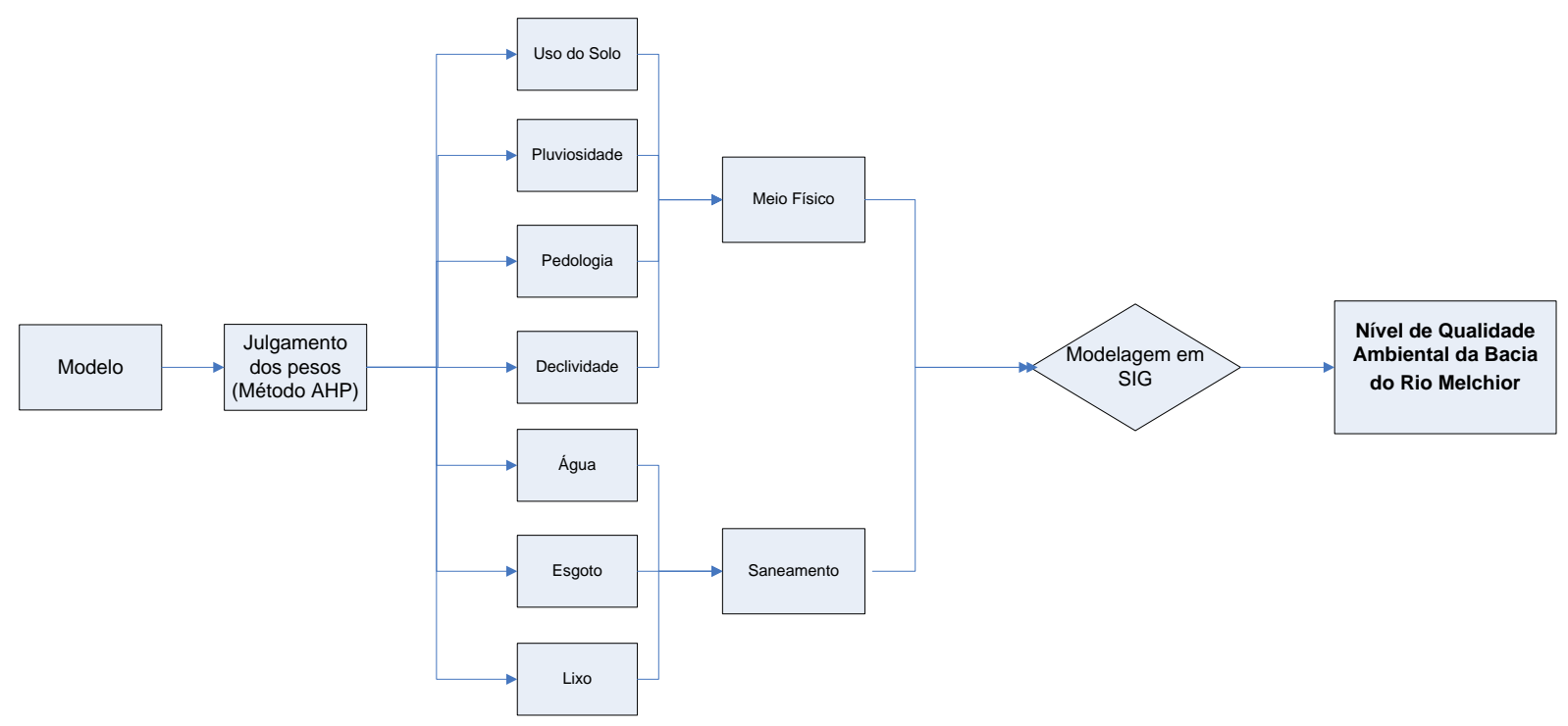

Figura 12: Aplicação do modelo

Os critérios elencados na figura 11 passaram por um processo de julgamento de pesos, sendo dividido em três etapas: na primeira etapa foram julgados os dados das subdivisões das divisões do meio físico e saneamento, na segunda etapa foram julgadas as subdivisões do meio físico e saneamento e já na terceira etapa foi julgado o meio físico e saneamento (Figura 13).

O julgamento dos pesos foi realizado, por 5 (cinco) pesquisadores da área de geoprocessamento e análise ambiental, em razão do tempo da pesquisa, e sobretudo da dificuldade de obtenção da disponibilidades de tempo dos demais pesquisadores contactados.

Esse julgamento foi realizado por meio do método multicritério Analytic Hierarchy Process (AHP) e em seguida, o resultado do julgamento passou por um processo de modelagem em SIG (figura 13). 


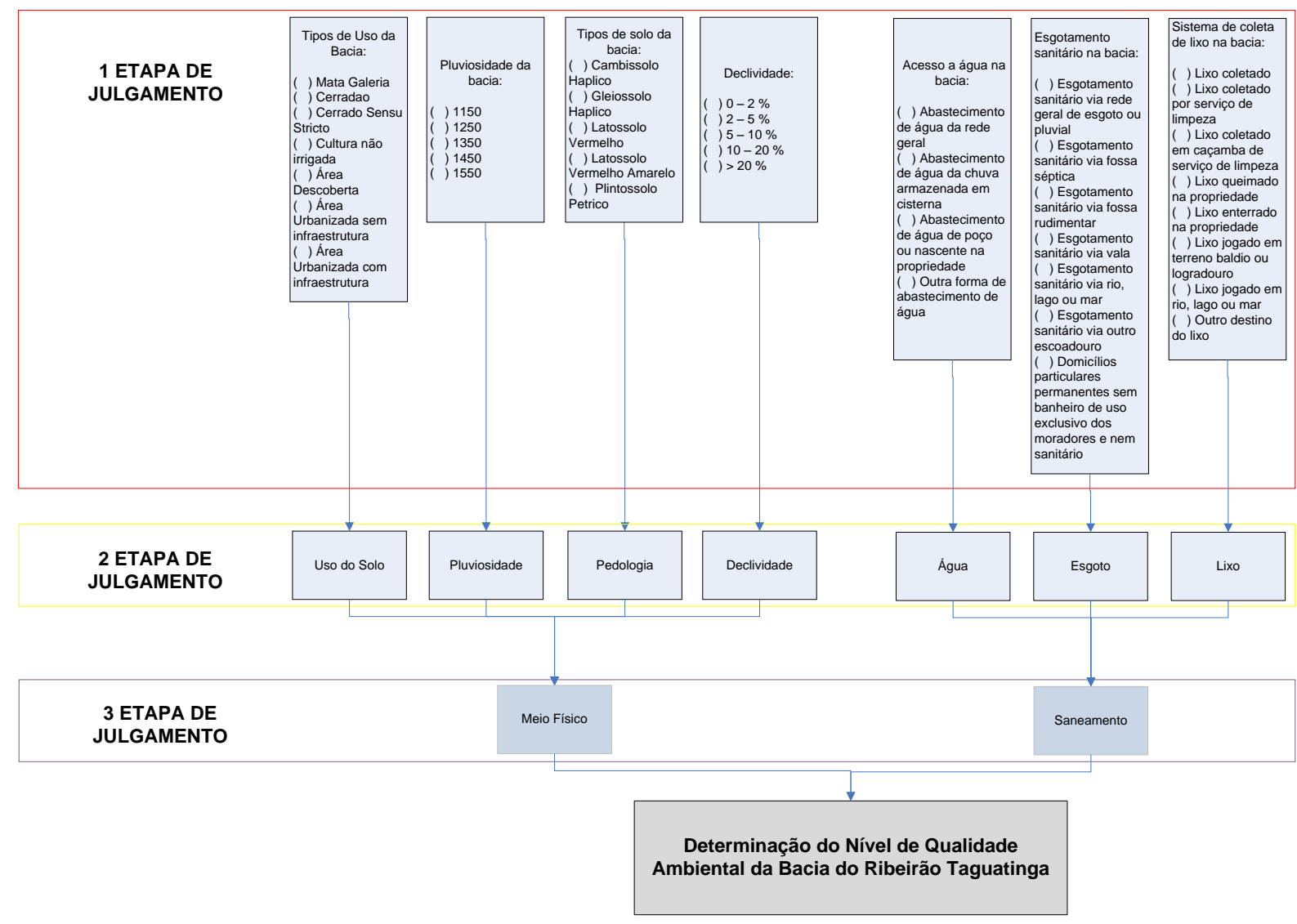

Figura 13: Etapas do processo de julgamento de peso

\subsubsection{MODELAGEM EM SIG}

Na elaboração do mapa do nível de qualidade ambiental da bacia do Melchior os mapas de declividade, classificação do uso do solo, pluviosidade, pedologia, água, esgoto e resíduos sólidos, foram convertidos para cobertura matricial e reclassificados conforme quadro 01, tendo por base os pesos que determinaram a influência de cada um dos elementos na análise da qualidade ambiental, ordenando os pesos definidos pelos pesquisadores. 


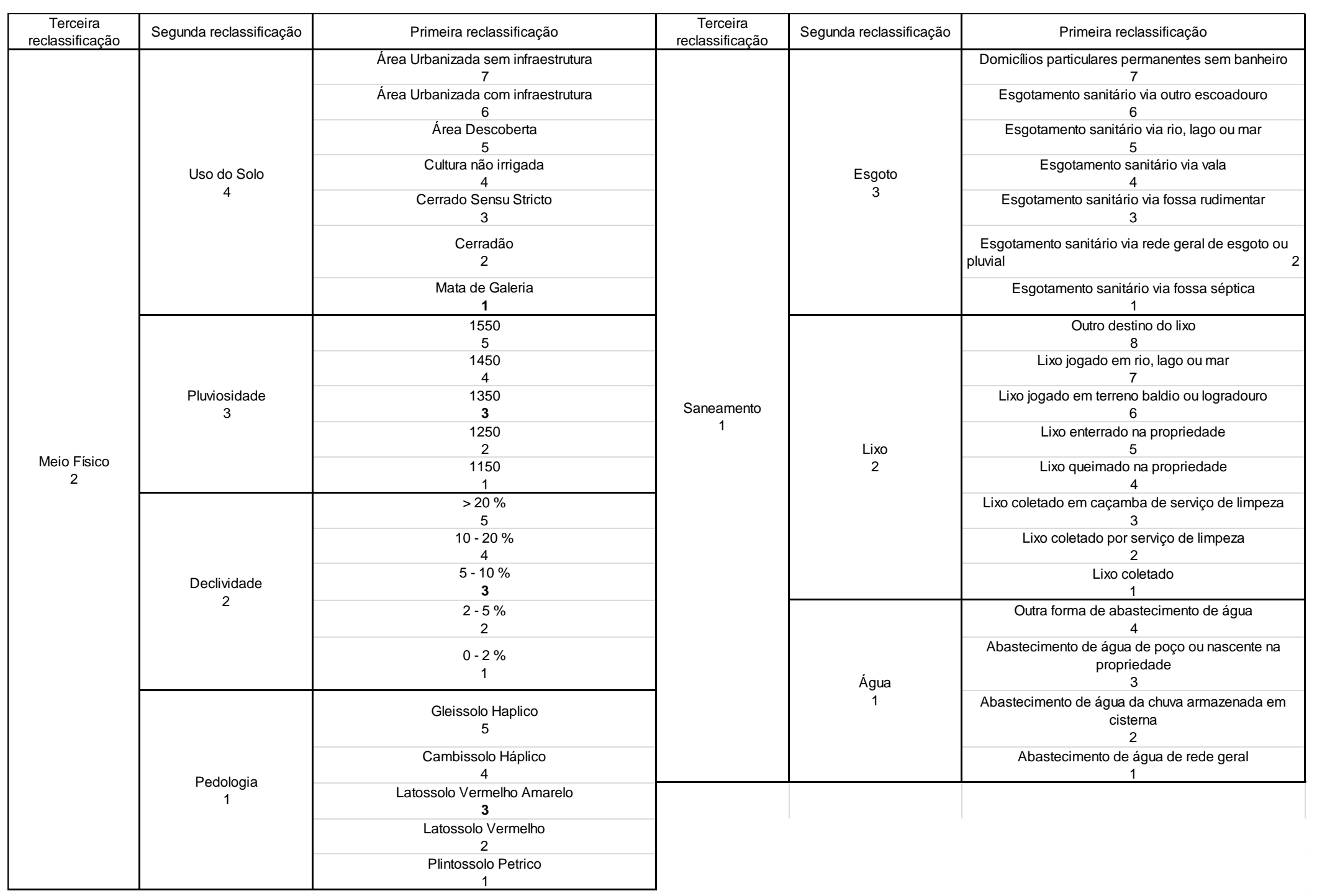

Quadro 1: Reclassificação dos critérios e alternativas do modelo. 
Após essa etapa os dados de classificação do uso do solo, pluviosidade, pedologia e declividade foram multiplicados pelos pesos, obtidos no processo de julgamento, e, depois, somados utilizando a ferramenta de álgebra matricial (ArcGIS 10.2), sendo assim gerado o Mapa de síntese do meio físico.

$\mathrm{Na}$ geração do Mapa de síntese do saneamento os dados reclassificados foram multiplicados pelos seus pesos e somados utilizando a ferramenta de álgebra matricial (ArcGIS 10.2).

Por fim, os mapas de síntese do meio físico e do saneamento, foram integrados por meio da ferramenta de álgebra matricial (ArcGIS 10.2) utilizando-se os pesos relativos, gerados pelo AHP gerando o Mapa do Nível de Qualidade Ambiental da Bacia do Melchior conforme figura 14 . 

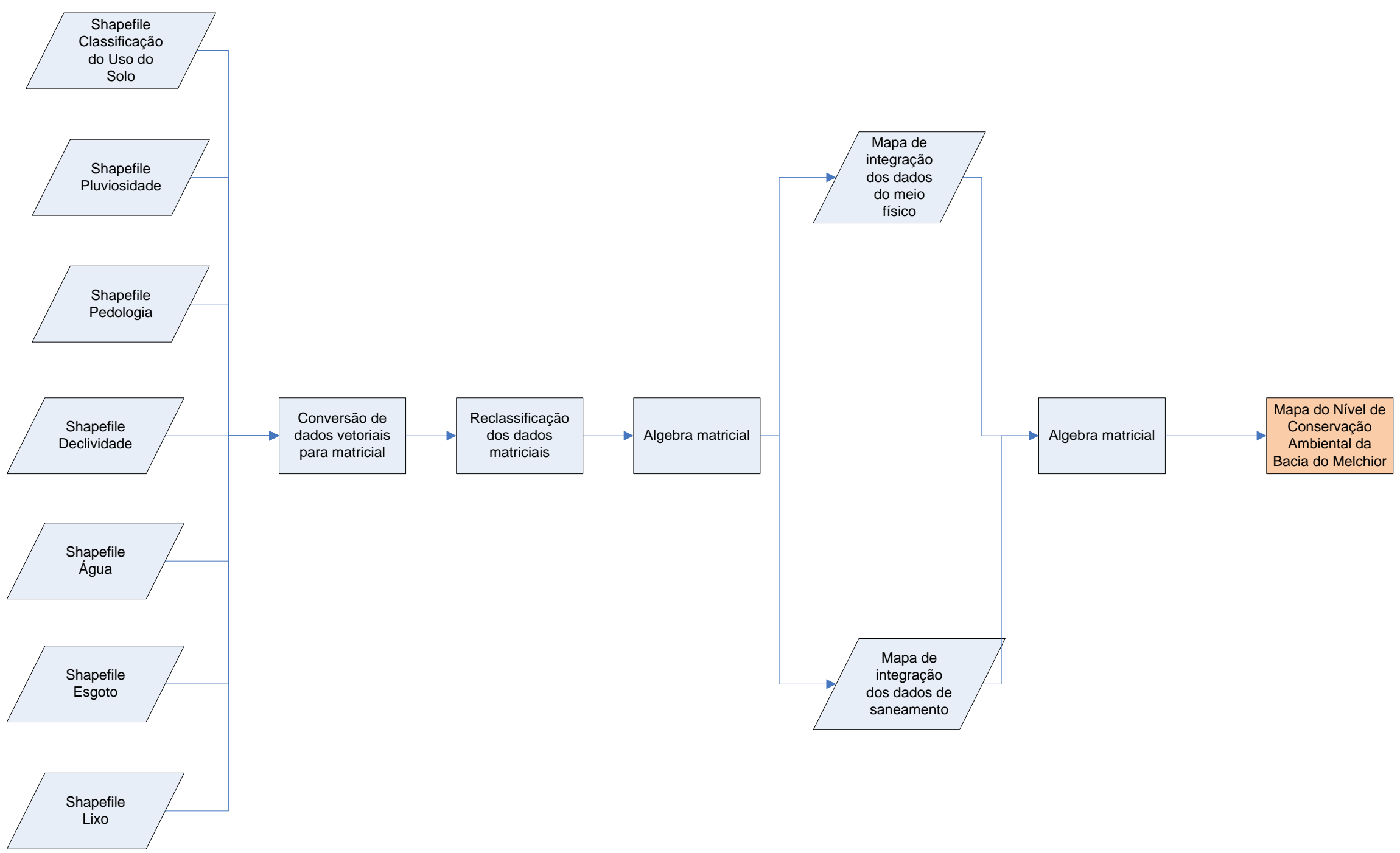

Figura 14: Modelagem em SIG 


\subsubsection{MEIO FÍSICO}

\subsubsection{Uso do Solo}

O mapa de uso e ocupação do solo foi executado em duas fases: modelo conceitual $1 \mathrm{e}$ modelo conceitual final. O modelo conceitual 1 (Figura 15) foi baseado nos critérios elaborados pelo IBGE (2013) e visa atender à classificação de uso e de ocupação de qualquer área. Vale ressaltar que o modelo conceitual 1 não é universal, devendo sofrer adaptações para cada aplicação.

Para atender o objetivo da pesquisa, fez-se necessário a adaptação do modelo conceitual 1 para a realidade da área em estudo, caracterizando-se, aqui, a segunda fase do trabalho, a elaboração do modelo conceitual final (Figura 16). 


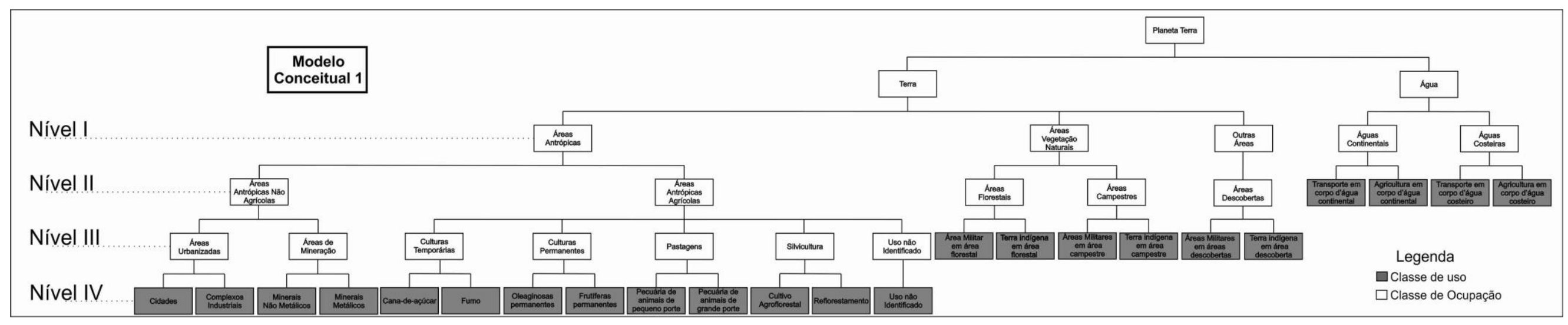

Figura 15: Modelo Conceitual 1

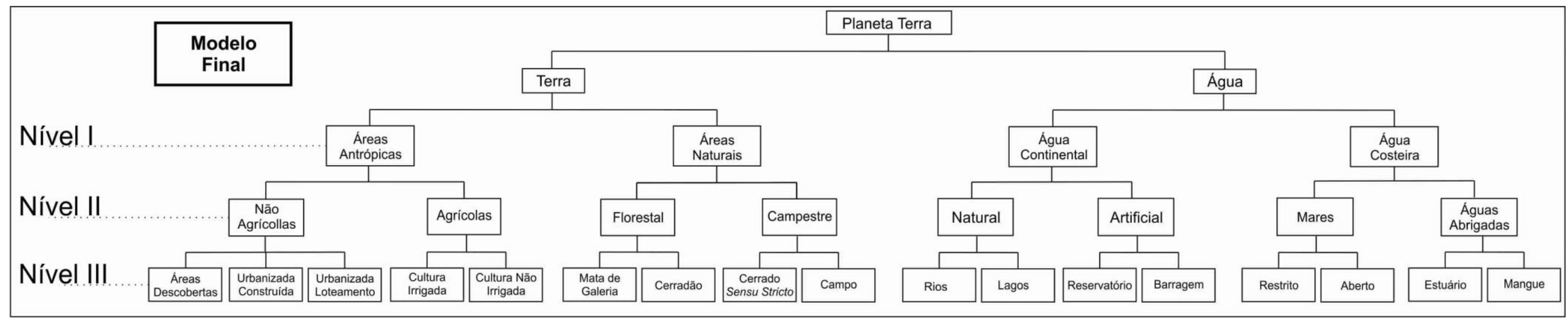

Figura 16: Modelo Final 


\subsection{Elaboração do Mapa de Uso do solo}

Após a aquisição da imagem foi realizada a composição colorida com as bandas 3(R), 2(G) e 1(B) do Sensor Multiespectral (pushbroom imager) eleitas devido a análise de quais bandas do sensor teriam melhores representações dos objetos em suas faixas espectrais. Vale lembrar, que a composição colorida da imagem utilizada, consta na figura 08 mapa de localização da área de estudo.

A construção do mapa de uso do solo foi baseado na técnica de vetorização em tela, utilizando o software ArcGIS 10.2, e a imagem RapidEye como referência (figura 17), vale ressaltar que a imagem utilizada estava georreferenciada no sistema de projeção UTM zona 22S, Datun WGS 1984.
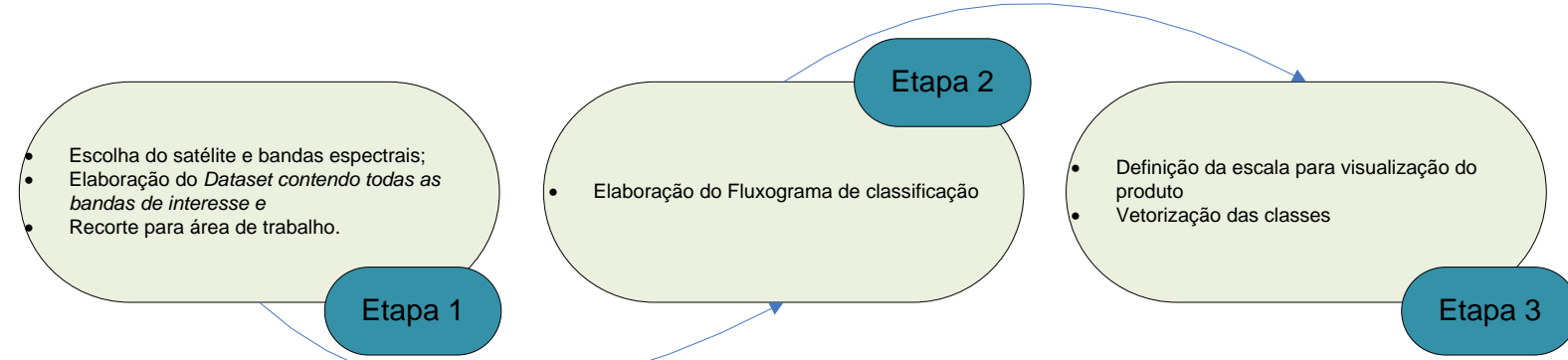

Figura 17: Etapas de elaboração do Mapa de Classificação

\section{Capítulo 3 - Resultado e Discussões}

Neste capítulo são apresentados e analisados os resultados obtidos na aplicação da metodologia proposta para a presente pesquisa. O quadro 02 apresenta todos os critérios, as alternativas e a média dos pesos definidos pelos pesquisadores utilizando o método AHP, para realização do pareamento das alternativas e critérios para elaboração dos mapas temáticos. 


\begin{tabular}{|c|c|c|c|c|c|}
\hline $\begin{array}{l}3 \text { Etapa de } \\
\text { Julgamento }\end{array}$ & 2 Etapa de Julgamento & 1 Etapa de Julgamento & $\begin{array}{l}3 \text { Etapa de } \\
\text { Julgamento }\end{array}$ & 2 Etapa de Julgamento & 1 Etapa de Julgamento \\
\hline \multirow{22}{*}{$\begin{array}{r}\text { Meio Físico } \\
(p=0,667)\end{array}$} & \multirow{7}{*}{$\begin{array}{l}\text { Uso do Solo } \\
(p=0,692)\end{array}$} & $\begin{array}{l}\text { Área Urbanizada sem infraestrutura } \\
\qquad(p=0,418)\end{array}$ & \multirow{19}{*}{$\begin{array}{l}\text { Meio social } \\
(p=0,333)\end{array}$} & \multirow{7}{*}{$\begin{array}{c}\text { Esgoto } \\
(\mathrm{p}=0,429)\end{array}$} & $\begin{array}{l}\text { Domicilios particulares permanentes sem banheiro } \\
\qquad(p=0,366)\end{array}$ \\
\hline & & $\begin{array}{l}\text { Área Urbanizada com infraestrutura } \\
\qquad(p=0,220)\end{array}$ & & & $\begin{array}{l}\text { Esgotamento sanitário via outro escoadouro } \\
\qquad(p=0,200)\end{array}$ \\
\hline & & $\begin{array}{l}\text { Área Descoberta } \\
(p=0,144)\end{array}$ & & & $\begin{array}{l}\text { Esgotamento sanitário via rio, lago ou mar } \\
\qquad(p=0,148)\end{array}$ \\
\hline & & $\begin{array}{l}\text { Cultura não irrigada } \\
\qquad(p=0,078)\end{array}$ & & & $\begin{array}{c}\text { Esgotamento sanitário via vala } \\
\qquad(\mathrm{p}=\mathbf{0 , 1 0 8 )}\end{array}$ \\
\hline & & $\begin{array}{l}\text { Cerrado Sensu Stricto } \\
\qquad(p=0,059)\end{array}$ & & & $\begin{array}{l}\text { Esgotamento sanitário via fossa rudimentar } \\
\qquad(\mathbf{p}=\mathbf{0 , 0 7 4 )}\end{array}$ \\
\hline & & $\begin{array}{l}\text { Cerradão } \\
(\mathbf{0}, 046)\end{array}$ & & & $\begin{array}{l}\text { Esgotamento sanitário via rede geral de esgoto ou } \\
\text { pluvial } \\
(p=0,052)\end{array}$ \\
\hline & & $\begin{array}{l}\text { Mata de Galeria } \\
(p=0,035)\end{array}$ & & & $\begin{array}{l}\text { Esgotamento sanitário via fossa séptica } \\
\qquad(p=0,052)\end{array}$ \\
\hline & \multirow{5}{*}{$\begin{array}{l}\text { Pluviosidade } \\
(\mathbf{p}=\mathbf{0 , 1 5 4 )}\end{array}$} & $\begin{array}{c}1550 \\
(p=0,323)\end{array}$ & & \multirow{8}{*}{$\begin{array}{c}\text { Lixo } \\
(p=0,429)\end{array}$} & $\begin{array}{l}\text { Outro destino do lixo } \\
(p=0,322)\end{array}$ \\
\hline & & $\begin{array}{c}1450 \\
(p=0,262)\end{array}$ & & & $\begin{array}{l}\text { Lixo jogado em rio, lago ou mar } \\
\qquad(\mathbf{p}=\mathbf{0 , 2 1 8})\end{array}$ \\
\hline & & $\begin{array}{c}1350 \\
(p=0,185)\end{array}$ & & & $\begin{array}{l}\text { Lixo jogado em terreno baldio ou logradouro } \\
\qquad(p=0,143)\end{array}$ \\
\hline & & $\begin{array}{c}1250 \\
(p=0,128)\end{array}$ & & & $\begin{array}{l}\text { Lixo enterrado na propriedade } \\
\qquad(p=0,085)\end{array}$ \\
\hline & & $\begin{array}{c}1150 \\
(p=0,102)\end{array}$ & & & $\begin{array}{l}\text { Lixo queimado na propriedade } \\
(p=0,085)\end{array}$ \\
\hline & \multirow{5}{*}{ Declividade $(p=0,080)$} & $\begin{array}{c}>20 \% \\
(p=0,419)\end{array}$ & & & $\begin{array}{l}\text { Lixo coletado em caçamba de serviço de limpeza } \\
\qquad(p=0,049)\end{array}$ \\
\hline & & $\begin{array}{l}10-20 \% \\
(\mathbf{p}=\mathbf{0}, \mathbf{2 6 3})\end{array}$ & & & $\begin{array}{l}\text { Lixo coletado por serviço de limpeza } \\
\qquad(p=0,049)\end{array}$ \\
\hline & & $\begin{array}{c}5-10 \% \\
(p=0,160)\end{array}$ & & & $\begin{array}{l}\text { Lixo coletado } \\
(p=0,049)\end{array}$ \\
\hline & & $\begin{array}{c}2-5 \% \\
(p=0,096)\end{array}$ & & \multirow{4}{*}{$\begin{array}{c}\text { Água } \\
(p=0,142)\end{array}$} & $\begin{array}{l}\text { Outra forma de abastecimento de água } \\
\qquad(p=0,424)\end{array}$ \\
\hline & & $\begin{array}{c}0-2 \% \\
(p=0,062)\end{array}$ & & & $\begin{array}{l}\text { Abastecimento de água de poço ou nascente na } \\
\text { propriedade } \\
(p=0,227)\end{array}$ \\
\hline & \multirow{5}{*}{$\begin{array}{l}\text { Pedologia } \\
(p=0,074)\end{array}$} & $\begin{array}{l}\text { Gleissolo Haplico } \\
\qquad(p=0,384)\end{array}$ & & & $\begin{array}{l}\text { Abastecimento de água da chuva armazenada em } \\
\text { cisterna } \\
(p=0,227)\end{array}$ \\
\hline & & $\begin{array}{l}\text { Cambissolo Háplico } \\
(p=0,178)\end{array}$ & & & $\begin{array}{c}\text { Abastecimento de água de rede geral } \\
(p=0,122)\end{array}$ \\
\hline & & $\begin{array}{l}\text { Latossolo Vermelho Amarelo } \\
\qquad(p=0,121)\end{array}$ & & & \\
\hline & & $\begin{array}{l}\text { Latossolo Vermelho } \\
(p=0,087)\end{array}$ & & & \\
\hline & & Plintossolo Petrico & & & \\
\hline
\end{tabular}

Quadro 2: Resultado do julgamento de pesos 
Na terceira etapa de julgamento dos pesos, ou seja, a fase em que se define o peso relativo que o meio físico e o saneamento exercem na análise proposta para a bacia, o meio físico desempenhou 66,7\% de influência no nível de qualidade ambiental em comparação com o saneamento, fatores como o uso do solo, pluviosidade, declividade e pedologia representam maior influência do que a gestão da água, esgoto e o lixo em bacias hidrográficas. Este resultado vem ao encontro dos estudos realizados por Ribeiro (2001), que identificou que o uso do solo tem grande contribuição na poluição e autodepuração nos rios Melchior e Descoberto, a partir de modelos matemáticos de simulação da qualidade da água, analisando as seguintes variáveis: Oxigênio dissolvido - OD, demanda bioquímica de oxigênio - DBO, demanda Química de Oxigênio - DQO, Nitrogênio Orgânico - Norg, Nitrogênio Amoniacal NH3, Nitrito - NO2, Nitrato - NO3, Fósforo Orgânico - Porg, Fósforo dissolvido - Pdiss, Coliformes totais - CT, Coliformes fecais - CF.

Dentro do uso do solo pode-se destacar a ocupação urbana com e sem infraestrutura, pois ela desempenha o maior nível de degradação ambiental, favorecendo o aumento do peso do meio físico encontrado no estudo. Já o saneamento, teve menor peso, exercendo 33,3\% de influência no nível de qualidade ambiental, comprovando a situação real de parte da área de estudo, onde, identifica-se a deficiência no tratamento de efluentes, abastecimento de água (existência de muitas cisternas, poços) e no gerenciamento de resíduos sólidos.

No meio físico, o uso do solo exerce $69,2 \%$ de influência, sendo assim, o que mais impacta a qualidade ambiental da bacia, sobrepondo-se à pluviosidade, declividade e pedologia. Os valores obtidos são confirmados quando se analisa a realidade da bacia, pois em diversos locais encontram-se a falta de infraestrutura, falta de direcionamento da água, falta de coleta de esgoto, falta de água potável, grandes áreas impermeáveis, entre outros, dados que são apresentados por autores como Callisto et al., (2002) que propôs um protocolo de avaliação rápida da diversidade de habitats como ferramenta em atividades de ensino e pesquisa, avaliando as características da água e sedimento, tipo de ocupação das margens, erosão e assoreamento, extensão de mata ciliar, cobertura vegetal, largura de rápidos e remansos e seu estado de conservação. Oliveira et al., (2014) através de levantamentos bibliográficos, observou que a falta de infraestrutura e a ausência de políticas efetivas podem ocasionar um aumento crescente de doenças de veiculação hídrica.

Aspectos como a pluviosidade, declividade e uso do solo podem influenciar na disponibilidade e a qualidade dos recursos naturais, provocar perda da biodiversidade, queda 
na fertilidade do solo, intensificação dos processos erosivos, poluição das águas, além de afetar a biodiversidade em toda a bacia. Mendoza et al., (2011) analisou o processo de mudança de cobertura da terra ao longo de um período de tempo e observou que o uso do solo, declividade e pluviosidade influencia na disponibilidade e qualidade dos recursos naturais, vindo ao encontro dos resultados obtidos na presente pesquisa.

Para a implementação do Mapa da Qualidade do Meio Físico, foram integrados os produtos referentes ao uso do solo, pluviosidade, Declividade e Pedologia, sendo representados pelas figuras $18,19,20$ e 21 .

A Figura 18, Mapa do Uso do Solo, apresenta os seguintes percentuais para cada classe de uso:

Tabela 4: Classes, peso e \% na Bacia do uso do solo

\begin{tabular}{ccc}
\hline Classe & Peso & \% na Bacia \\
\hline Área urbanizada sem infraestrutura & 0,418 & 6 \\
\hline Área urbanizada com infraestrutura & 0,220 & 25 \\
\hline Área descoberta & 0,200 & 3 \\
\hline Cultura não irrigada & 0,108 & 4 \\
\hline Cerrado Sensu Stricto & 0,079 & 49 \\
\hline Cerradão & 0,061 & 12 \\
\hline Mata de galeria & 0,044 & 12 \\
\hline
\end{tabular}




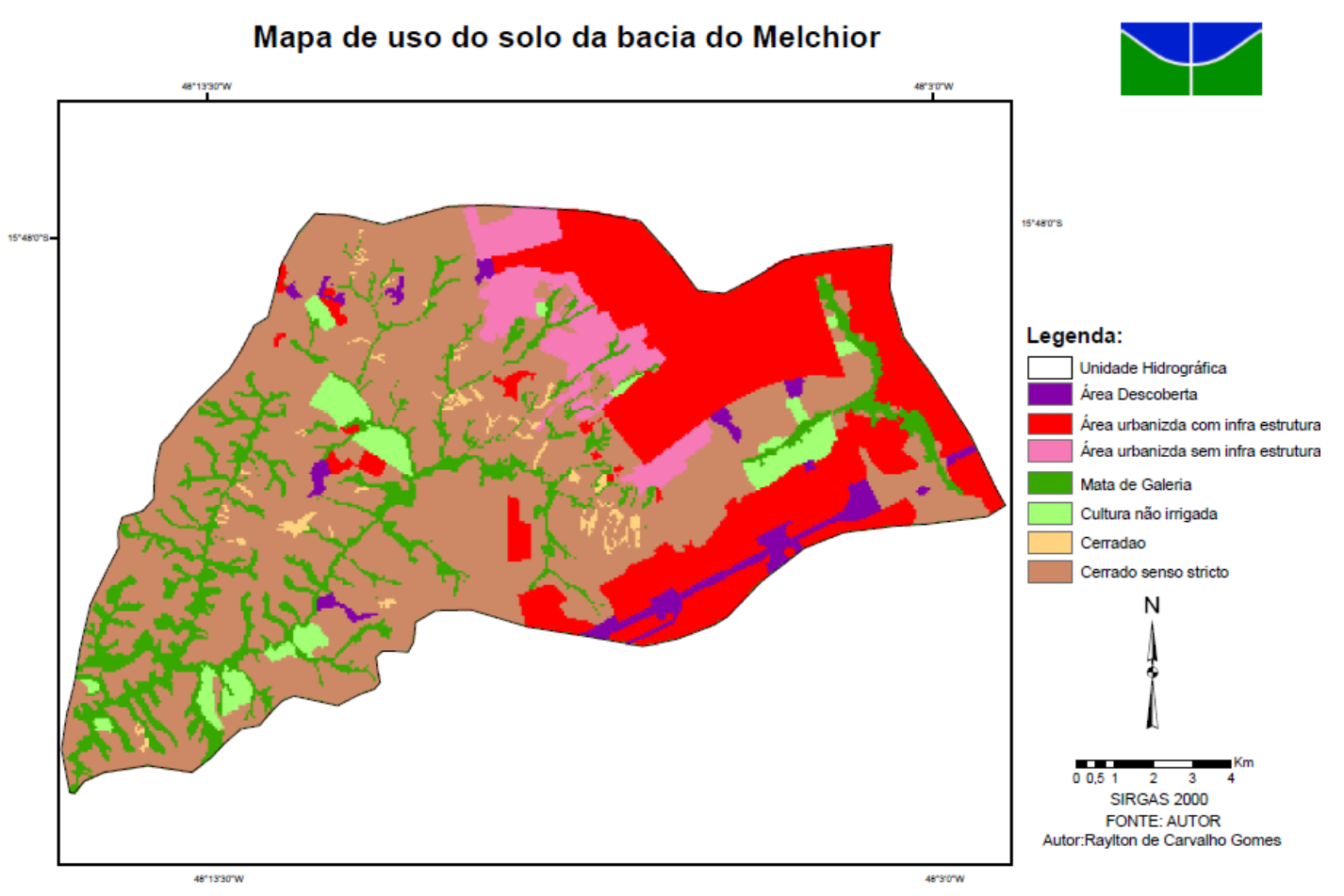

Figura 18: Mapa de uso do solo da bacia do Melchior

A análise do uso e ocupação do solo na Bacia do Melchior, demonstrou que as áreas urbanizadas com e sem infraestrutura e descobertas tem sua grande extensão a nordeste e a sudeste da bacia, cobrindo cerca de $34 \%$ da área total. São nessas áreas que estão localizadas as mais populosas cidades satélites do DF, como Samambaia, Taguatinga e Ceilândia, contabilizando em torno de 600.000 habitantes. Já os demais $66 \%$ da bacia, compreendendo as áreas sudoeste e noroeste, são ocupadas por Cerrado Senso Stricto, a Mata de galeria, Cerradão e as culturas não irrigadas.

Vale lembrar, que foram classificadas como áreas descobertas todas as áreas não incluídas no cerradão, cerrado senso stricto, cultura não irrigada, mata de galeria e áreas urbanizadas com e sem infraestrutura, e que compreendem e $3 \%$ da bacia.

Já o fator de pluviosidade, quanto maior a taxa de pluviosidade, maior foi o peso encontrado, isso indica que pluviosidades mais altas desempenham maior influência em uma bacia hidrográfica, devido ao poder de arrastar diversos materiais, além dos sedimentos para as áreas mais baixas do terreno, chegando aos corpos hídricos e intensificando os processos assoreamento, reduzindo os valores de nutrientes disponíveis no solo. 
Na elaboração do Mapa de pluviosidade (Figura 19) foram utilizados os dados dos produtos temáticos primários e julgados na primeira etapa de julgamento de pesos, obtendo os seguintes resultados:

Tabela 5: Classes, peso e \% na Bacia da pluviosidade

\begin{tabular}{ccc}
\hline Classe & Peso & \% na Bacia \\
\hline 1150 & 0,323 & 3 \\
\hline 1250 & 0,262 & 27 \\
\hline 1350 & 0,185 & 24 \\
\hline 1450 & 0,128 & 32 \\
\hline 1550 & 0,102 & 14 \\
\hline
\end{tabular}

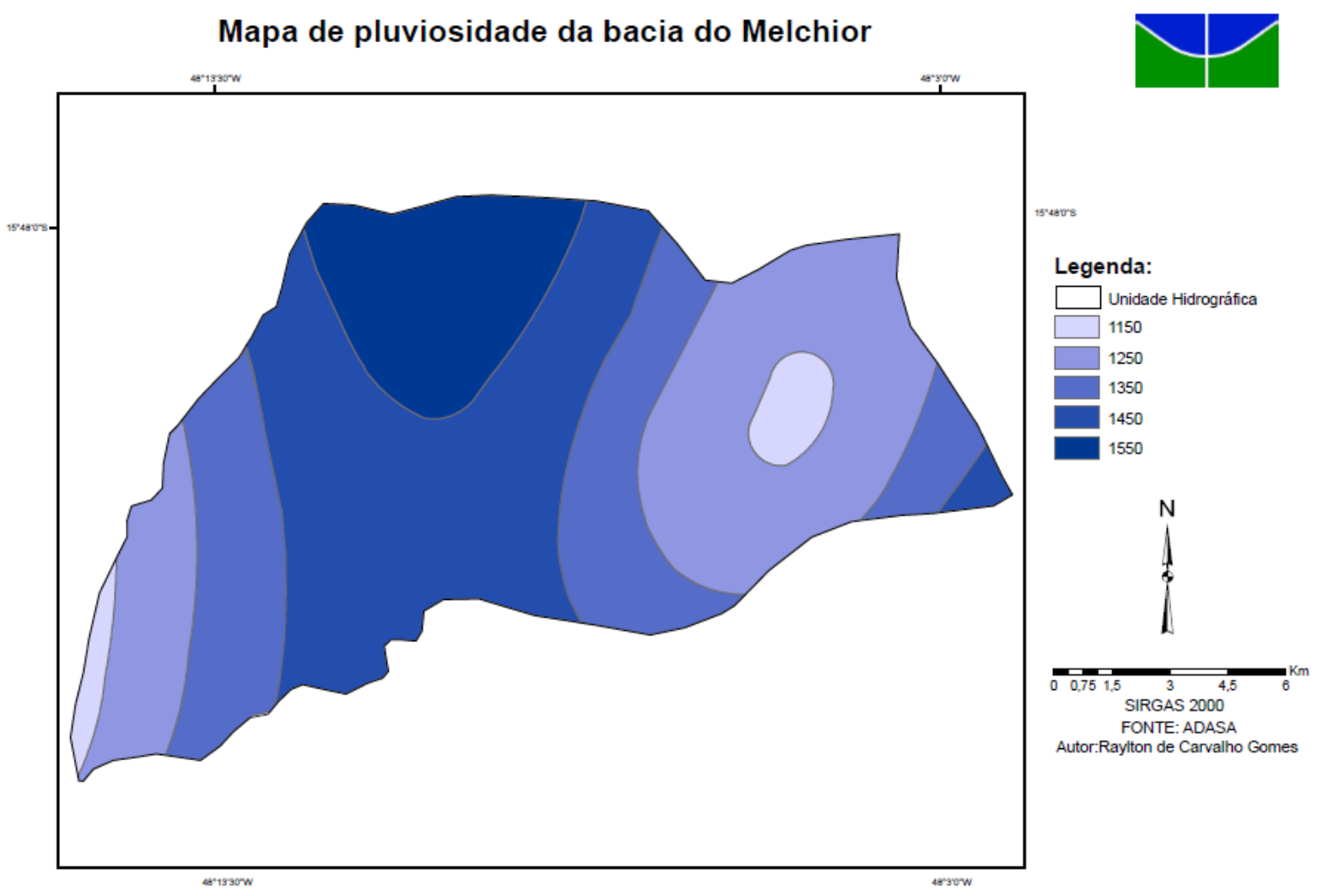

Figura 19: Mapa de pluviosidade da bacia do Melchior

$\mathrm{Na}$ figura 20 do mapa de declividade e na tabela 5 podem-se analisar os seguintes aspectos da bacia:

- a classe de maior impacto é a que representa a declividade $>20 \%$, mas, com uma representatividade baixa $-2 \%$, já a de menor impacto encontra-se na classe de $0-2 \%$, sendo a 
de maior peso e com uma maior representatividade na bacia com cerca de 44\%. A declividade de uma bacia hidrográfica tem relação com vários processos hidrológicos, tais como a infiltração, o escoamento superficial. Estudos desenvolvidos por Piroli e Campos, (2009) sugerem que as declividades superiores a $20 \%$ sejam ocupadas por atividades menos agressivas ao solo como, por exemplo, reflorestamento.

Tabela 6: Classes, peso e \% na Bacia de declividade

\begin{tabular}{ccc}
\hline Classe & Peso & \% na Bacia \\
\hline $0-2$ & 0,419 & 44 \\
\hline $2-5$ & 0,263 & 30 \\
\hline $5-10$ & 0,160 & 16 \\
\hline $10-20$ & 0,096 & 8 \\
\hline$>20$ & 0,062 & 2 \\
\hline
\end{tabular}

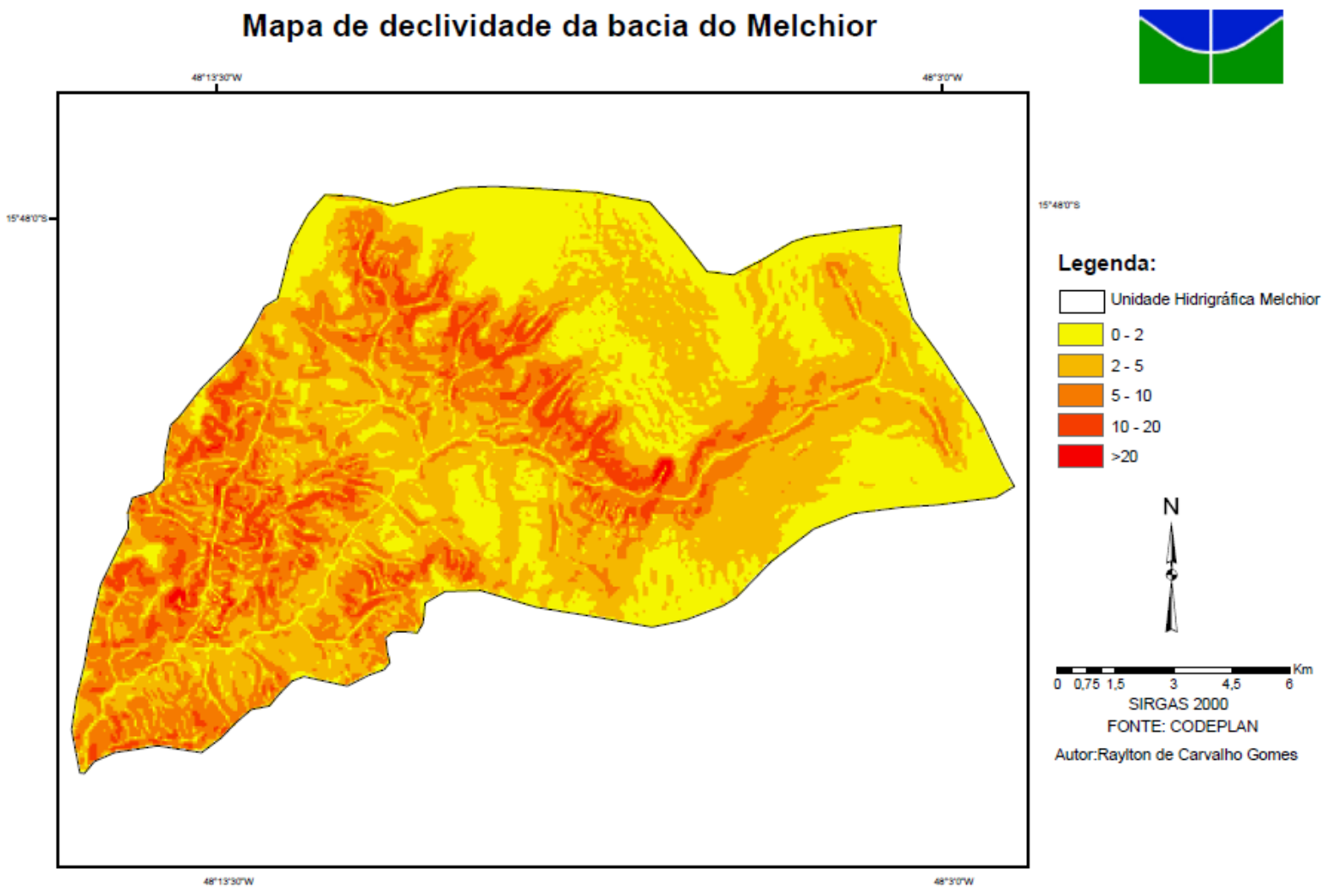

Figura 20: Mapa de declividade da bacia do Melchior 
Analisando-se o mapa de pedologia, figura 21, observa-se que $60 \%$ da bacia possui os solos do tipo latossólico, $38 \%$ o câmbico, mantendo a proporcionalidade existente para a área do Distrito Federal que é de 54,50\% e 30,98\%, respectivamente (EMBRAPA, 2004). A tabela 7 apresenta os tipos de solo e as suas respectivas porcentagens na bacia.

A influência dos pesos dos especialistas e consequentemente a classificação do AHP, posicionando a pedologia com o menor peso, reflete bem a realidade da bacia, em razão dos seus índices de declividade, pois como pode-se constatar, $74 \%$ da bacia encontra-se na faixa de declividade de 0 a 5\%, caracterizando relevos plano e suave-ondulados. Os resultados estão em consonância com os estudos de Lopes e Pejon, (2001), Ribeiro e Salomão, (2001) e Silva et al., (2007) que descrevem a relação entre a declividade e a pedologia do terreno, definindo que em áreas mais planas encontram-se os solos mais intemperizados e mais velhos, portanto mais desenvolvidos e, em locais com menor declividade ocorrem os solos mais jovens.

Tabela 7: Classes, peso e \% na Bacia de pedologia

\begin{tabular}{ccc}
\hline Tipo do solo & Peso & \% na Bacia \\
\hline Plintossolo Petrico & 0,384 & 0,8 \\
\hline Latossolo vermelho-amarelo & 0,178 & 4 \\
\hline Latossolo vermelho & 0,121 & 56 \\
\hline Gleissolo Háplico & 0,087 & 1,2 \\
\hline Cambissolo Háplico & 0,230 & 38 \\
\hline
\end{tabular}




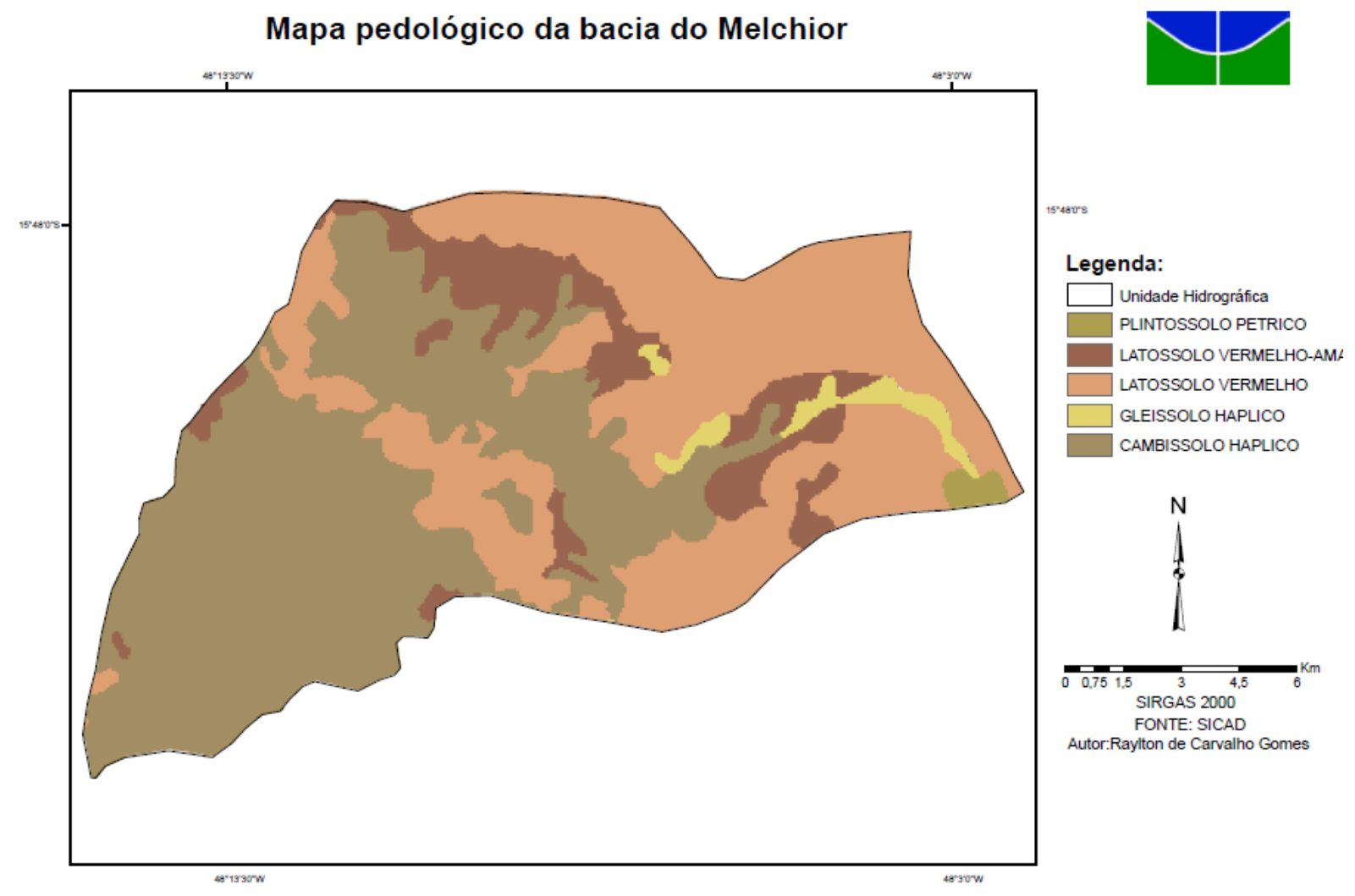

Figura 21: Mapa pedológico da bacia do Melchior.

O mapa de integração do meio físico, figura 22, foi obtido a partir da integração dos dados do meio físico. 


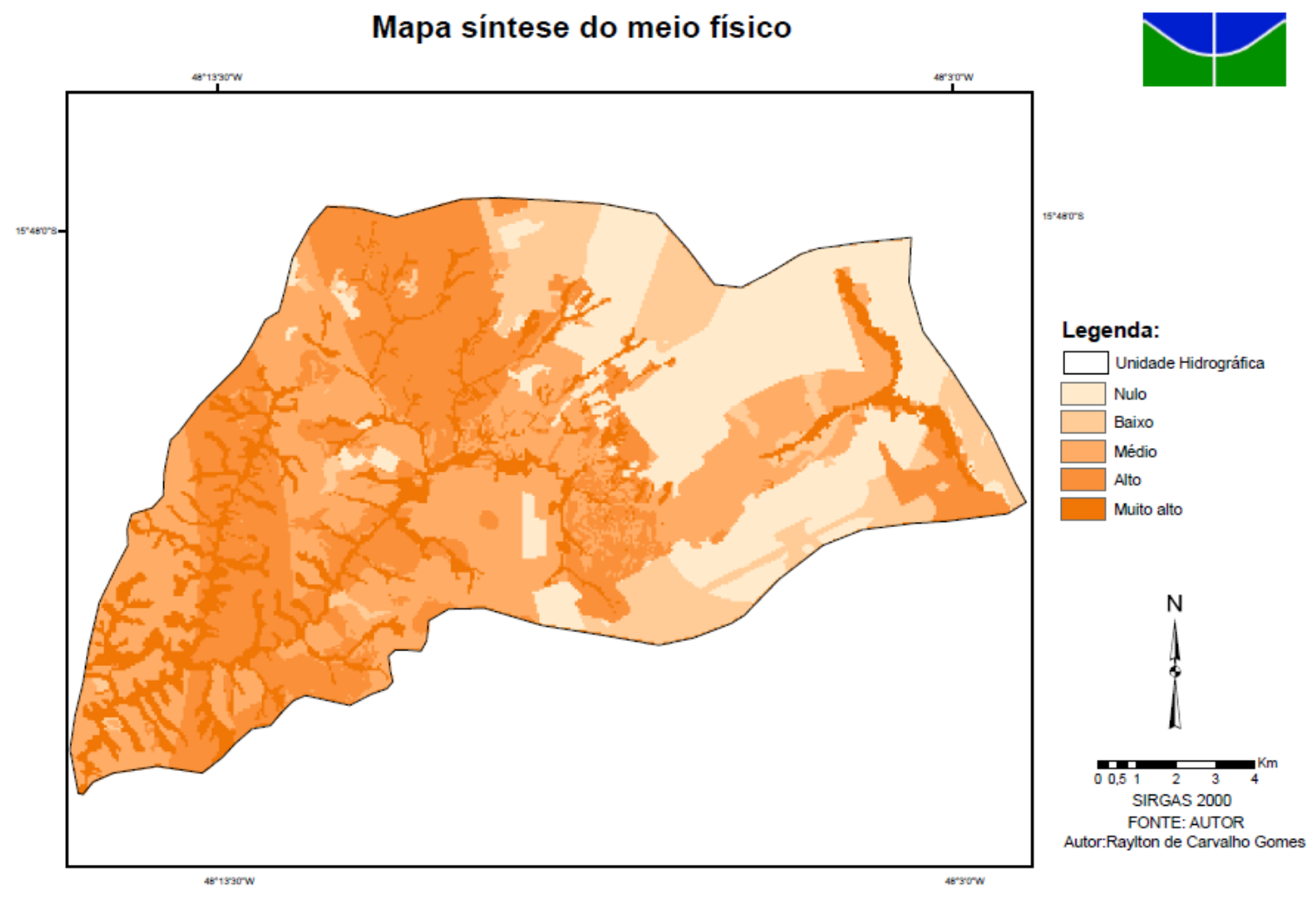

Figura 22: Mapa síntese do meio físico

Da figura 22 pode-se analisar os seguintes aspectos:

$12 \%$ da área foi classificada com o nível de qualidade muito alta, 23\% alta, 33\% média, $16 \%$ baixa e $16 \%$ nula.

Observa-se que as áreas com os maiores níveis (alta e muito alta) de qualidade, encontram-se margeando ou próximo às redes de drenagem, portanto, pode-se deduzir que a mesma seja de Mata de Galeria que recebeu o menor peso por parte dos especialistas, significando que possui a maior influência na qualidade ambiental. Este fato pode ser comprovado na Figura 23. 


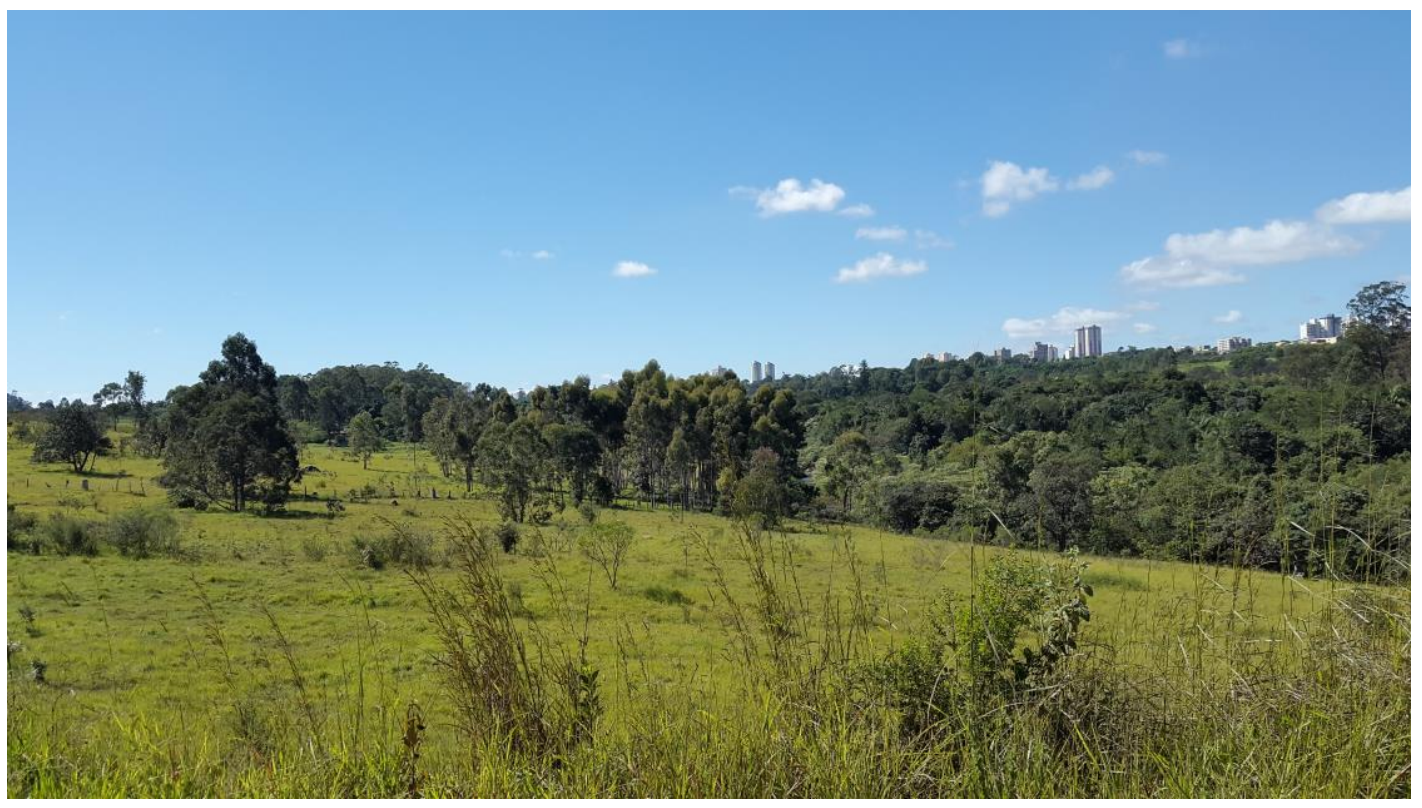

Figura 23: Áreas com mata de galeria

Contrariamente, deve-se ter maior preocupação com as áreas de qualidade classificadas como nulo e baixo níveis de qualidade, que estão localizadas em sua grande maioria nas áreas urbanizadas.

Verificou-se que as áreas urbanizadas sem a correta infraestrutura, representando $6 \%$ de participação na bacia, ocupa uma área de $12,5 \mathrm{~km}^{2}$. Os elementos impactantes desta área são apresentados nas figuras 24 e 25 . Vale destacar que essas áreas tem pequena representatividade na bacia, localizadas na parte nordeste das áreas urbanizadas, onde se encontra as ocupações irregulares do solo.

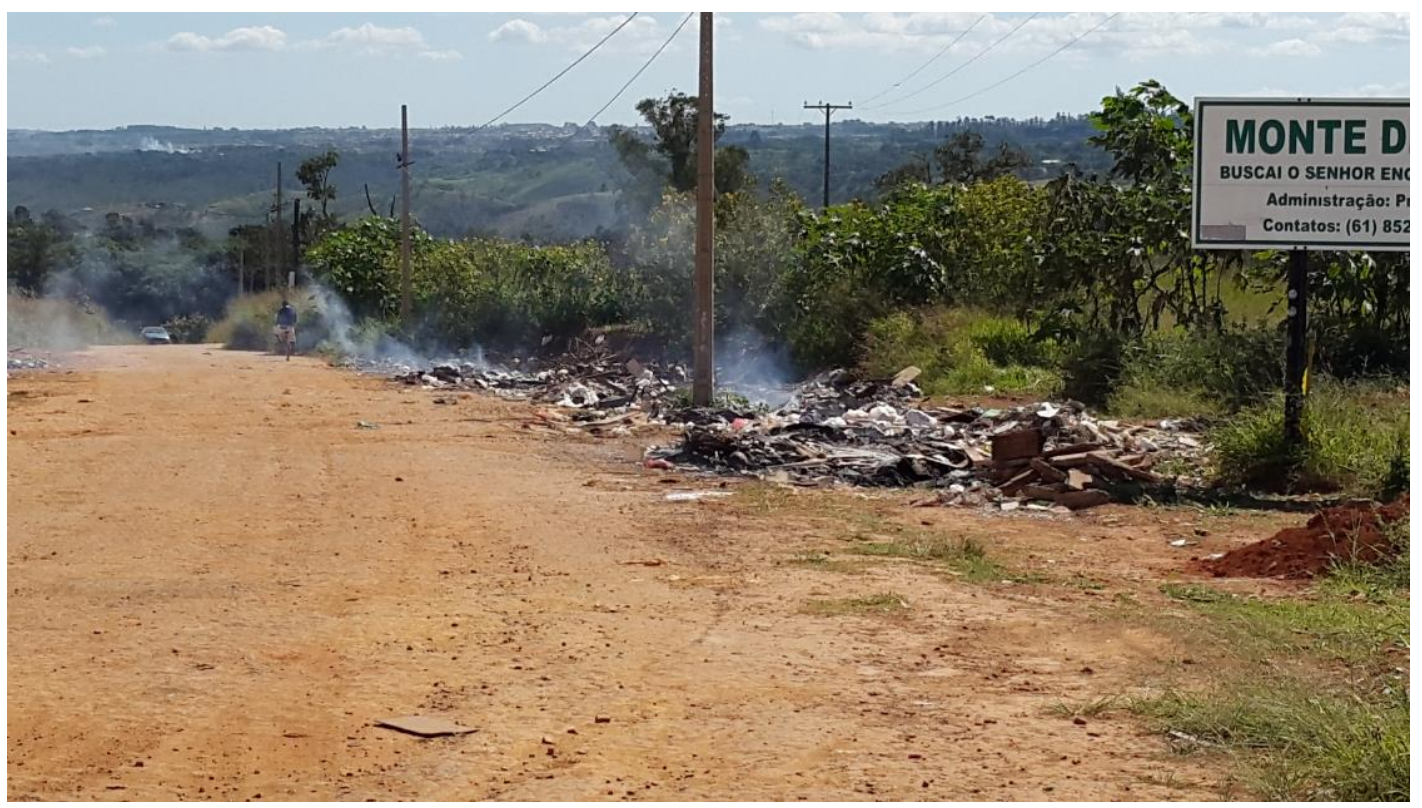

Figura 24: Falta de infraestrutura 


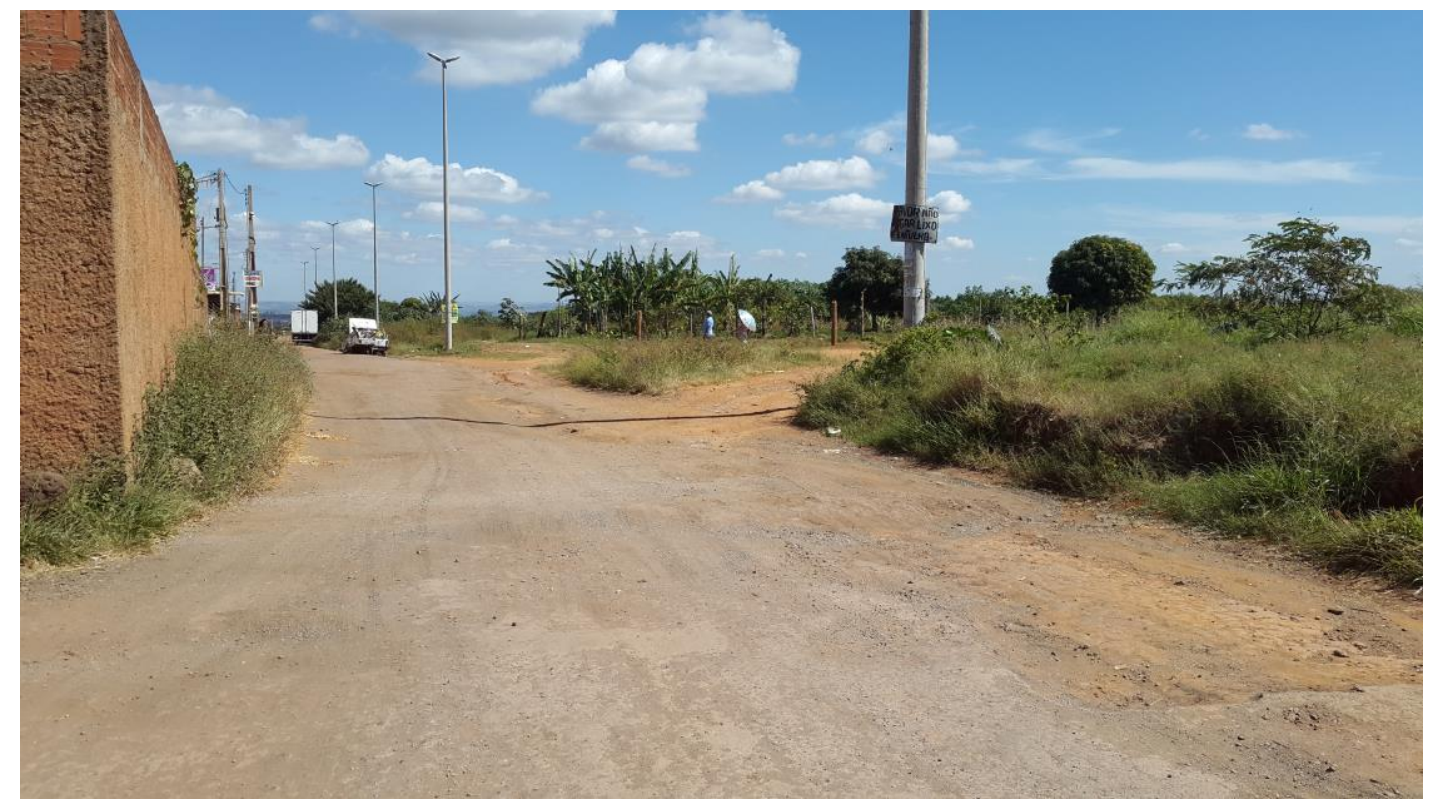

Figura 25: Falta de infraestrutura

As áreas urbanizadas com infraestrutura consolidada representam 25\% da área da bacia, totalizando 51,9 km², essas áreas possuem orientação das águas pluviais, asfalto, rede de água, de luz e de esgotamento sanitário como apresentado nas figuras 26, 27 e 28. Esta área incorpora parte das cidades satélites de Ceilândia, Samambaia e Taguatinga. Possuindo maior representatividade no mapa de uso do solo, e menor peso, assumindo menor influência que áreas urbanizadas sem infraestrutura.

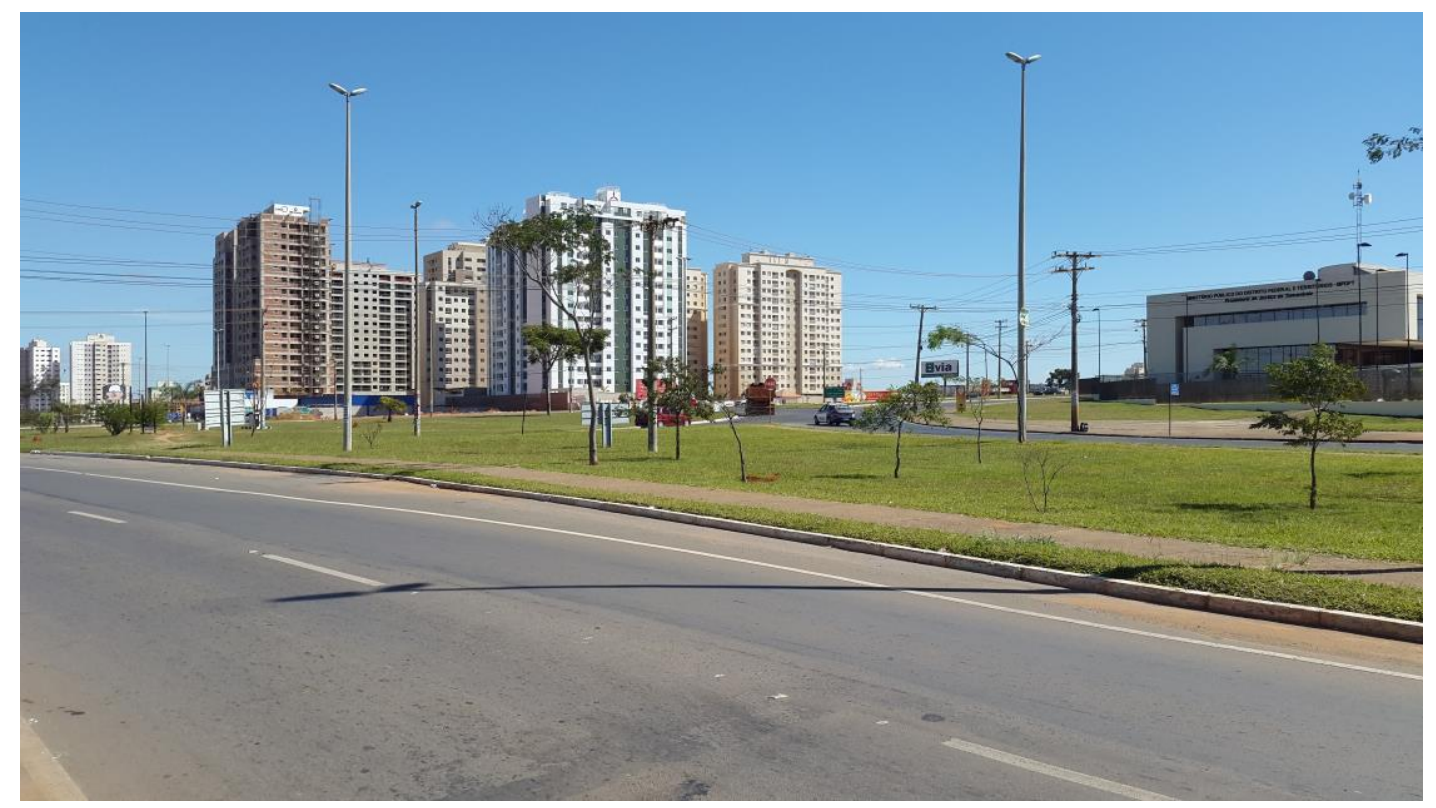

Figura 26: Áreas com infraestrutura 


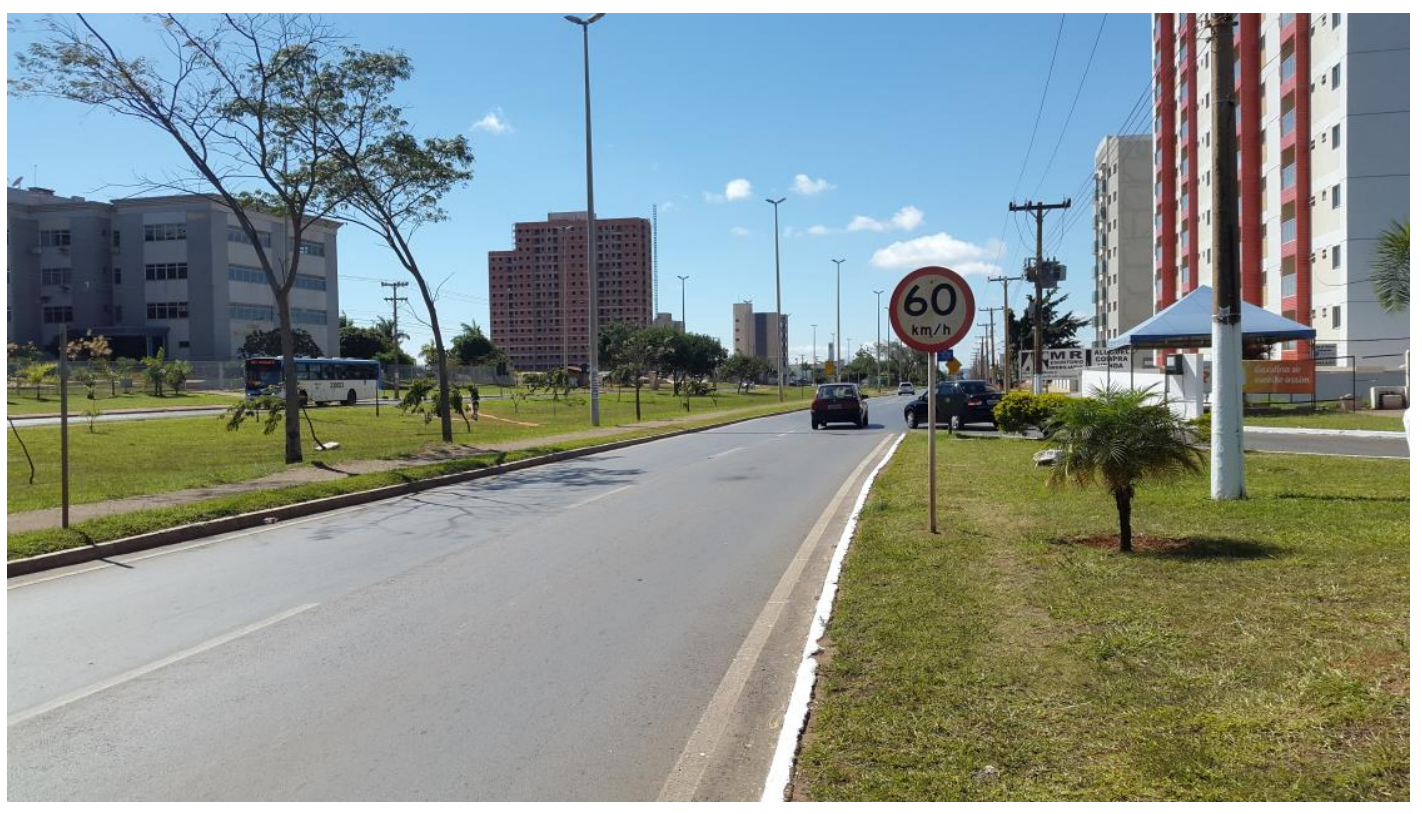

Figura 27; Áreas com infraestrutura

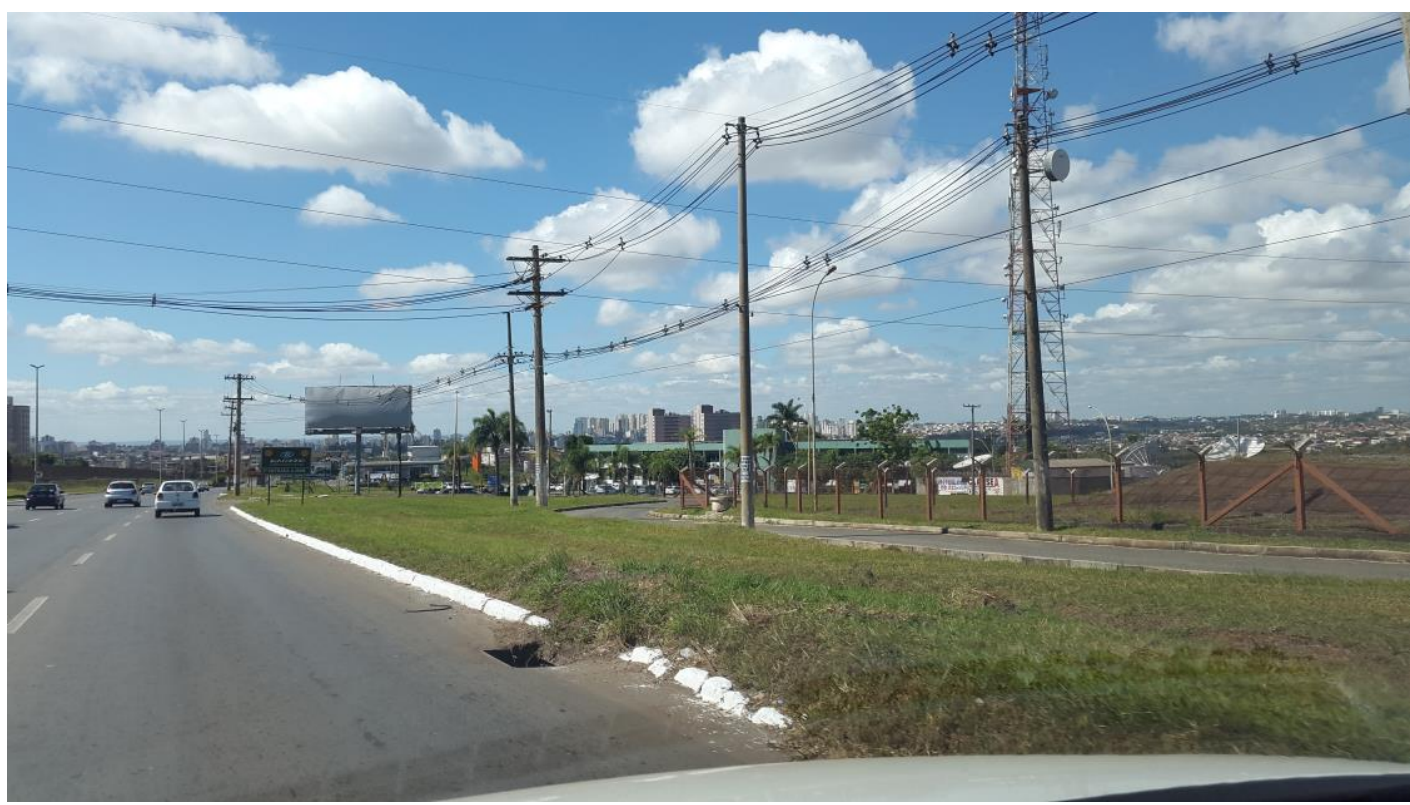

Figura 28: Áreas urbanizadas

A definição dos pesos pelos especialistas e a avaliação do AHP, demonstraram um grau de dependência entre as variáveis da seguinte forma: a pedologia sofre influência da declividade e da pluviosidade, à medida que ocorre um maior índice pluviométrico. Este resultado vem ao encontro dos estudos apresentados por Lopes e Pejon, (2001), que demonstraram, por meio da interação destes fatores, a influência dos mesmos na geração de processos erosivos, e consequentemente, influenciando os níveis de qualidade ambiental. Lopes e Pejon, (2001), utilizou uma série de atributos do meio físico, como geologia, 
pedologia, materiais inconsolidados, declividade e CEMPAS (Carta de Extensão do Menor Percurso da Água Superficial), representados na escala 1:50.000, na elaboração das cartas de Susceptibilidade à Erosão do Rio Passa Cinco, por meio do Sistema de Informação Geográfica (SIG-IDRISI).

$\mathrm{Na}$ análise do saneamento, os dois aspectos que obtiveram os maiores pesos foram os resíduos sólidos, a coleta e destinação de esgoto, representando respectivamente $85,8 \%$ e a classe que apresentou a menor influência foi à água com $14,2 \%$.

Os valores encontrados refletem bem a realidade do que ocorre em $6 \%$ da bacia do Rio Melchior, principalmente, em razão da forma como é feito o descarte irregular de resíduos sólidos e o processo de coleta e destinação do esgoto (figura 29 e 30), demonstrando a deficiência de saneamento na área de estudo. Os dados apontam para a efetividade dos pesos definidos pelos especialistas e para estruturação do modelo AHP, no entanto, não foi possível demonstrar da mesma forma a qualidade ambiental da área urbana com infraestrutura, pois nela existe todo um sistema de fornecimento de água potável, coleta de lixo e sistema de coleta de esgoto.

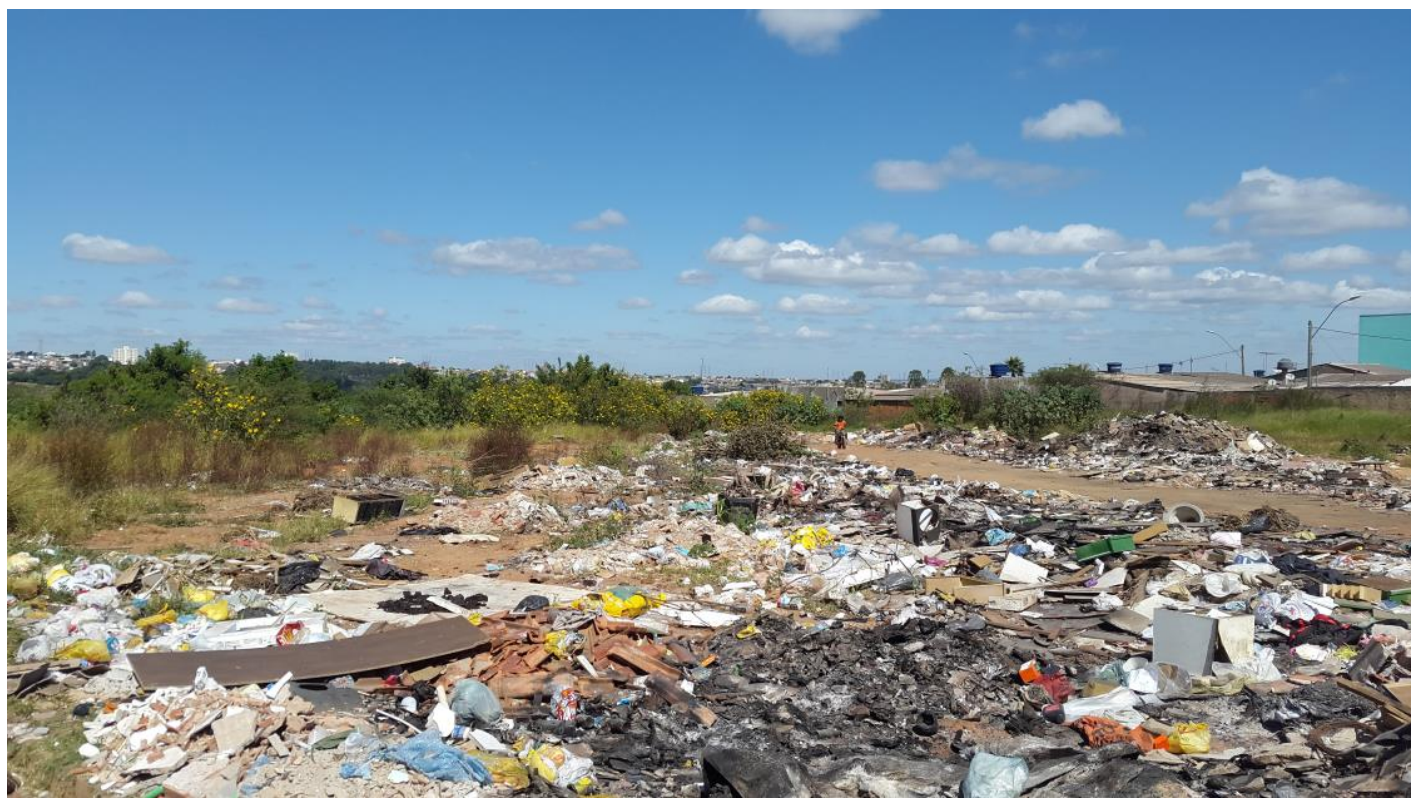

Figura 29: Descarte inadequado de lixo 


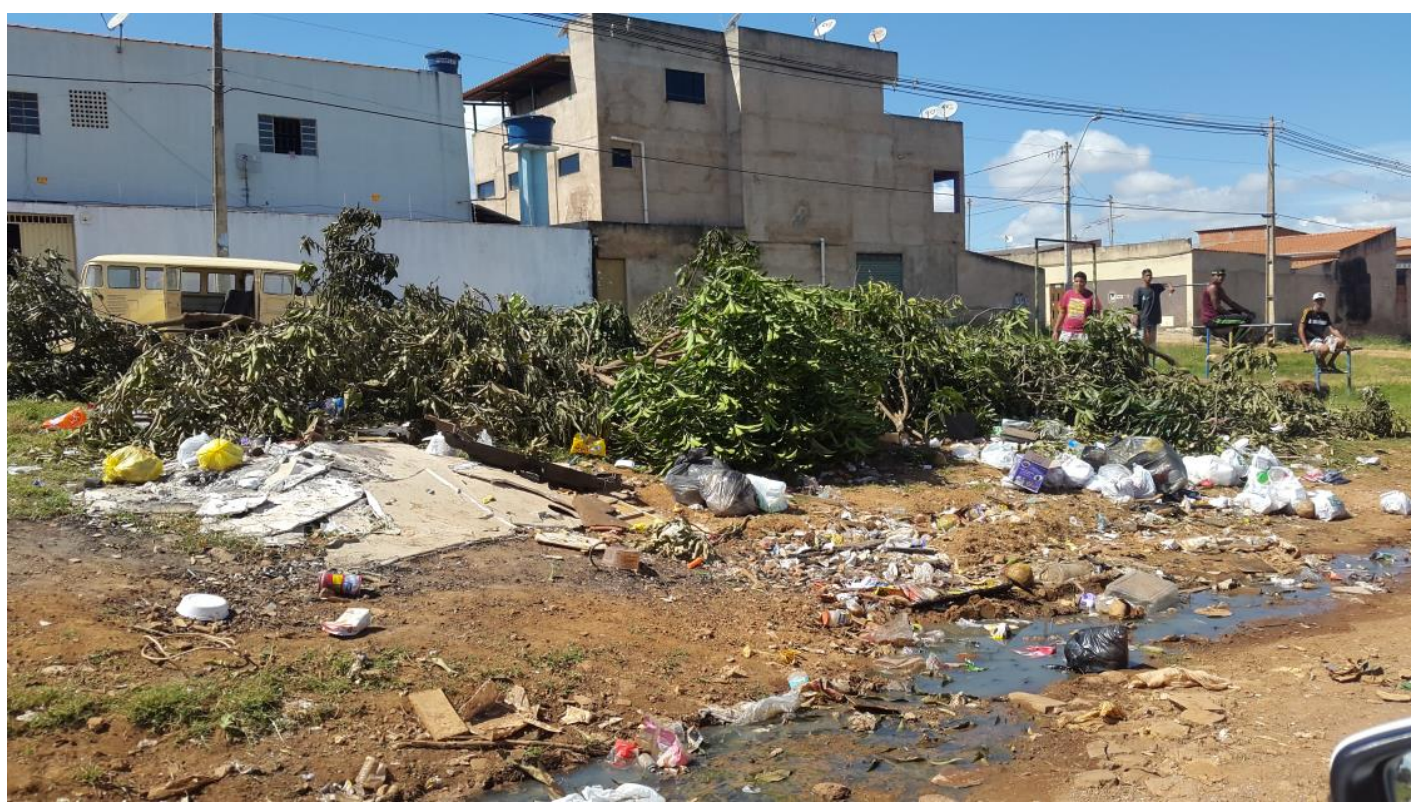

Figura 30: Descarte inadequado do lixo e esgoto

O menor peso na classificação do AHP foi para o fator água. O posicionamento na classificação também reflete a realidade dos $6 \%$ localizado na porção nordeste/sudeste da bacia, que não possui na sua totalidade sistema de distribuição de água, sendo necessário o uso de cisternas e poços. Já, as áreas urbanizadas com infraestrutura representando $25 \%$ da bacia possui atendimento pela CAESB - Companhia de Saneamento Ambiental do DF. Observa-se que os outros $69 \%$ da bacia, totalizando $143,4 \mathrm{~km}^{2}$, representados pelas áreas rurais utilizam poços para o seu abastecimento de água e o esgotamento sanitário é feito em fossas sépticas.

De acordo com estudos desenvolvidos por Zamariola et al., (2010) e Abrelpe, (2013) elementos como disposição inadequada de resíduos sólidos e esgotos lançados a céu aberto ou em cursos d'água exercem maior impacto na qualidade ambiental que o processo de captação de água por cisternas e poços.

Objetivando gerar o mapa de qualidade do saneamento, foram integrados os temas relacionados na etapa 1 do julgamento. Todos os temas foram normalizados para o mesmo número de classes. A figura 54 apresenta a integração dos dados do saneamento, e as figuras dos temas que compuseram o produto, são apresentadas nas figuras 39, 48 e 53.

Para composição do mapa síntese de esgoto (figura 38), foram utilizados 7 (sete) produtos (figuras 31 a 37), obtidos da base do censo do IBGE (2010). 
Domicílios particulares permanentes com banheiro de uso exclusivo dos moradores ou sanitário e esgotamento sanitário via rede geral de esgoto ou pluvial

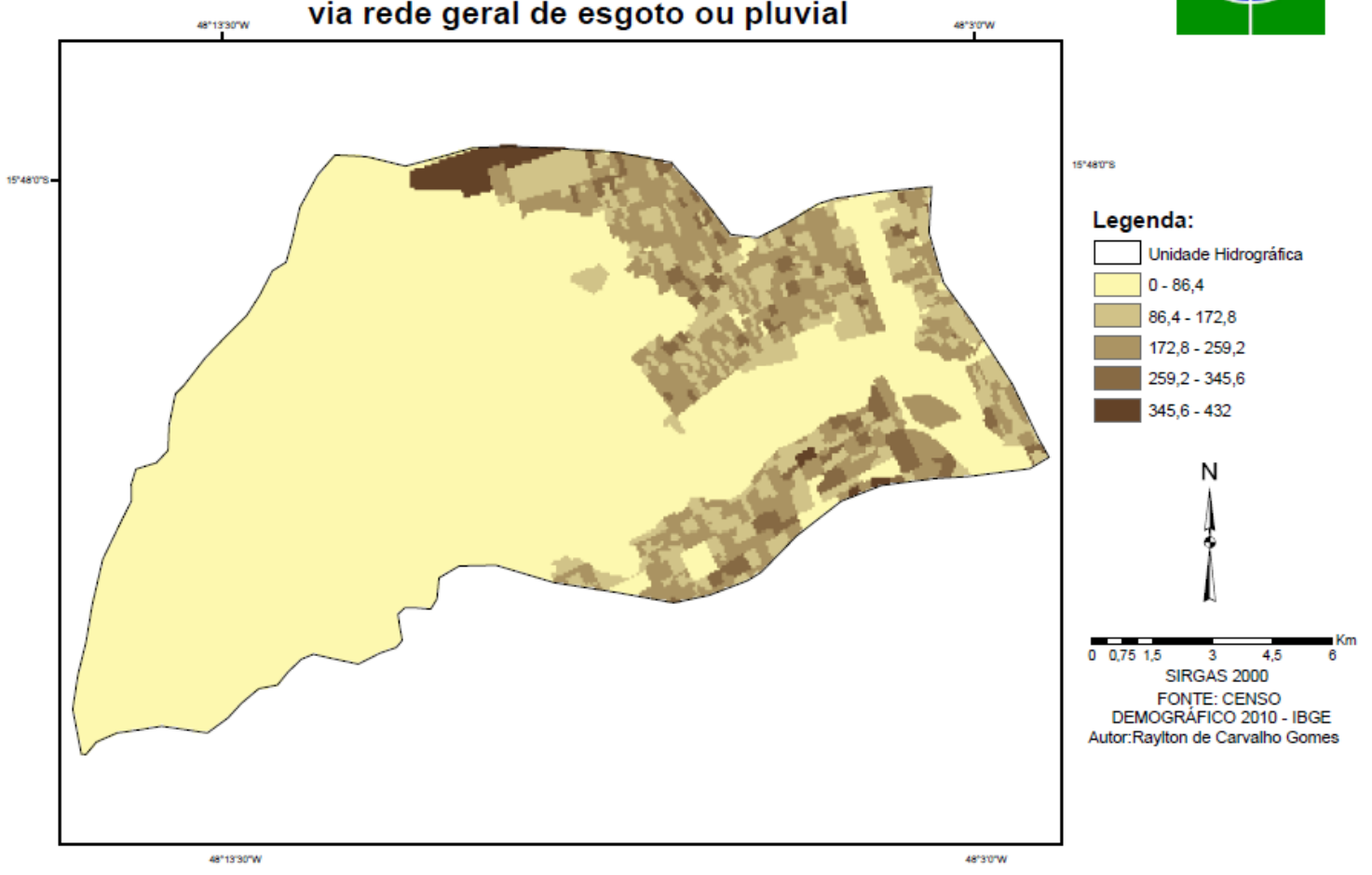

Figura 31: Domicílios particulares permanentes com banheiro de uso exclusivo dos moradores ou sanitário e esgotamento sanitário via rede geral de esgoto ou pluvial

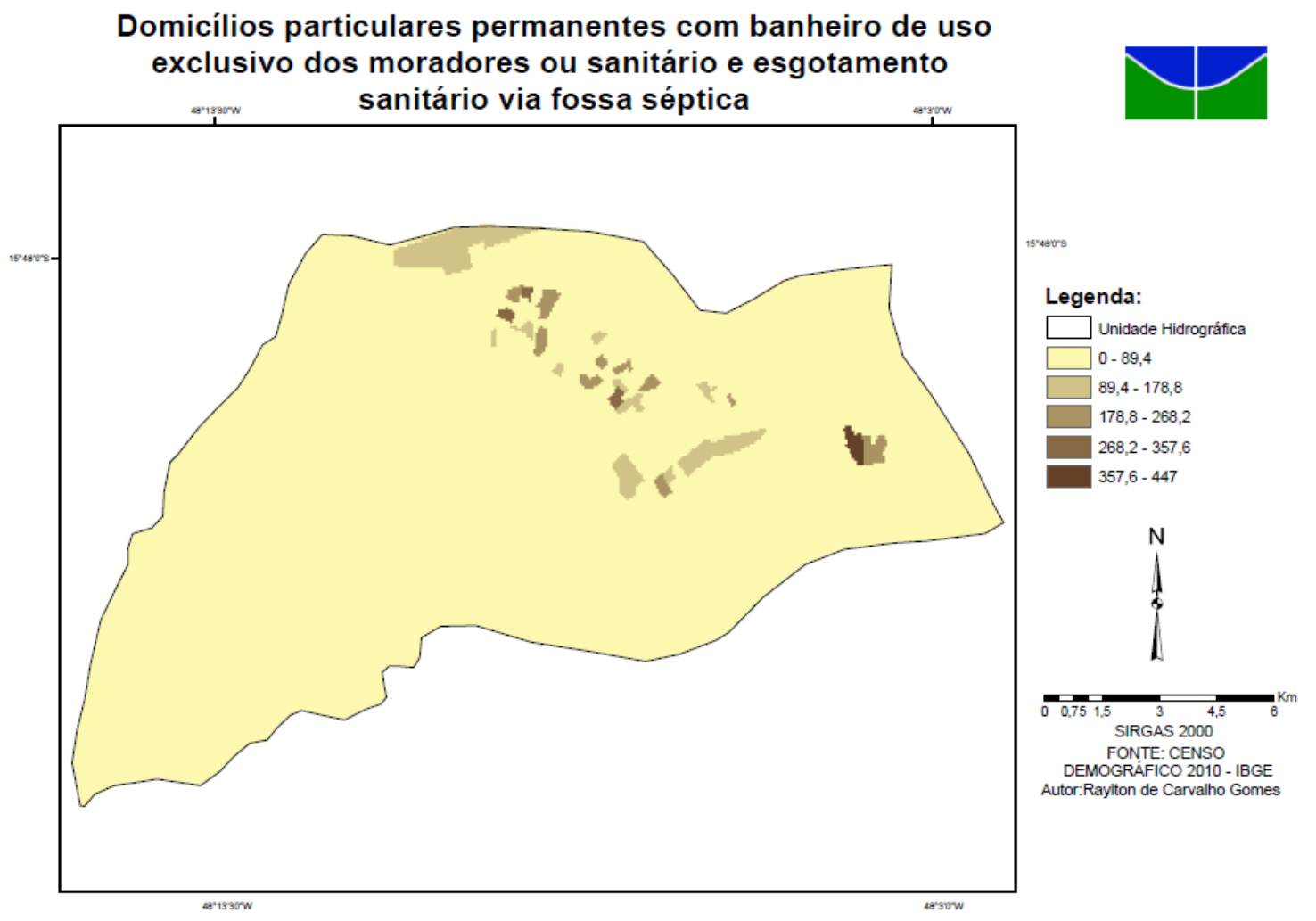

Figura 32: Domicílios particulares permanentes com banheiro de uso exclusivo dos moradores ou sanitário e esgotamento sanitário via fossa séptica 


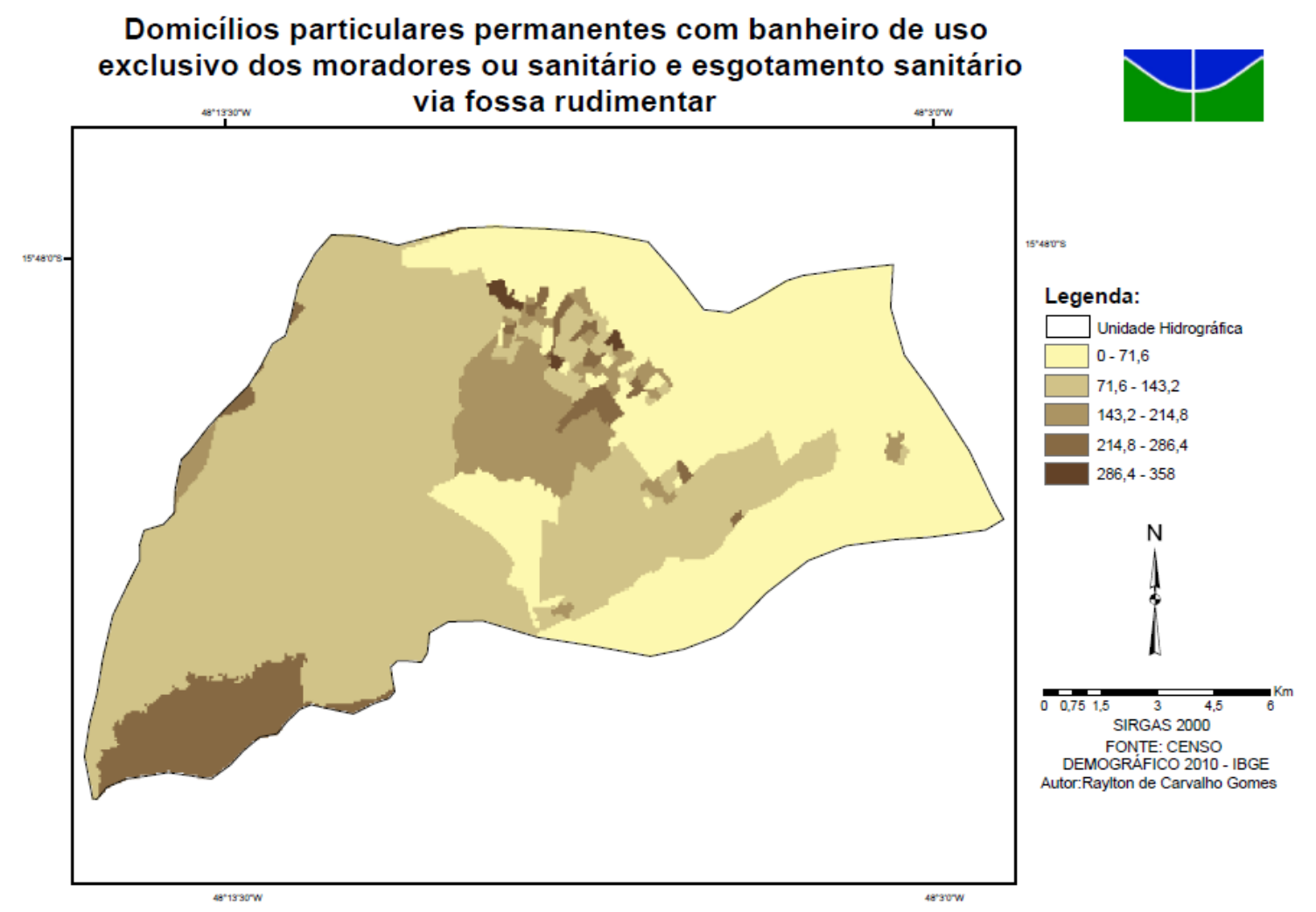

Figura 33: Domicílios particulares permanentes com banheiro de uso exclusivo dos moradores ou sanitários e esgotamento sanitário via fossa rudimentar

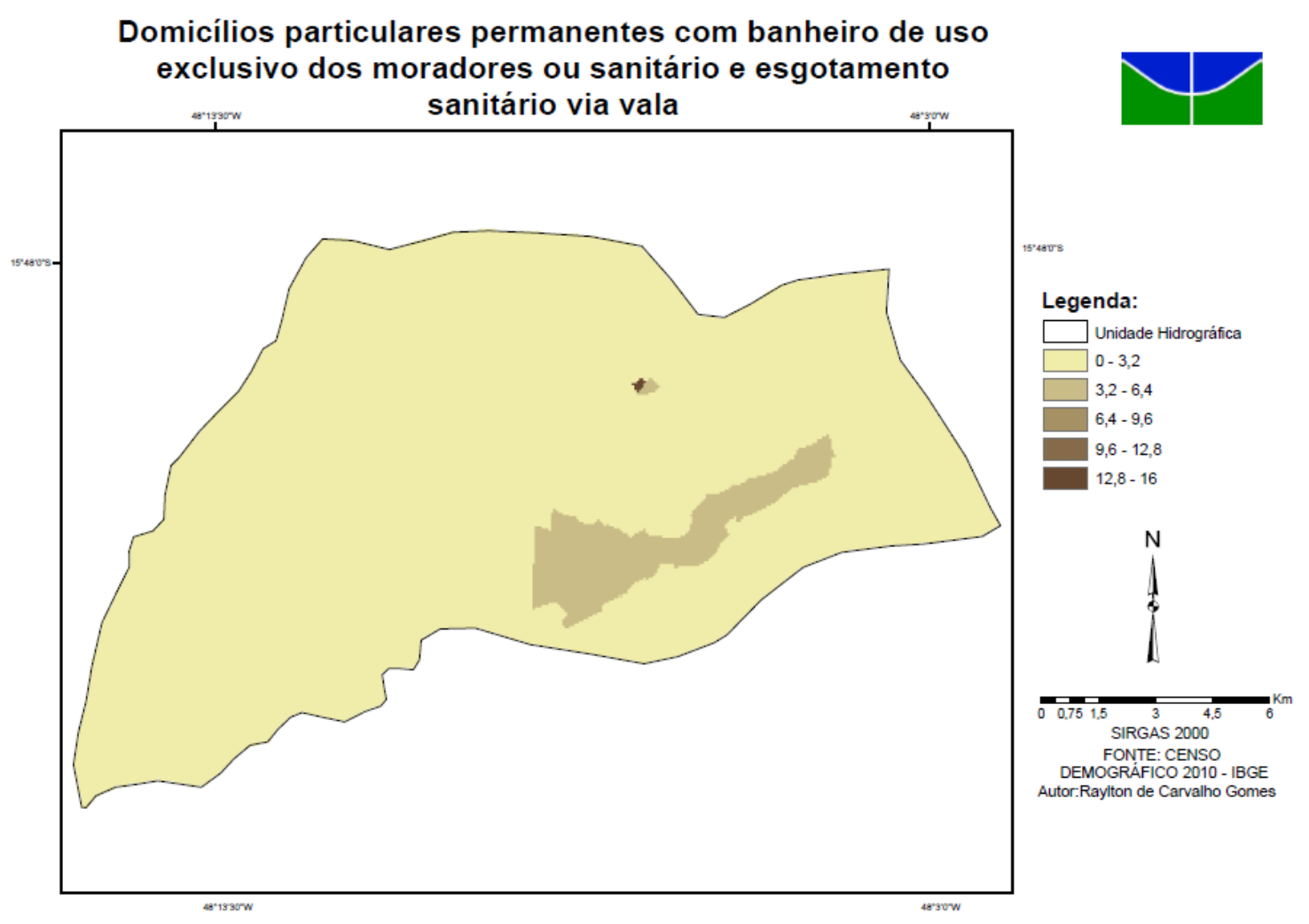

Figura 34: Domicílios particulares permanentes com banheiro de uso exclusivo dos moradores ou sanitários e esgotamento sanitário via vala 
Chama atenção que as regiões de Taguatinga, Ceilândia e Samambaia são áreas urbanizadas com infraestrutura consolidada, que possuem orientação das águas pluviais, asfalto, rede de água, de luz e de esgotamento sanitário conforme apresentado anteriormente nas figuras 26, 27 e 28, e que não possuem esgotamento sanitário via rio, lago ou mar, ou seja, a figura 35, pois seus dados não expressam a verdadeira realidade da bacia com relação ao esgotamento sanitário via rio, lago ou mar apresentado no Censo do IBGE.

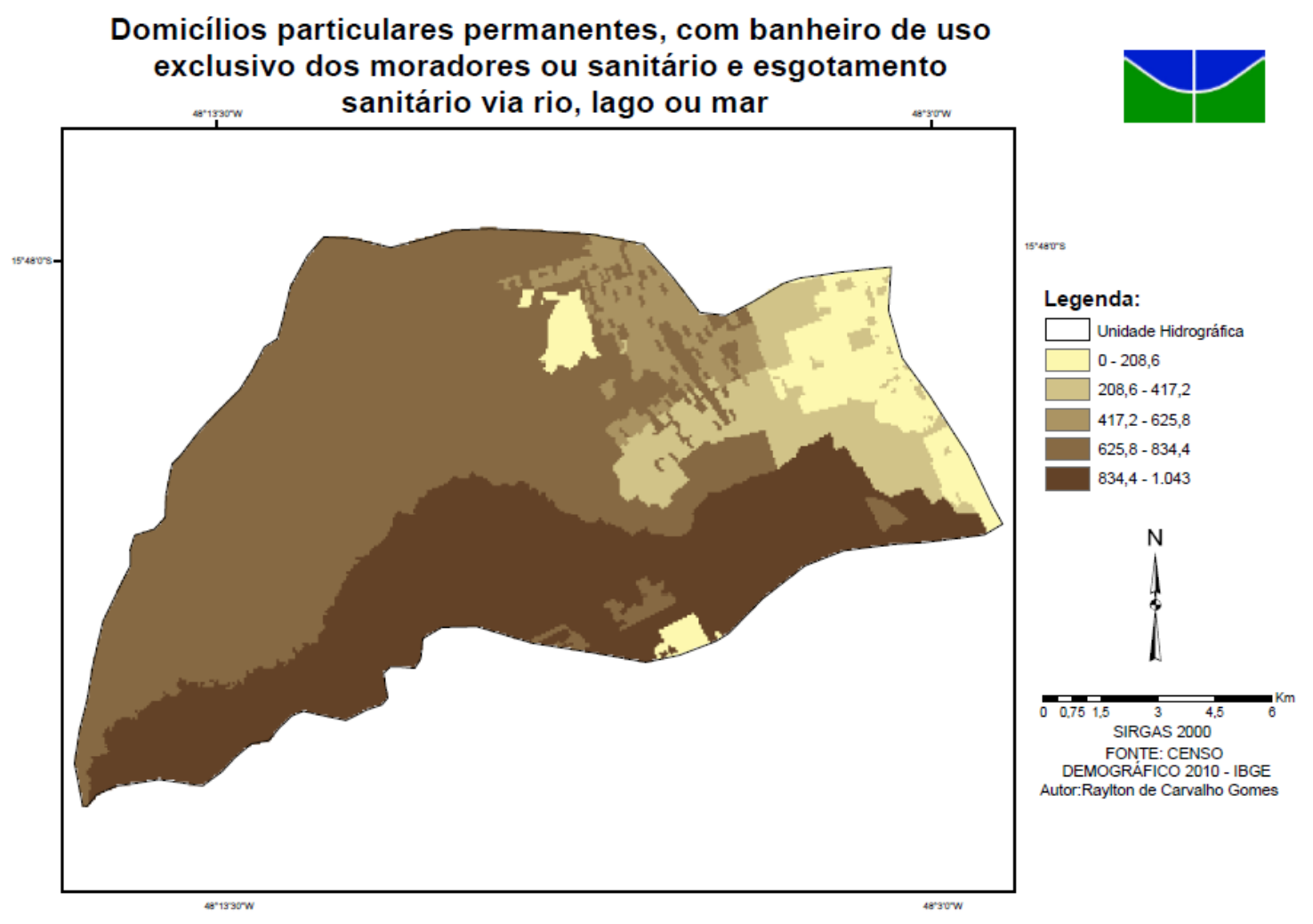

Figura 35: Domicílios particulares permanentes, com banheiro de uso exclusivo dos moradores ou sanitário e esgotamento sanitário via rio, lago ou mar 


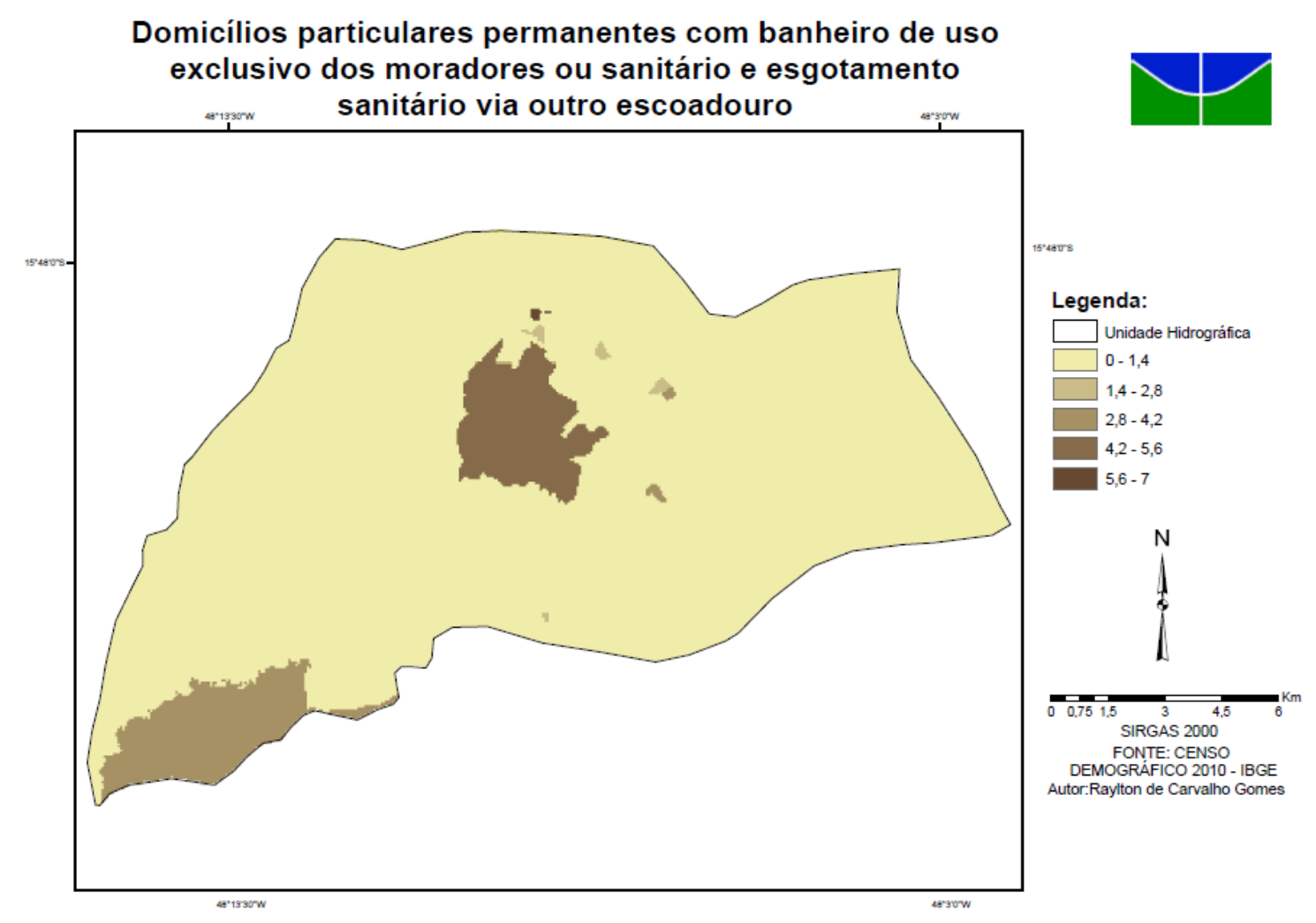

Figura 36: Domicílios particulares permanentes com banheiro de uso exclusivo dos moradores ou sanitário e esgotamento sanitário via outro escoadouro

Domicílios particulares permanentes sem banheiro de uso exclusivo dos moradores e nem sanitário

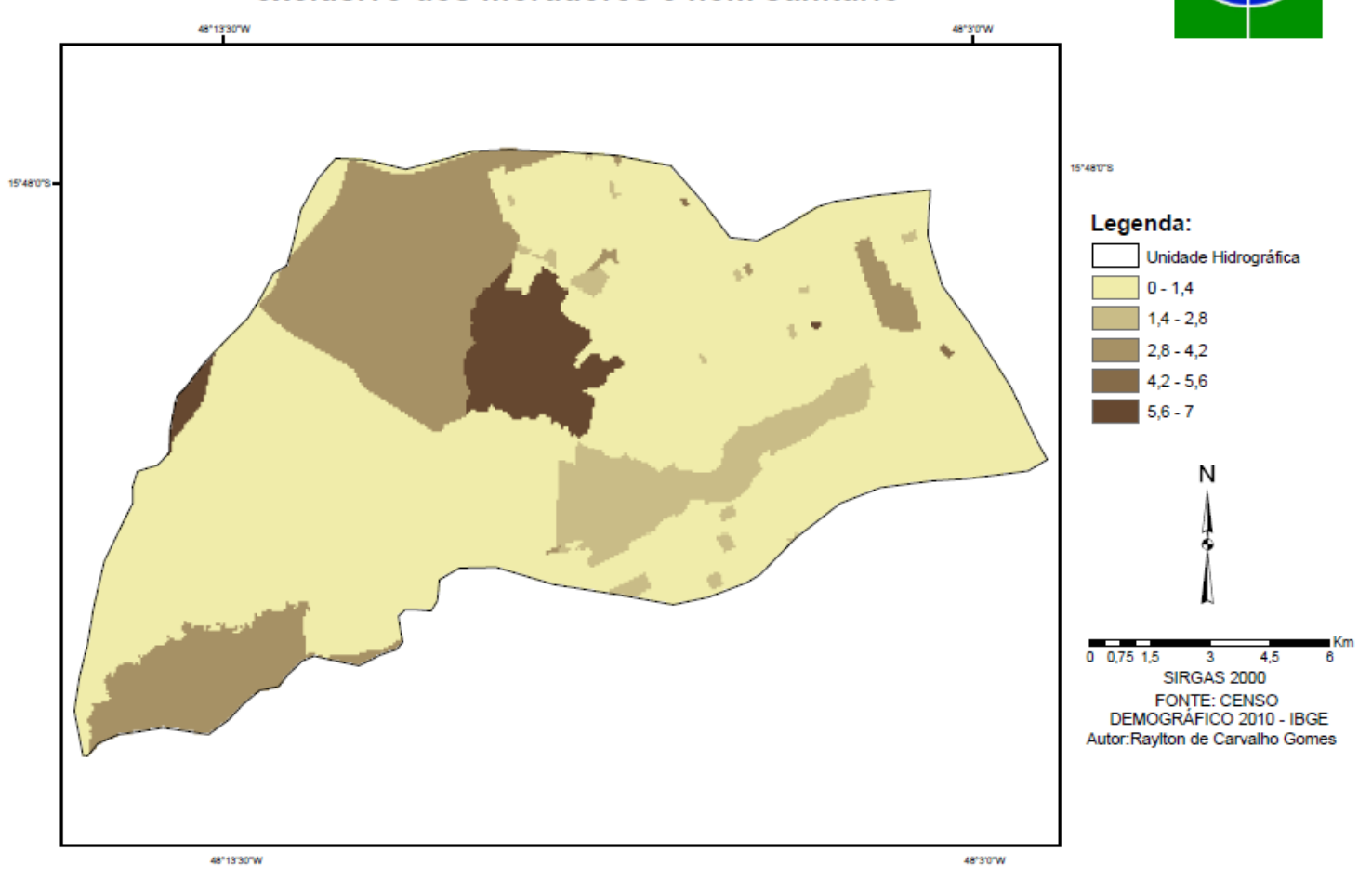

Figura 37: Domicílios particulares permanentes sem banheiro de uso exclusivo dos moradores e nem sanitário 


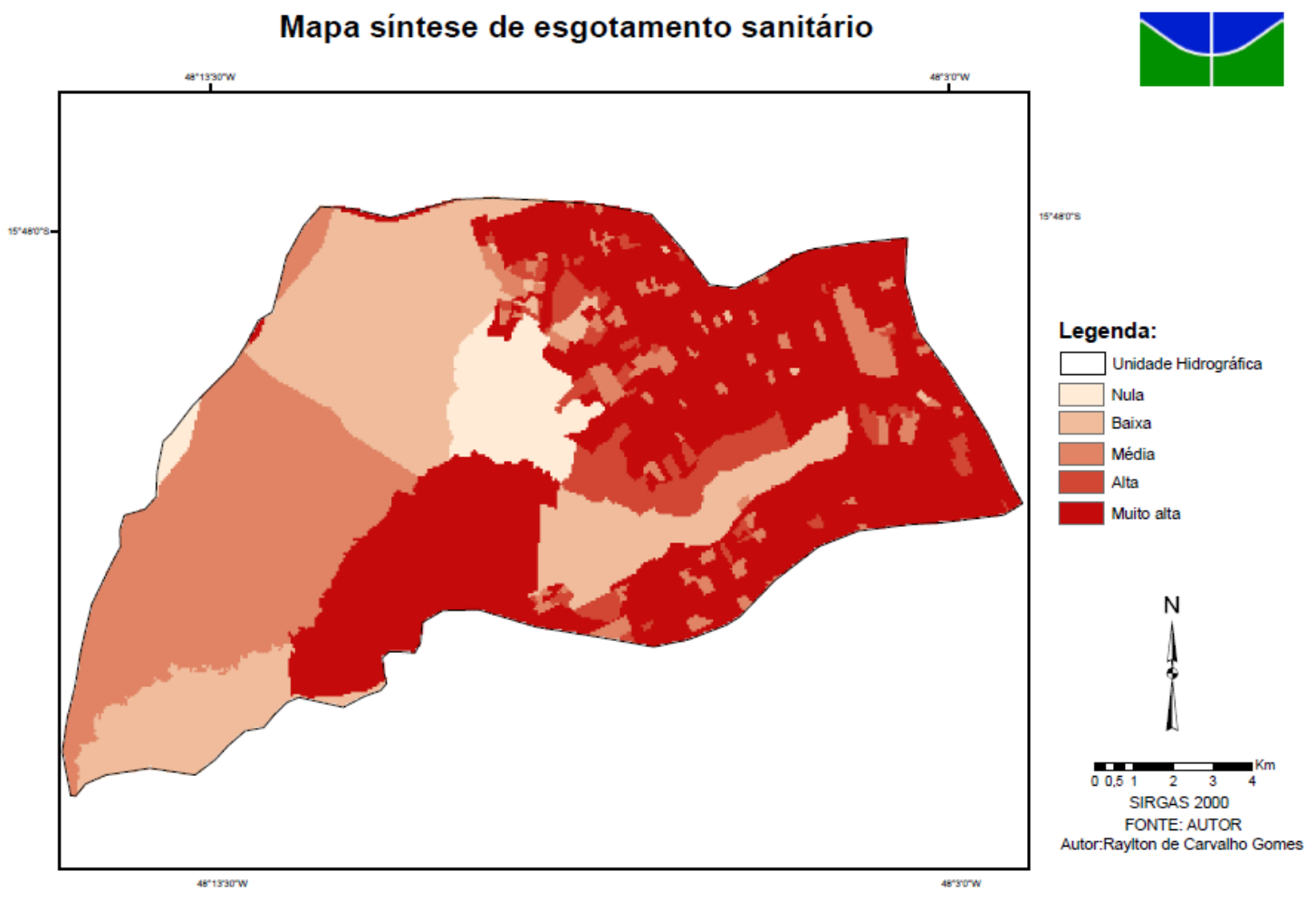

Figura 38: Mapa de síntese de esgotamento sanitário

Analisando os resultados demonstrados no mapa de integração dos dados do esgotamento sanitário (figura 38) é possível inferir que as áreas a noroeste da bacia, cujo adensamento urbano é mais significativo há o predomínio do esgotamento sanitário via rede geral de esgoto ou pluvial e do esgotamento via fossa séptica. Os métodos utilizados para coleta do esgoto em áreas urbanas demonstram ser mais eficazes, e com isso, esses desempenham menor influência em impactos ambientais causados na bacia em questão, apontando para a efetividade dos pesos definidos pelos especialistas e para estruturação do modelo AHP.

Já ao sudeste da bacia onde prevalecem as áreas rurais, verifica-se que há um número maior de domicílios com esgotamento sanitário destinado via outro escoadouro e fossas rudimentares, esses são os principais responsáveis pelo impacto provocado pelos esgotos sanitários, sem tratamento, lançados no córrego Melchior ou em solo, estando em consonância com os dados demostrados pelo Censo. 
Resíduos sólidos (figura 47). Para composição deste tema, foram utilizados 8 (oito) produtos, obtidos da base do censo do IBGE (2010). As figuras 39 a 46, apresentam o quadro atual da bacia.

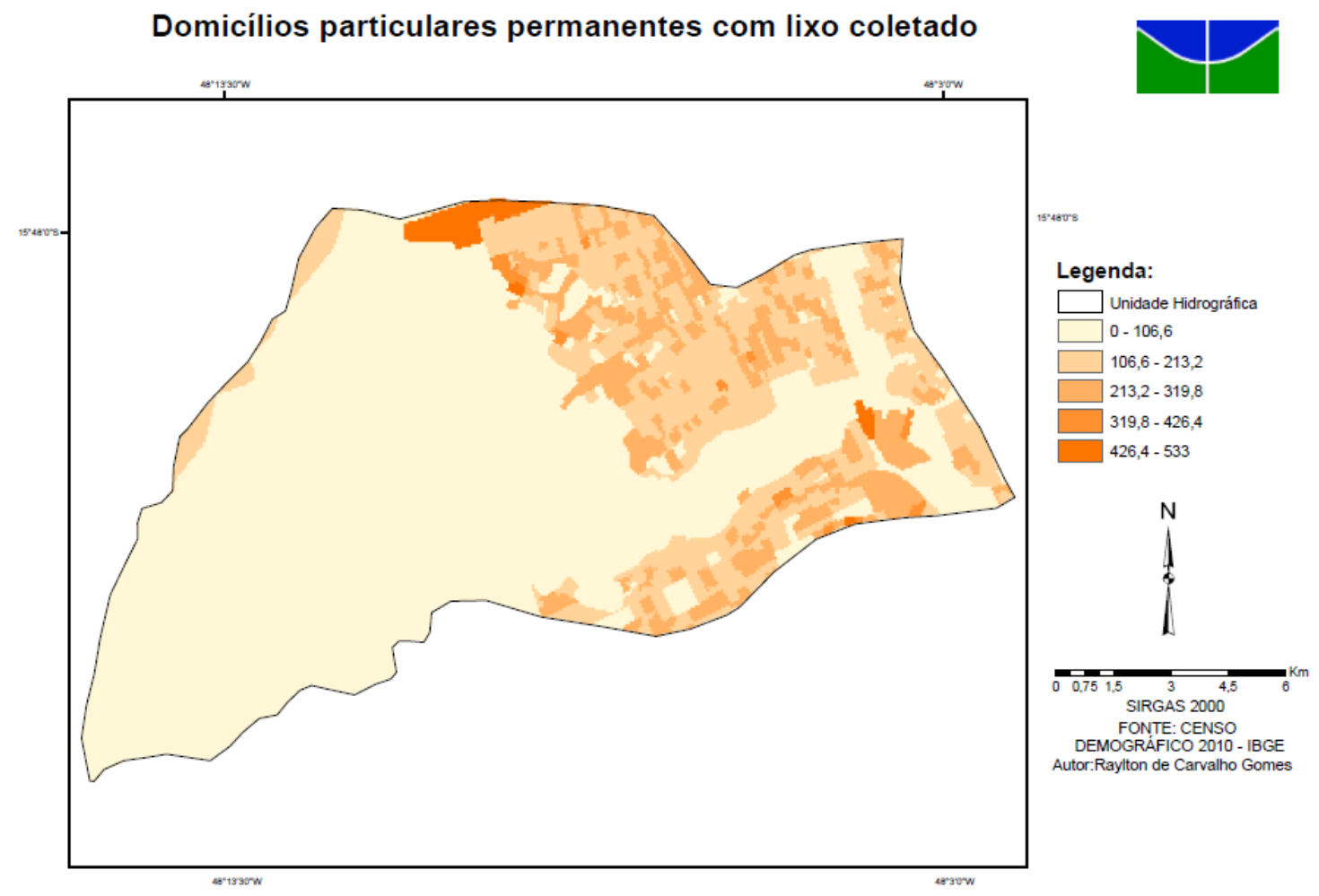

Figura 39: Domicílios particulares permanentes com lixo coletado 
Domicílios particulares permanentes com lixo coletado por serviço de limpeza

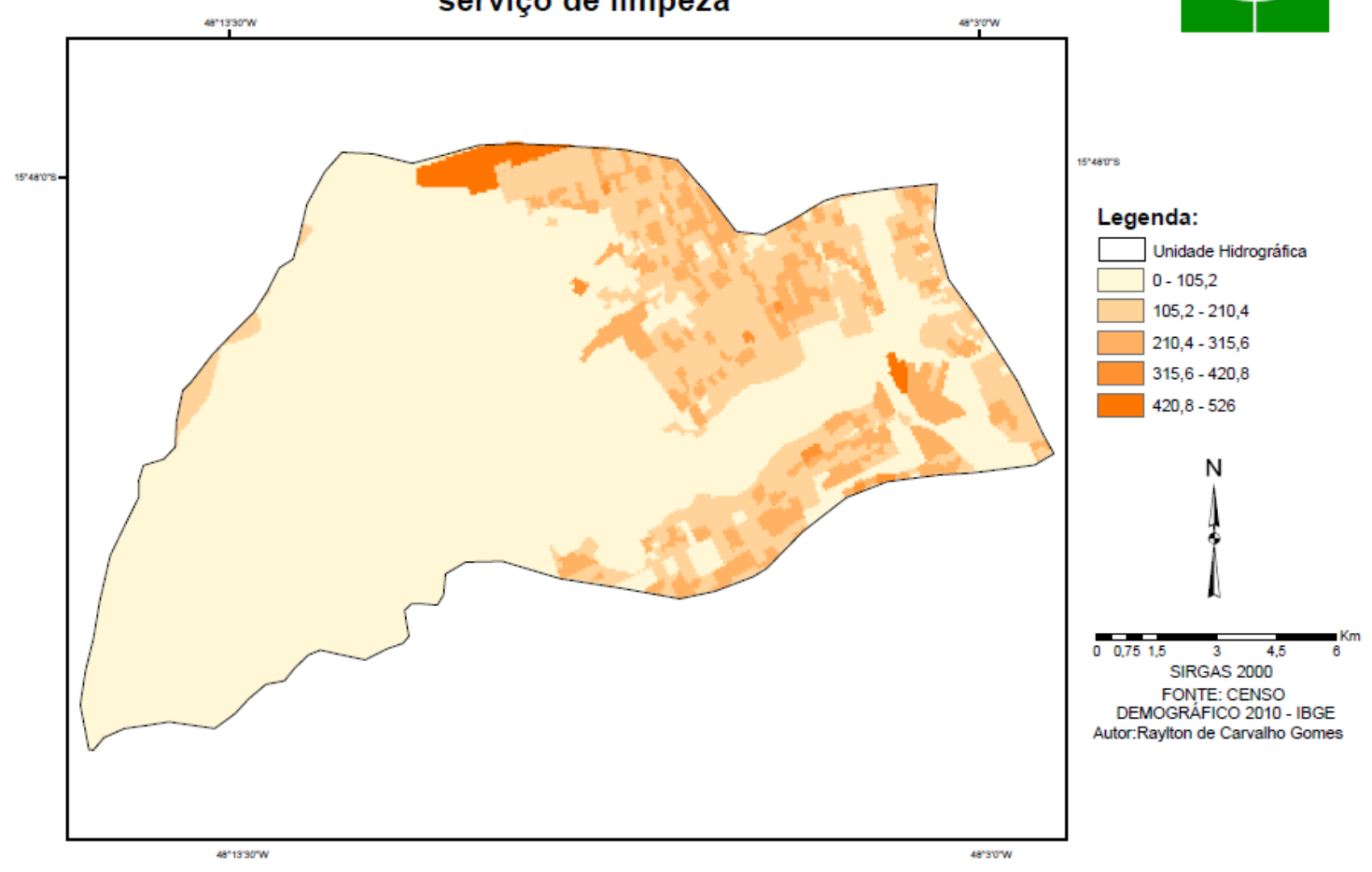

Figura 40: Domicílios particulares permanentes com lixo coletado por serviço de limpeza

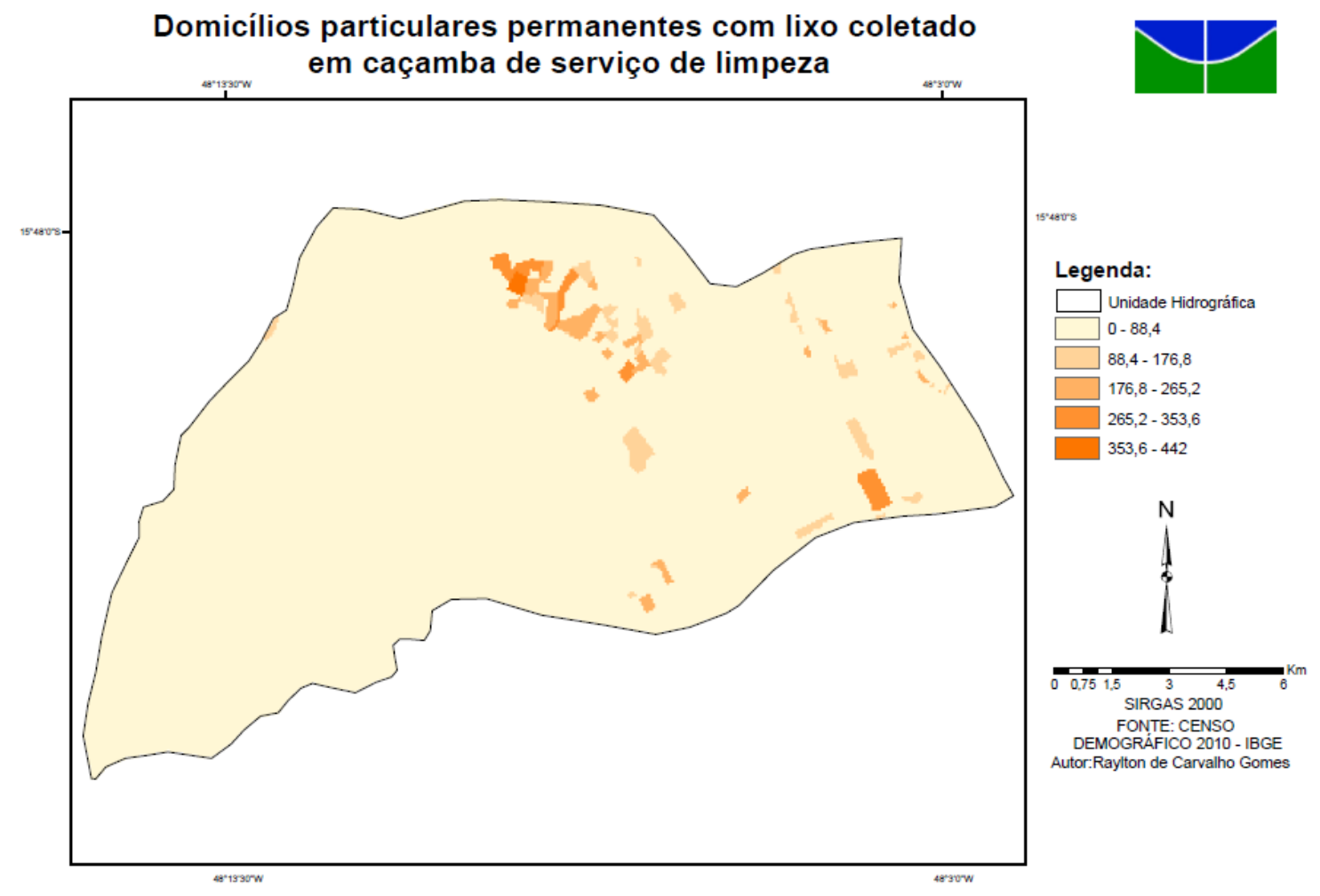

Figura 41: Domicílios particulares permanentes com lixo coletado em caçamba de serviço de limpeza 


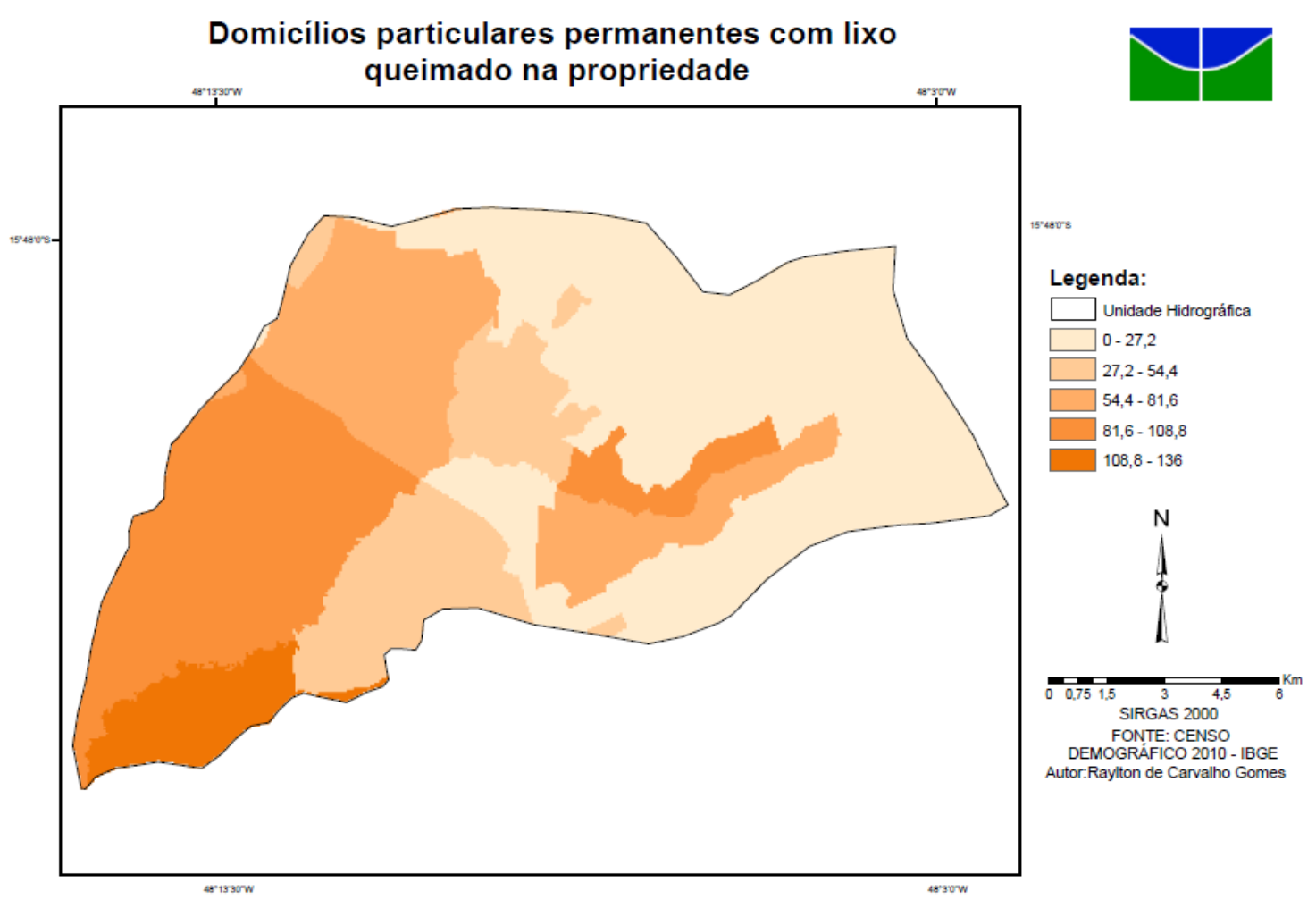

Figura 42: Domicílios particulares permanentes com lixo queimado na propriedade

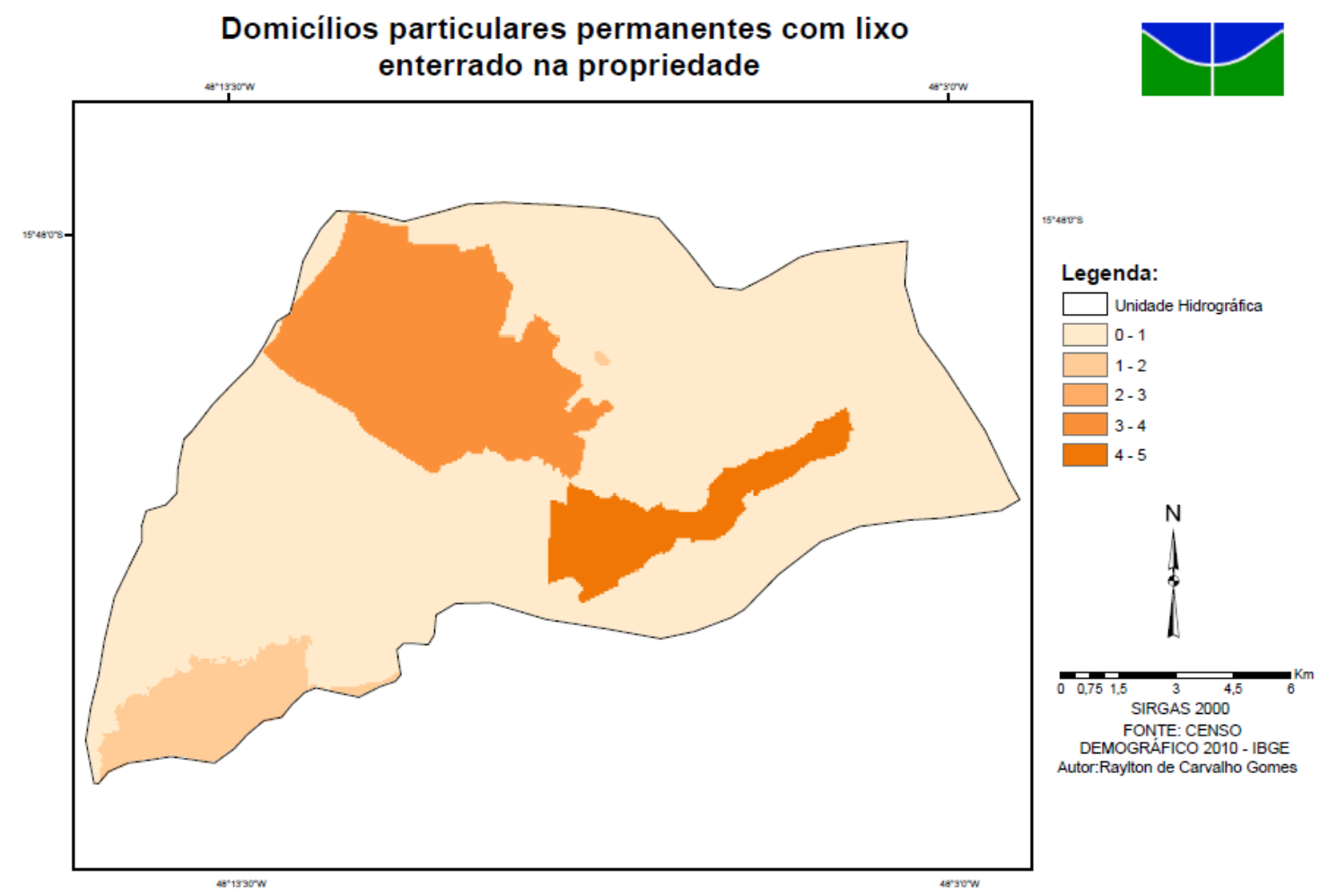

Figura 43: Domicílios particulares permanentes com lixo enterrado na propriedade 


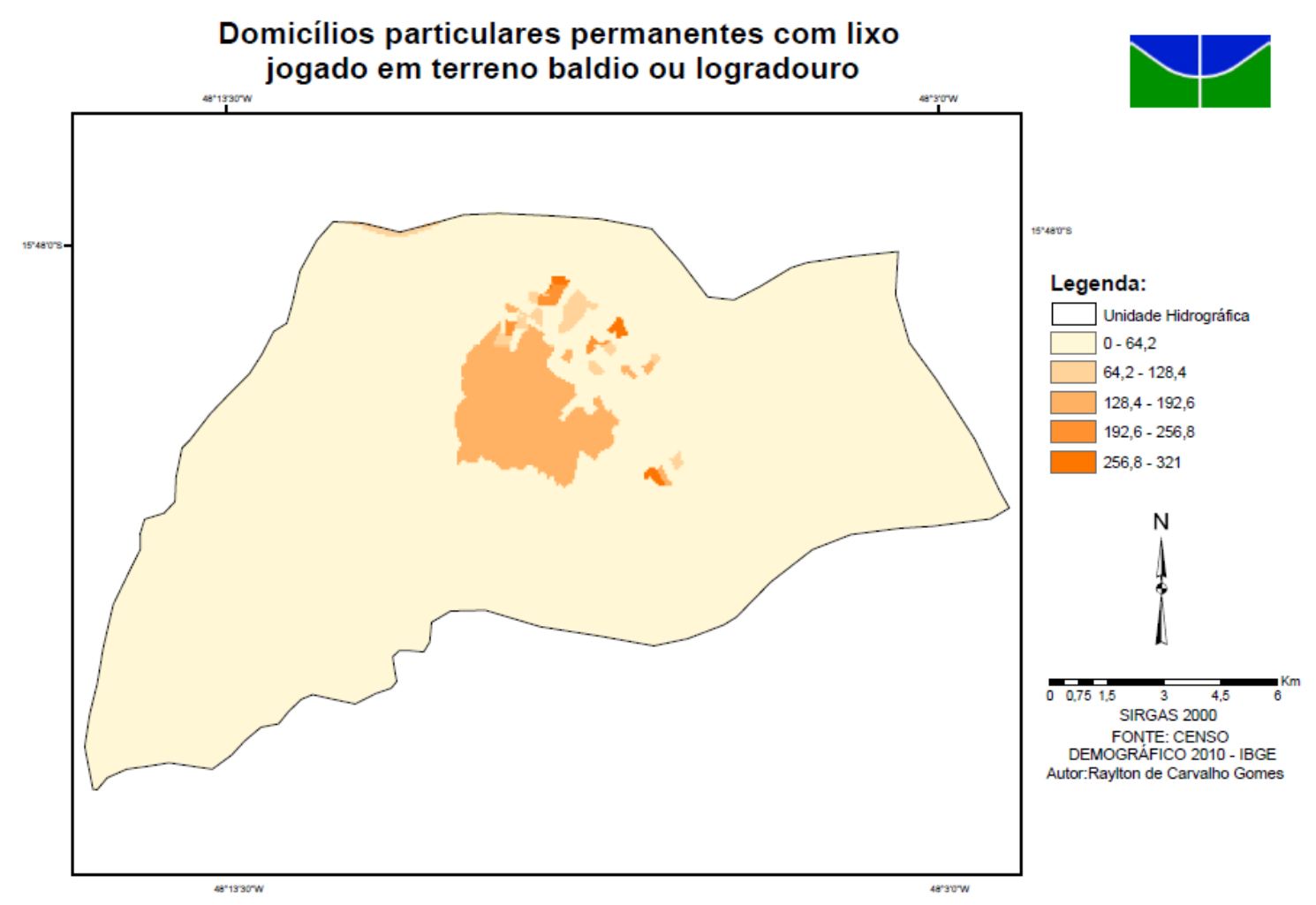

Figura 44: Domicílios particulares permanentes com lixo jogado em terreno baldio ou logradouro

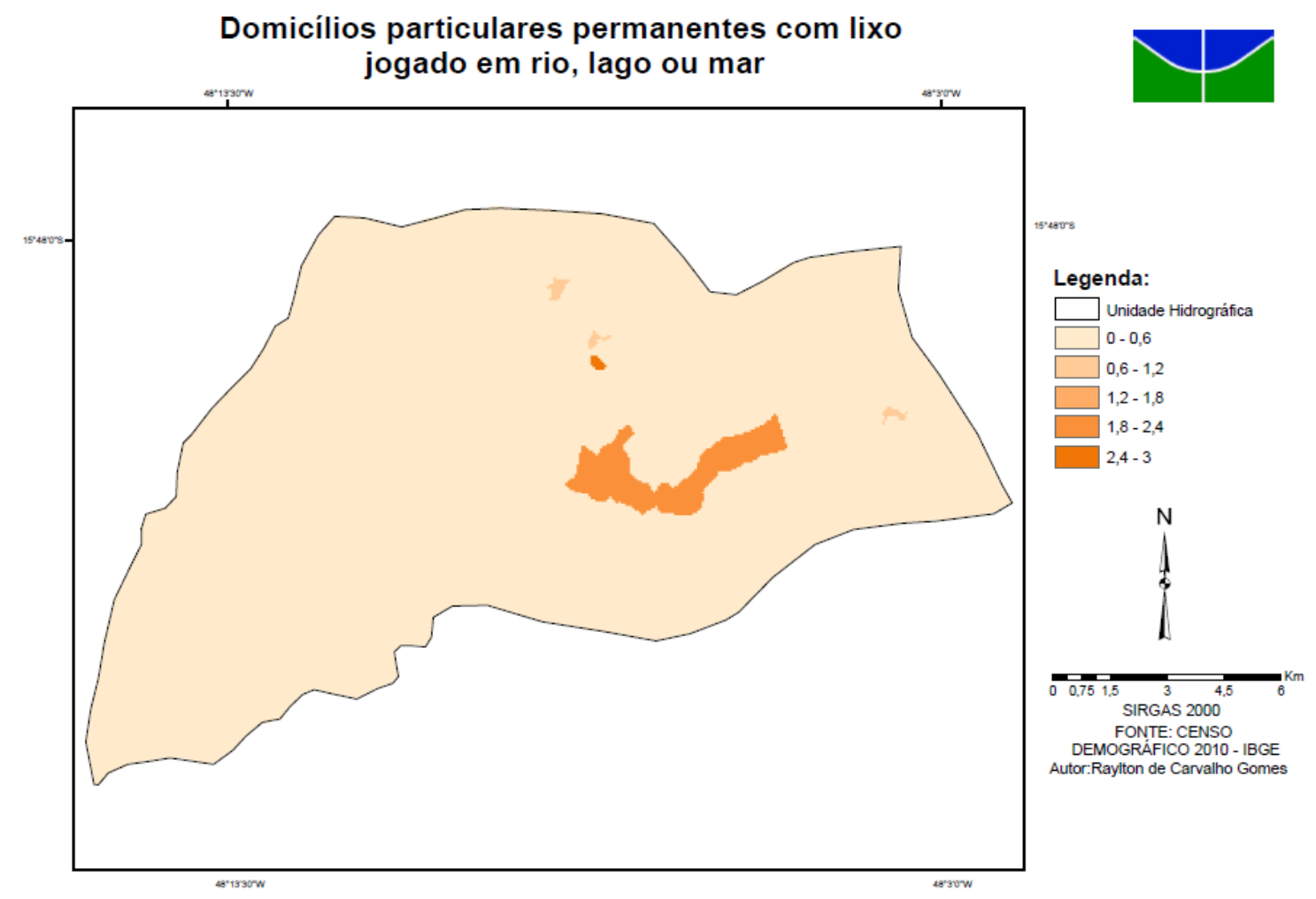

Figura 45: Domicílios particulares permanentes com lixo jogado em rio, lago ou mar 
Domicílios particulares permanentes com outro destino do lixo

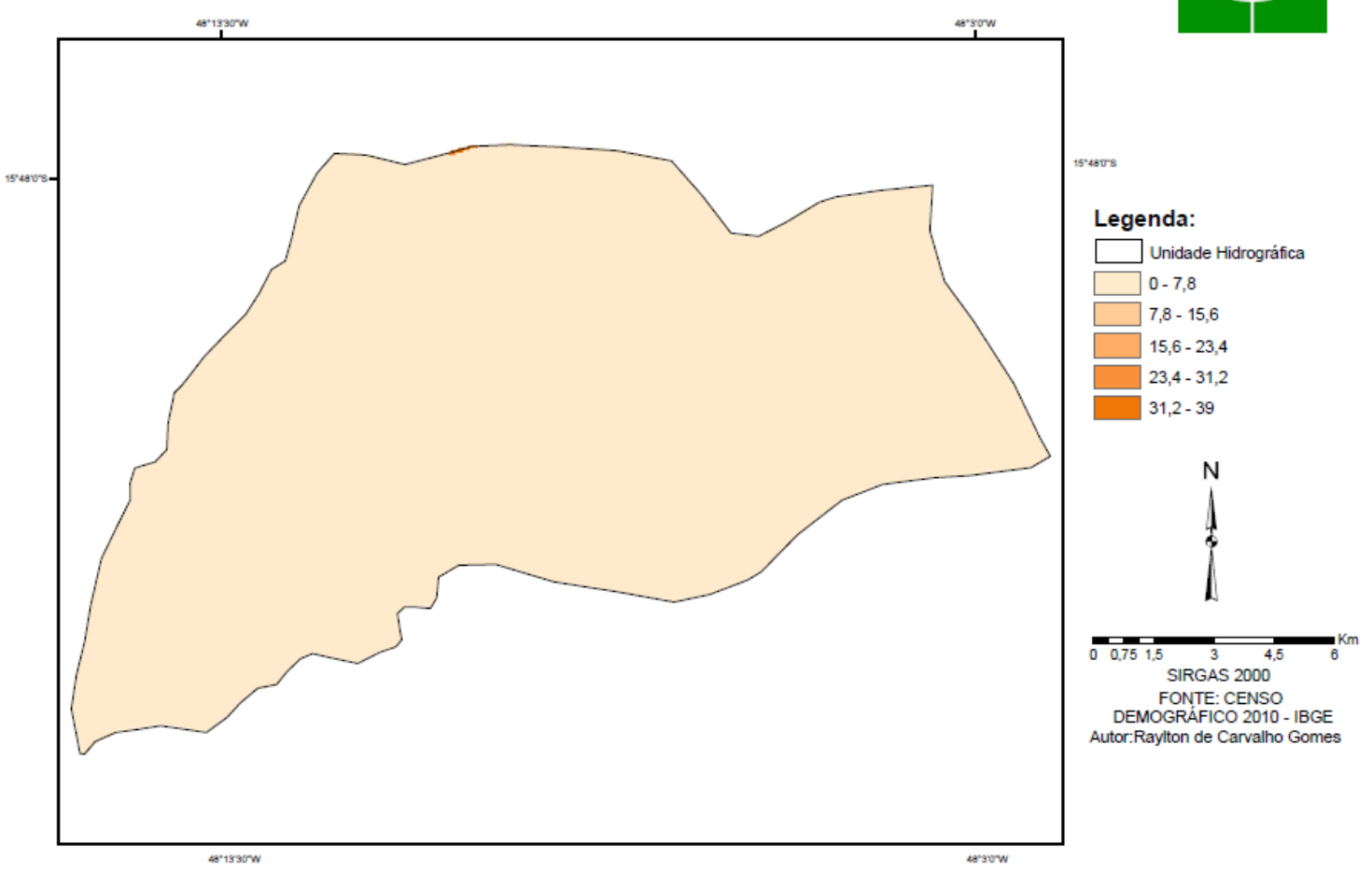

Figura 46: Domicílios particulares permanentes com outro destino do lixo

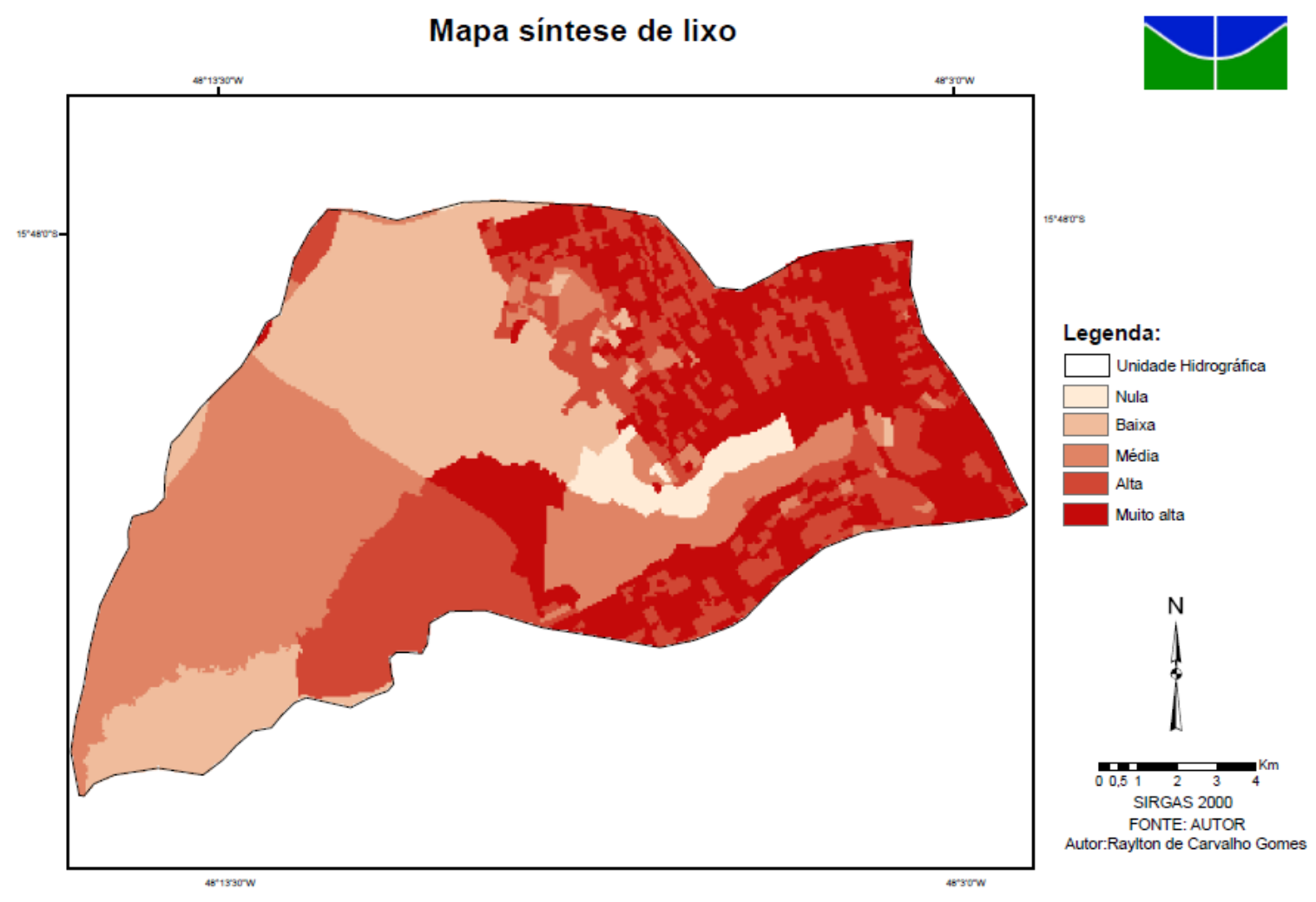

Figura 47: Mapa síntese de lixo 
O mapa de integração dos dados da destinação dos resíduos sólidos demonstra a relação do uso do solo e às formas de gestão dos resíduos. Ou seja, as áreas localizadas sudoeste da bacia tendem a predominar o meio rural, cuja destinação do lixo tem maior participação em rios, lagos, em terrenos baldios ou logradouros, queimados e enterrados na propriedade, isso se deve a ausência de uma gestão eficaz, além da falta de informação sobre as formas corretas de destinação do lixo.

Já nas áreas nordeste da bacia predominam as zonas urbanas onde a maior parte dos resíduos são coletados por serviço de limpeza, por empresas do governo e cooperativas no caso de lixos recicláveis.

Nas áreas urbanas temos um processo mais eficaz de gestão de resíduos em comparação com as áreas rurais, no entanto, as áreas urbanas são áreas com maior geração de resíduos em comparação com as áreas rurais, assim, tendo maior influência no nível de qualidade ambiental, dados que corroboram com os estruturados no modelo e no AHP e descritos pelo Censo.

Água potável (figura 52). Para composição deste tema, foram utilizados 4 (quatro) produtos, obtidos da base do censo do IBGE (2010) (figuras 48 a 51).

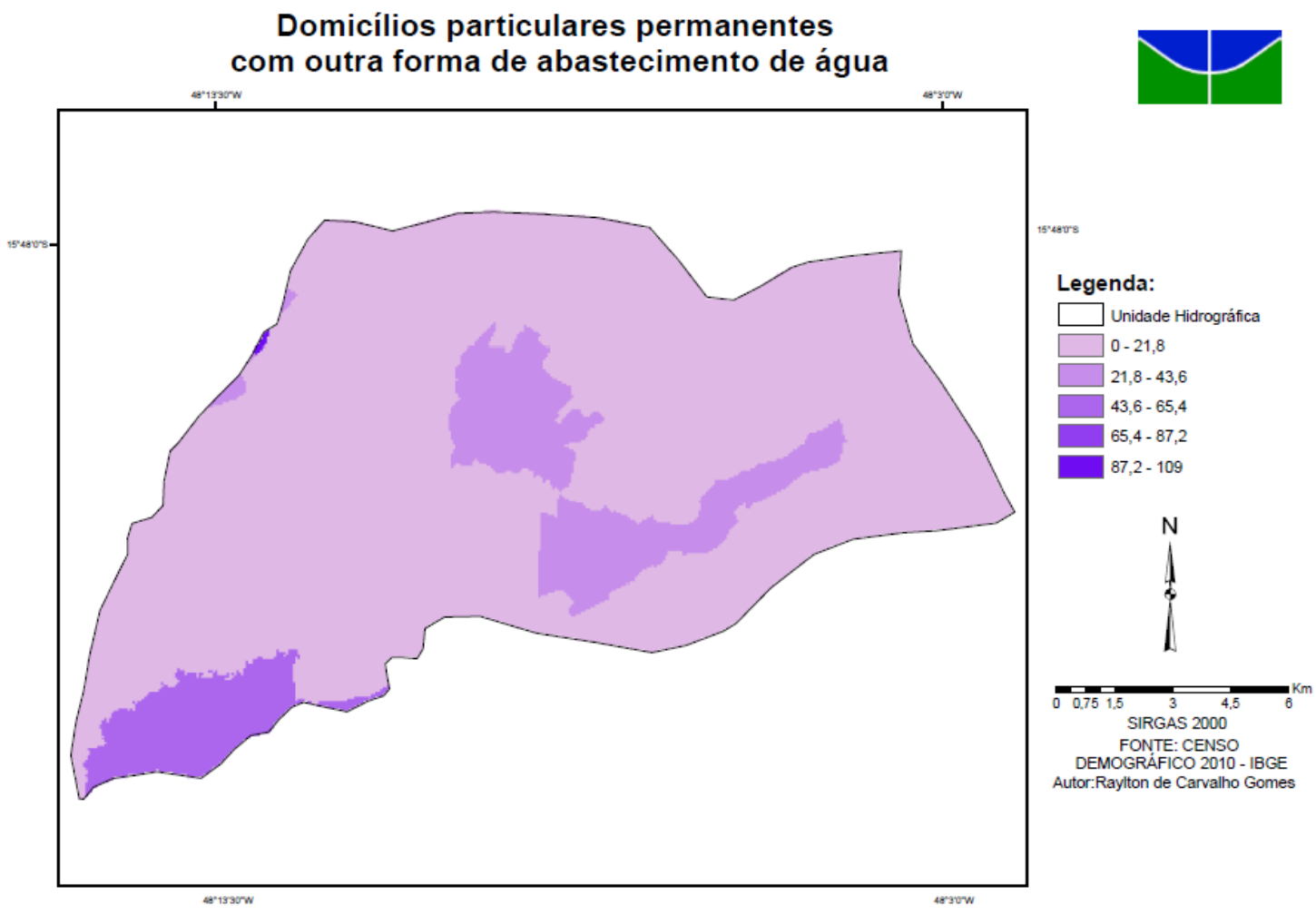

Figura 48: Domicílios particulares permanentes com outra forma de abastecimento de água 


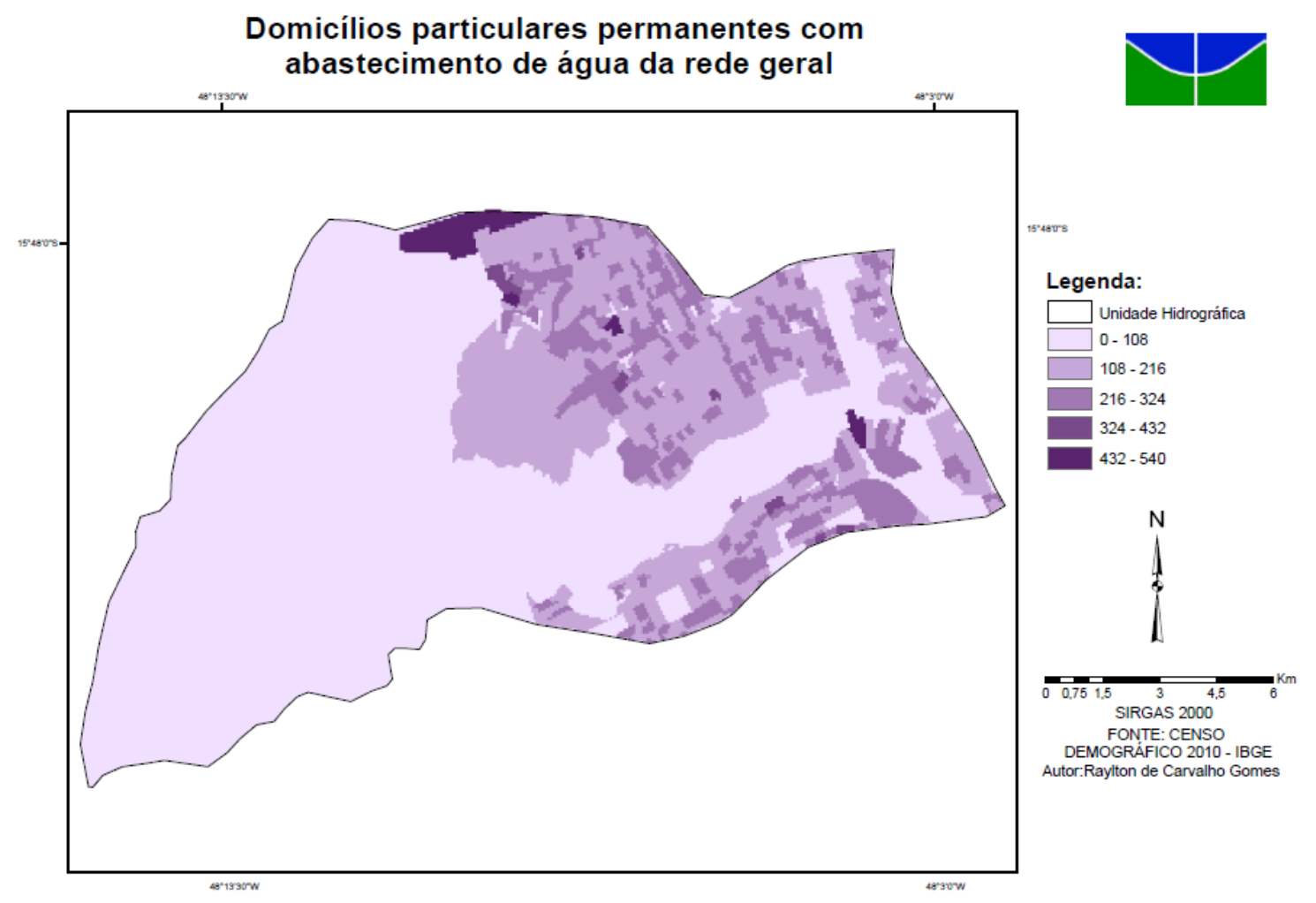

Figura 49: Domicílios particulares permanentes com abastecimento de água de rede geral

Domicílios particulares permanentes com abastecimento de água da chuva armazenada em cisterna

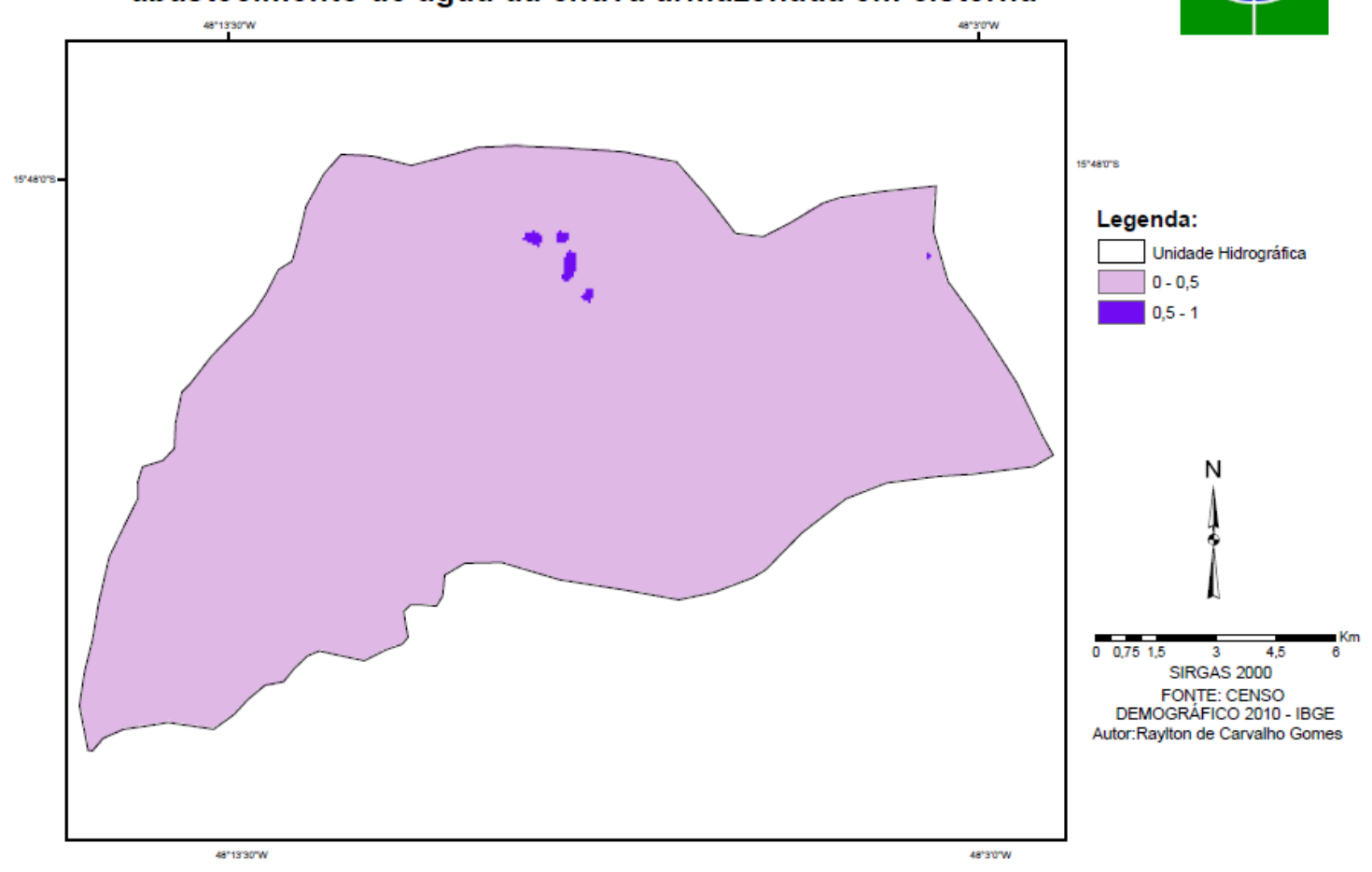

Figura 50: Domicílios particulares permanentes com abastecimento de água da chuva armazenada em cisterna 


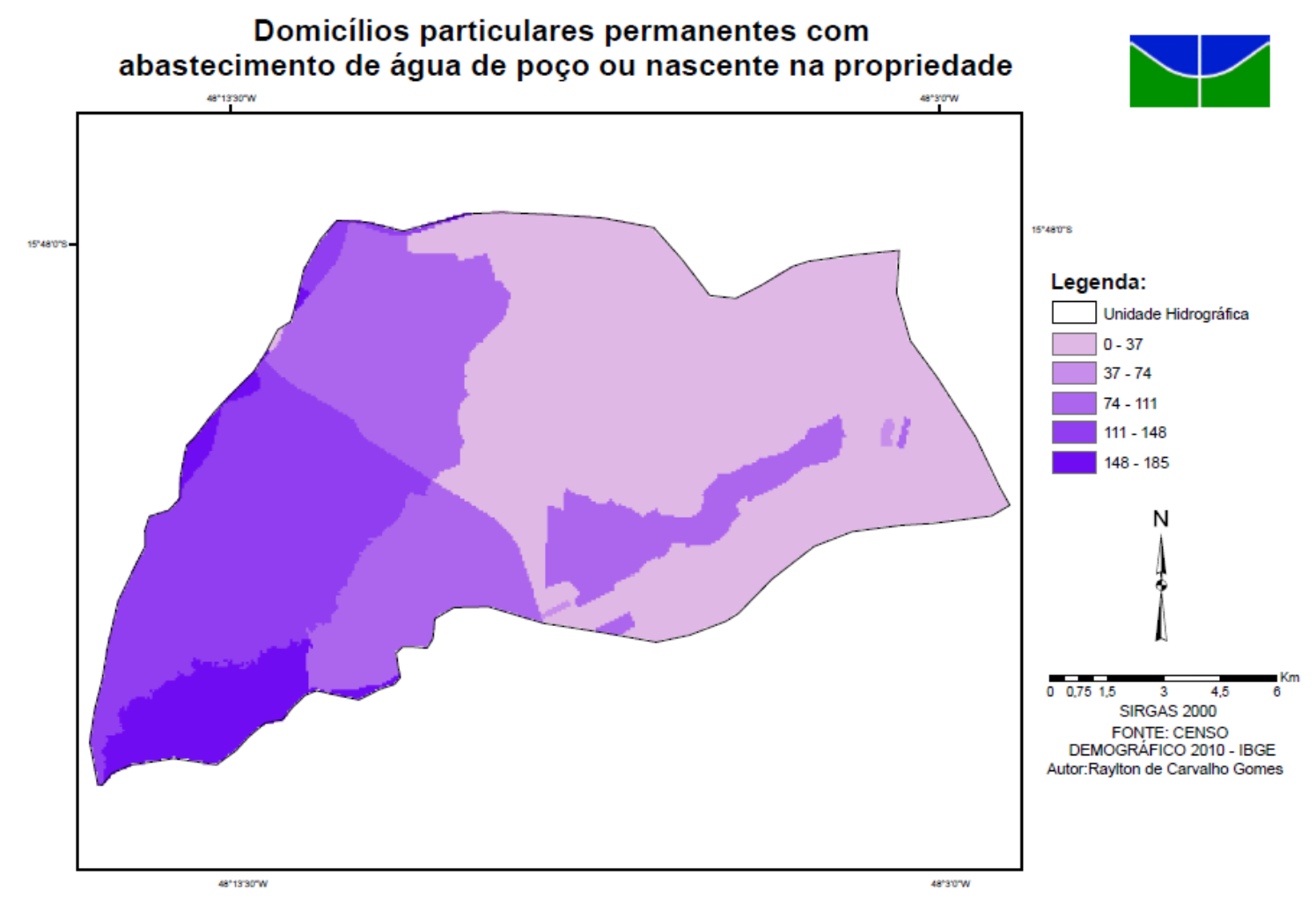

Figura 51: Domicílios particulares permanentes com abastecimento de água de poço ou nascente na propriedade

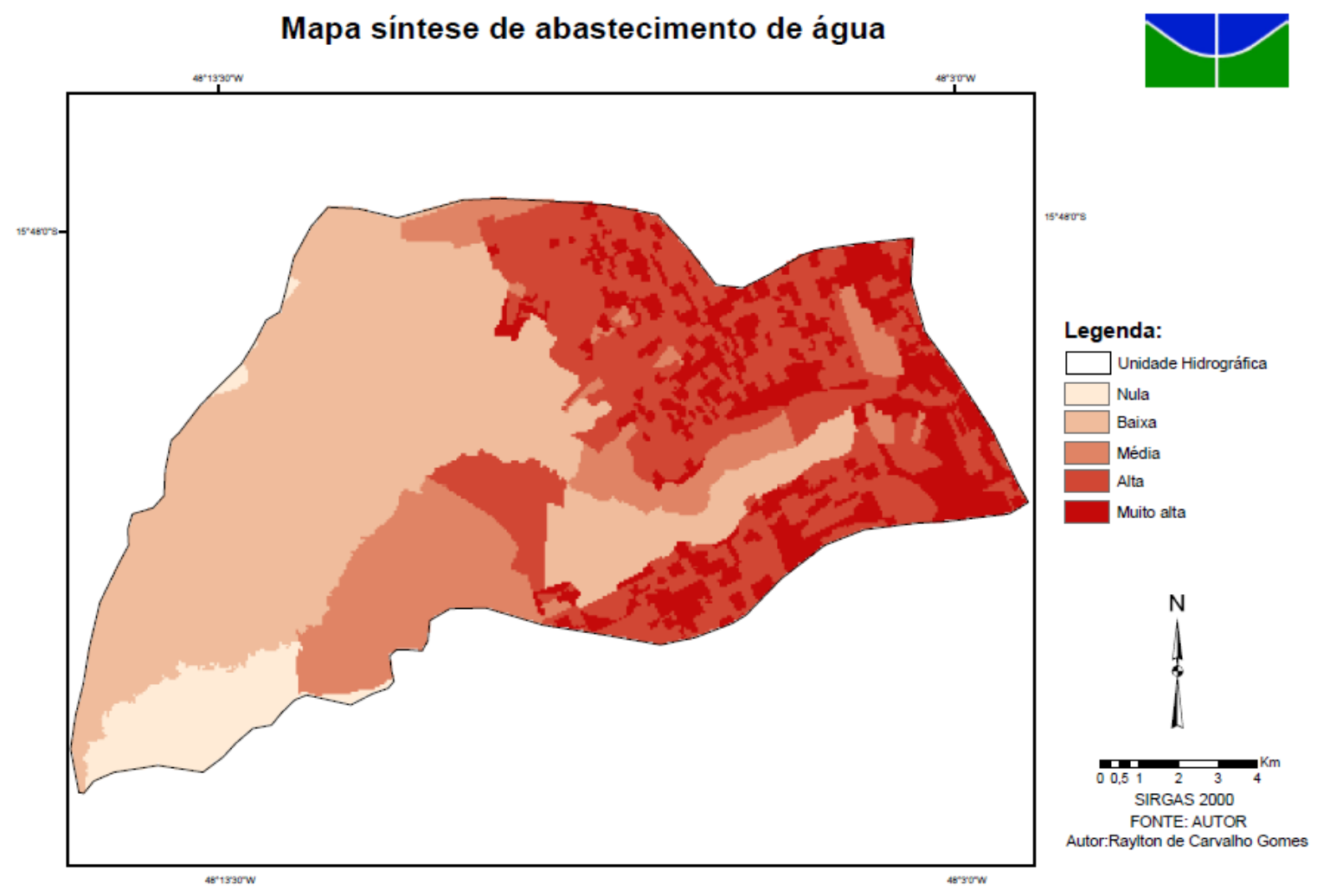

Figura 52: Mapa síntese de abastecimento de água 
Com relação ao mapa de integração dos dados de abastecimento de água (Figura 52) foi possível analisar que na zona rural (predominante na área sudoeste da bacia) o abastecimento de água é realizado por meio da chuva e armazenado em cisterna e através de poço ou nascente na propriedade.

Já a parte nordeste da bacia, área mais urbanizada, verifica-se que a população faz o uso da rede geral de água, fornecida pela empresa de abastecimento responsável pela distribuição de água no Distrito Federal, que é a CAESB.

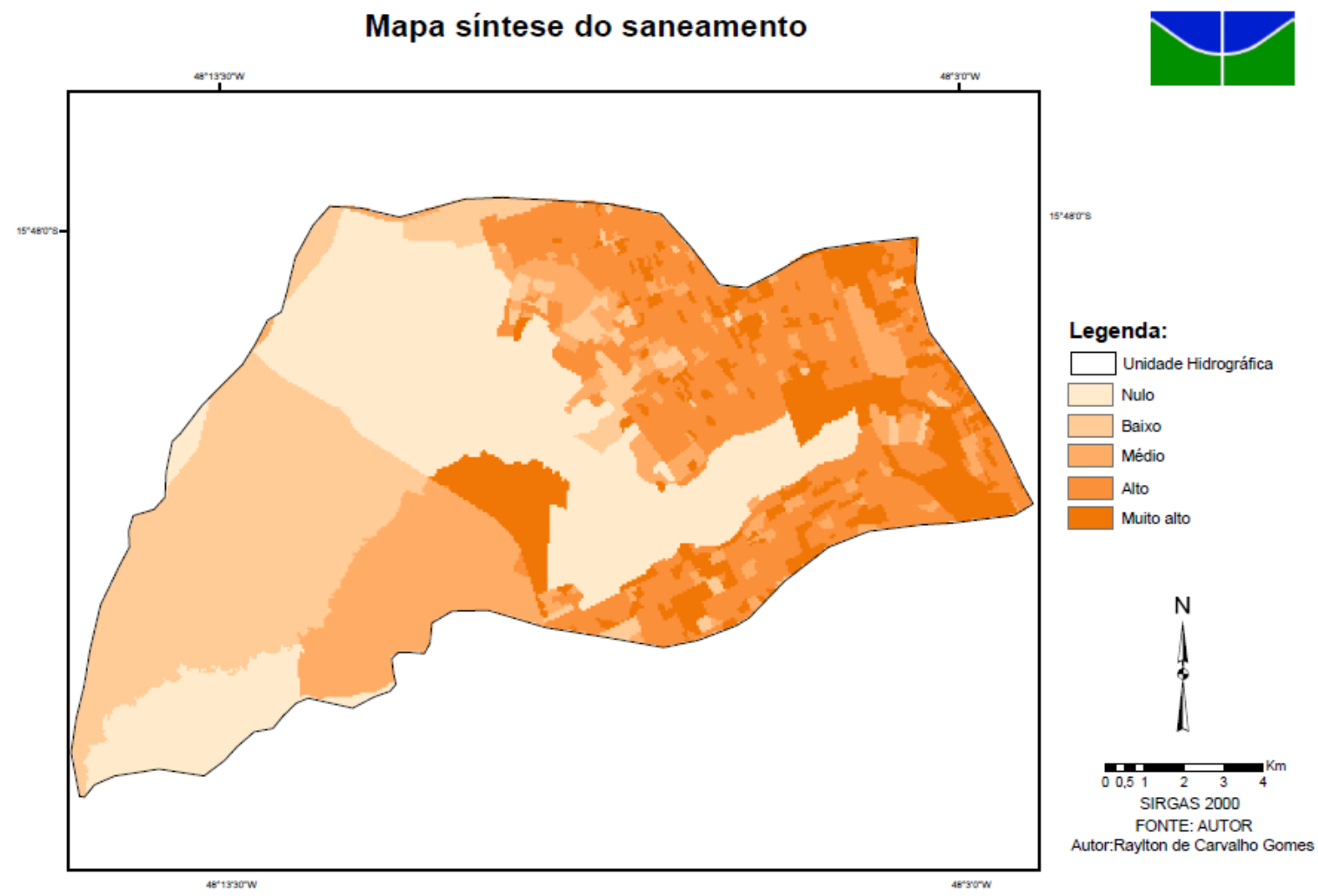

Figura 53: Mapa síntese do saneamento

De acordo com o figura 53, é possível verificar que as áreas a noroeste da bacia, cujo adensamento urbano é mais significativo com cerca de $30 \%$ da área, prevaleceu o nível de qualidade muito alto e alto, esse fato pode ser explicado, devido, às áreas urbanizadas que possuem métodos eficazes para a coleta do esgoto, do lixo e do abastecimento de água, desempenhando menor influência em impactos ambientais causados na bacia em questão, apontando para a efetividade dos pesos definidos pelos especialistas e para estruturação do modelo AHP. 
Verifica-se que a sudeste e na área central da bacia com 65\% da área, prevaleceu o nível de qualidade médio e baixo, com um número maior de domicílios em áreas rurais, esses são os principais responsáveis pelo impacto provocado pelos esgotos sanitários, sem tratamento, lançados no córrego Melchior ou em solo, lixo jogado em terreno baldio ou logradouros, enterrado ou queimado na propriedade, jogado em rio, estando em consonância com os dados demostrados pelo Censo.

Por fim, a área central da bacia predomina o nível de qualidade muito alto com $5 \%$ de representatividade, sendo uma área rural, com poucos domicílios, com menor geração de resíduos e esgotamento sanitário, classificada como área com o nível de qualidade muito alto e alto nos mapas de integração do abastecimento de água, esgoto e destinação dos resíduos sólidos conforme figura 38, 47 e 52. A figura 54 apresenta uma área conservada, comprovando a eficiência do modelo e julgamento de pesos AHP.

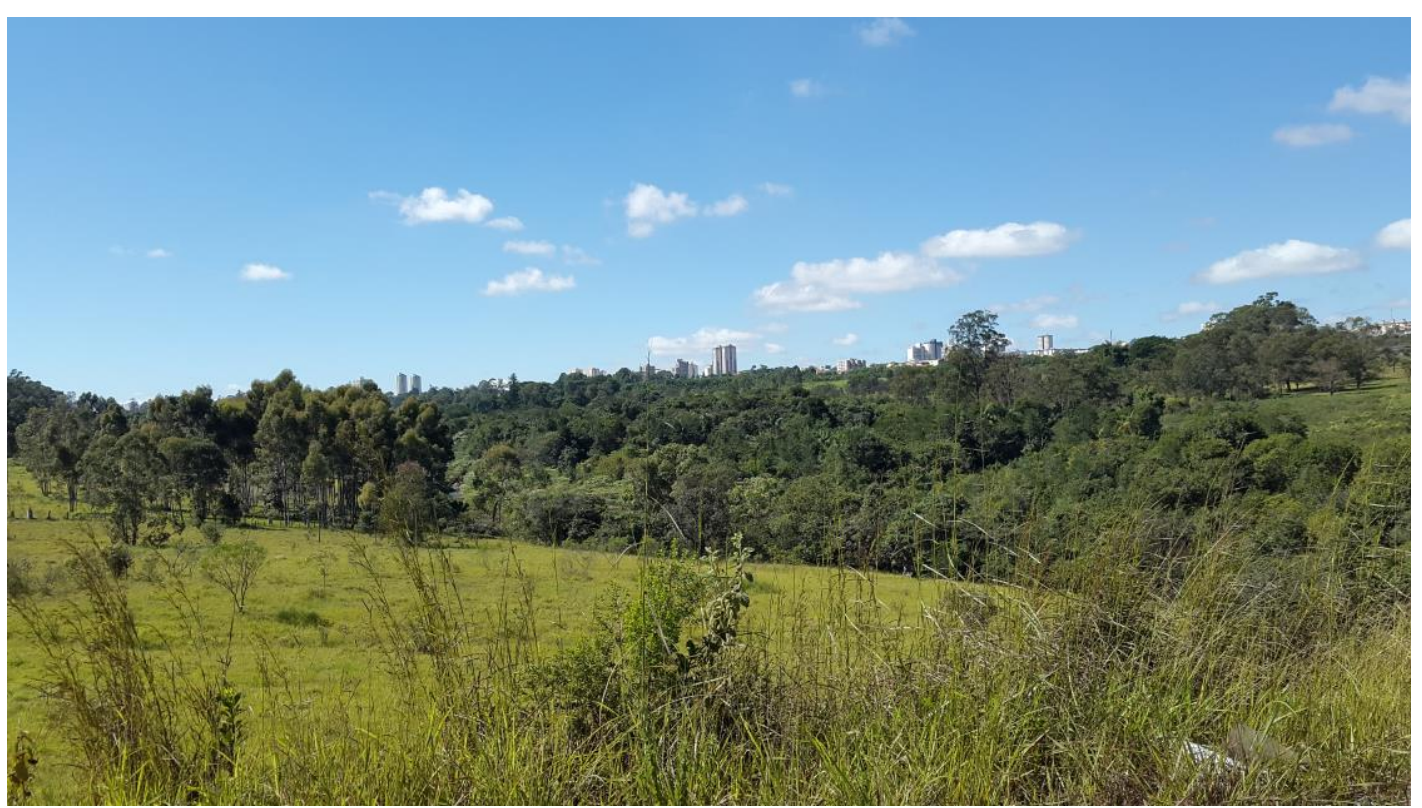

Figura 54: Áreas com maior nível de qualidade ambiental

\subsection{MAPA DO NÍVEL DE QUALIDADE AMBIENTAL DA BACIA DO MELCHIOR}

Assim, após o processo de modelagem em SIG, tendo como entrada os pesos e os dados geográficas de cada tema foi elaborado o mapa do Nível de Qualidade Ambiental da Bacia do Melchior (Figura 55). 
Na elaboração do mapa do Nível de Qualidade Ambiental da Bacia do Melchior, destacam-se com maior relevância os seguintes elementos:

- Mapa de integração do meio físico com peso 0,667;

- Mapa de integração do saneamento com peso de 0,333.

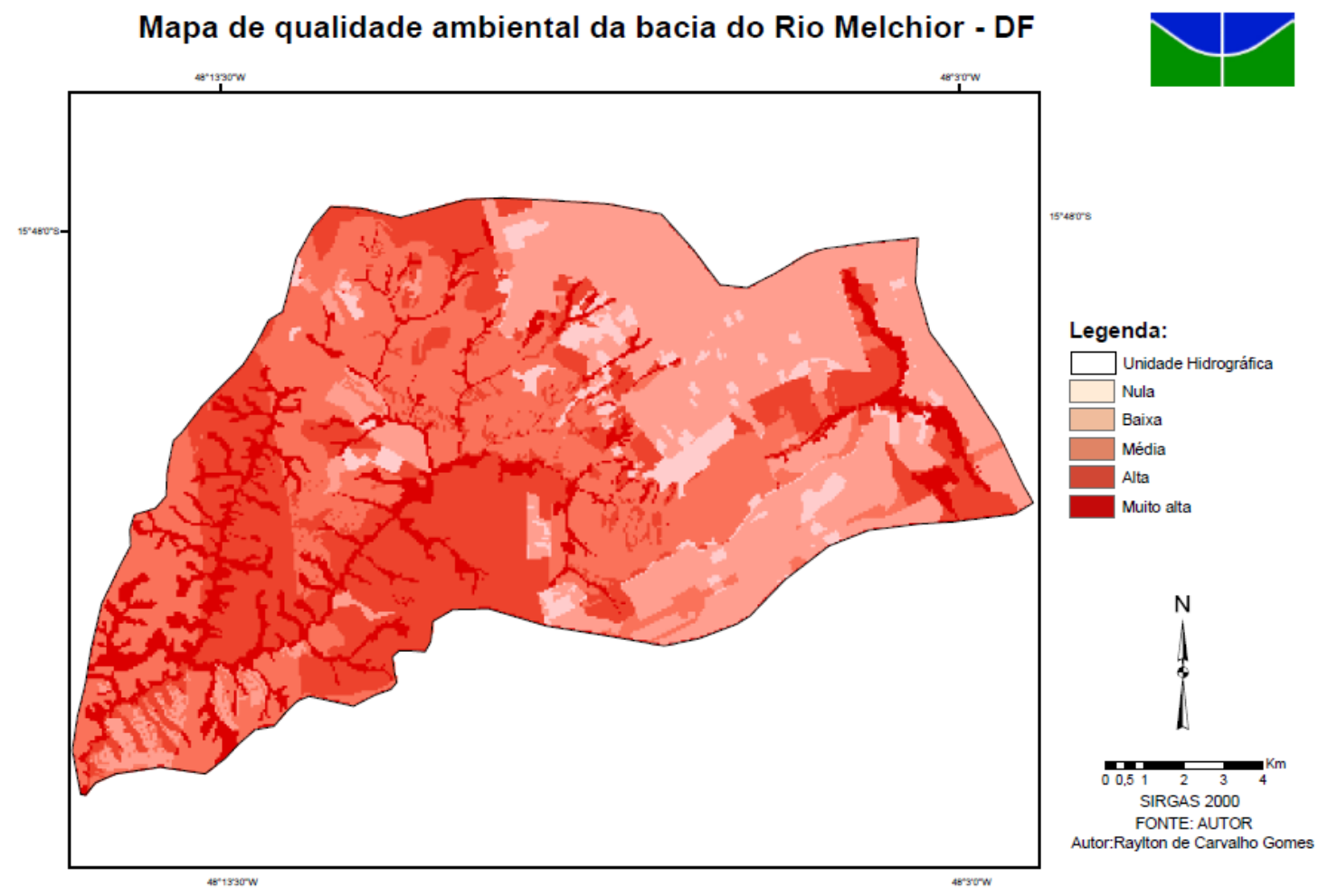

Figura 55: Mapa de qualidade ambiental da bacia do Rio Melchior - DF

Algumas considerações devem ser apontadas com relação ao meio físico e saneamento e a sua influência na bacia e que são analisadas a partir de sua integração,

$\mathrm{Na}$ figura 58 analisaram-se os seguintes aspectos:

- $9 \%$ da bacia foi classificada com o nível de qualidade ambiental nula;

- $25 \%$ da bacia foi classificada com o nível de qualidade ambiental baixa;

- $29 \%$ da bacia foi classificada com o nível de qualidade ambiental média;

- $24 \%$ da bacia foi classificada com o nível de qualidade ambiental alta;

- $13 \%$ da bacia foi classificada com o nível de qualidade ambiental muito alta.

Destaca-se a área nordeste da bacia como a área que tem os níveis de qualidade ambiental nulo, apresenta uma grande fragilidade ambiental e nela estão as maiores extensões de ocupação urbana sem infraestrutura, bem como os maiores índices de consumo de água, 
geração dos resíduos sólidos e lançamento de esgoto inadequado, conforme apresentado nas figuras 56 e 57.

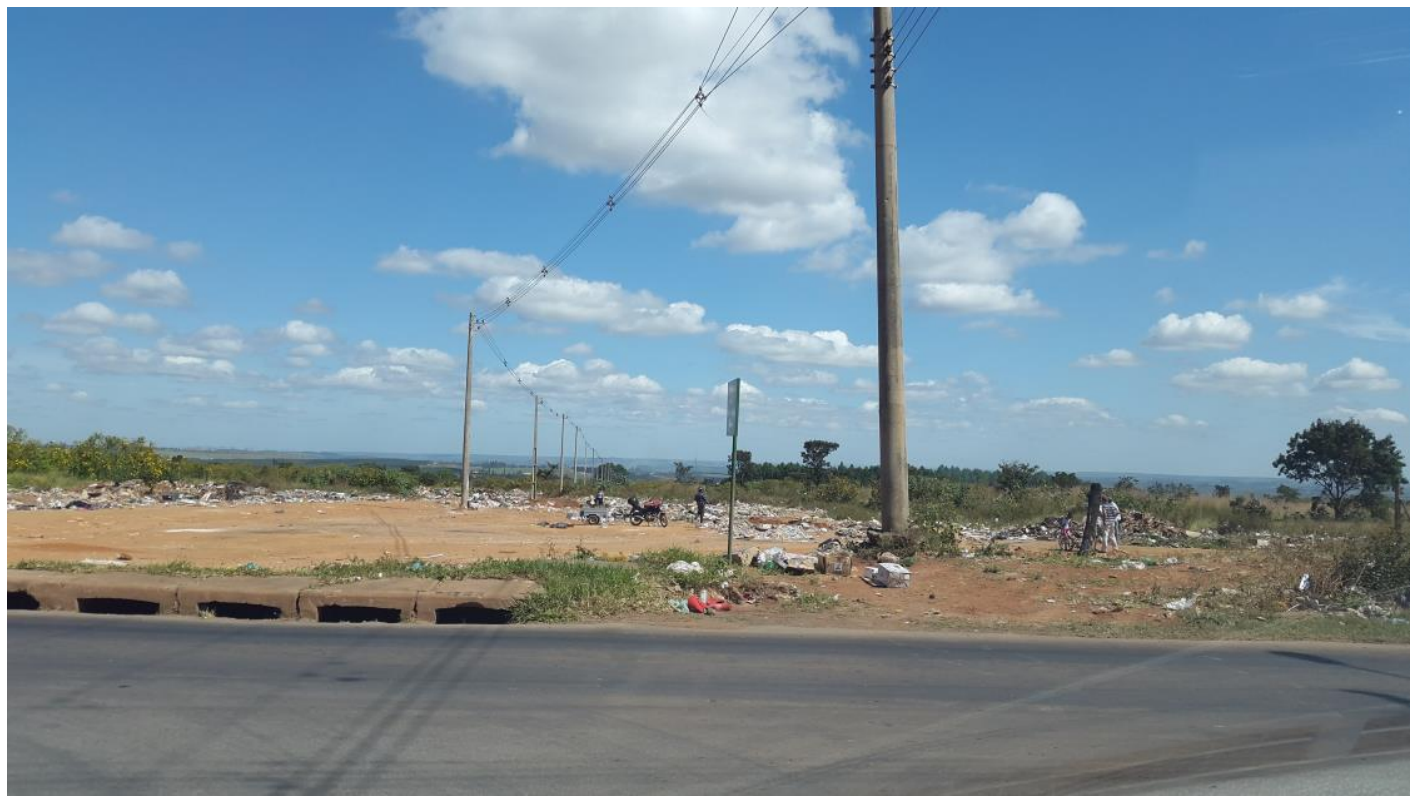

Figura 56: Falta de infraestrutura e descarte inadequado de resíduos

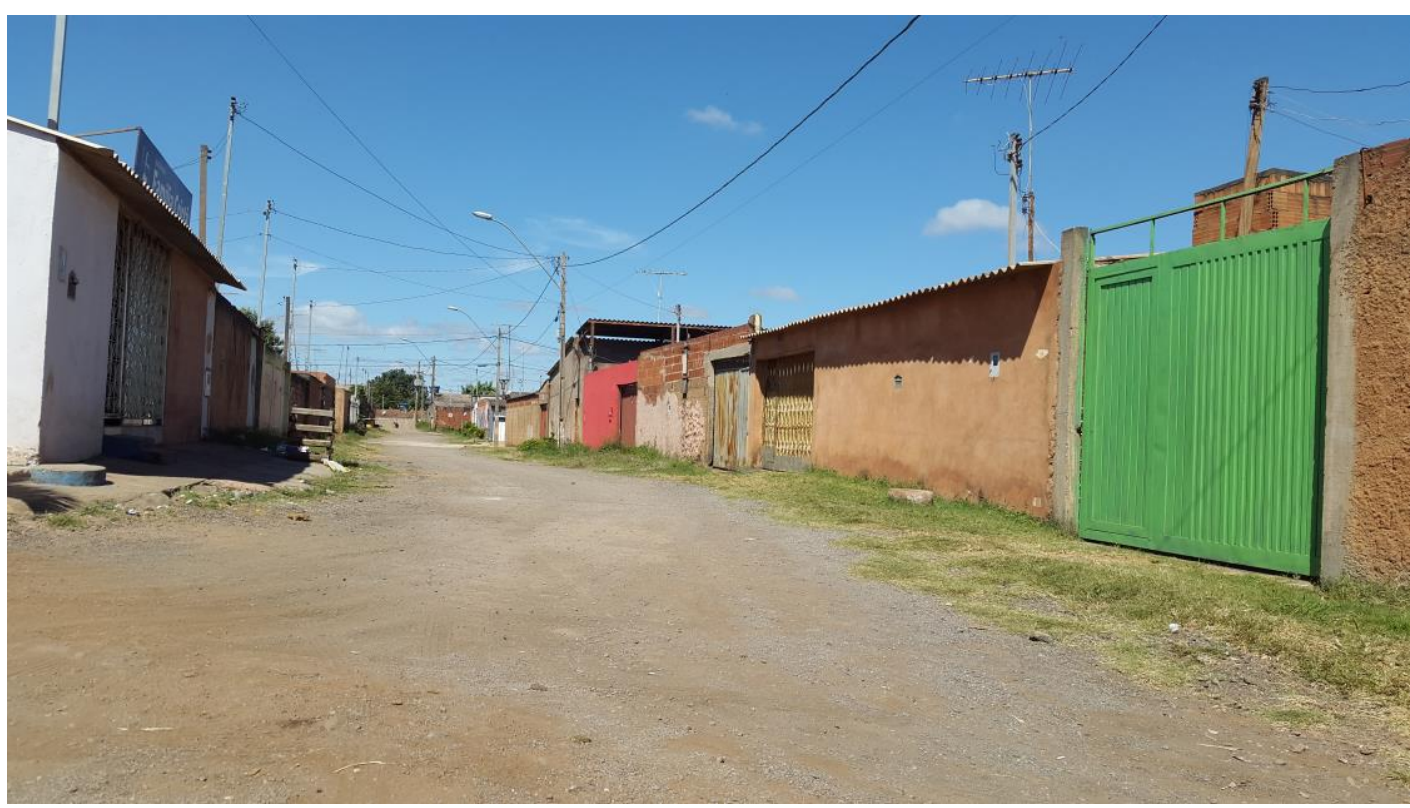

Figura 57: Falta de infraestrutura

Observa-se também que as áreas urbanizadas localizadas na área noroeste da bacia foram classificadas com o nível de qualidade ambiental baixo, pode ser explicada, pelo fato das áreas urbanas terem sido classificadas no modelo como áreas com infraestrutura (figura 58) e sem infraestrutura, essa diferença refletiu no nível de qualidade ambiental da bacia. 


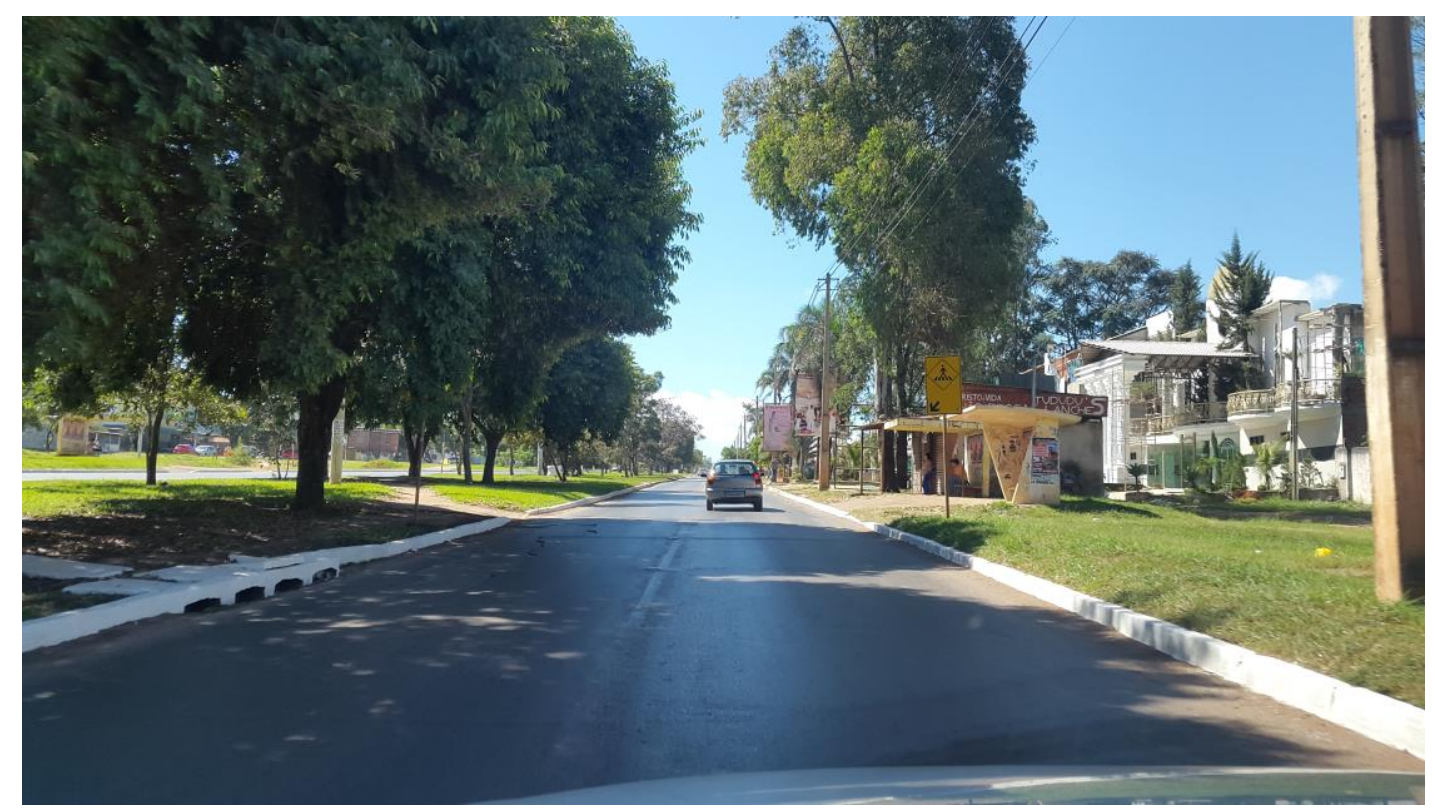

Figura 58: Áreas com infraestrutura

Ainda na análise da área nordeste, observa-se que entre as cidades satélites de Ceilândia, de Samambaia e de Taguatinga, classificadas com o nível de qualidade ambiental muito alto, alto e médio (figura 59), este fato pode ser explicado, por nessas áreas estarem localizados, áreas rurais e parques (figura 60) onde predominam as áreas verdes, que são utilizados na maioria das vezes para o lazer da população (Figura 61 e 62).

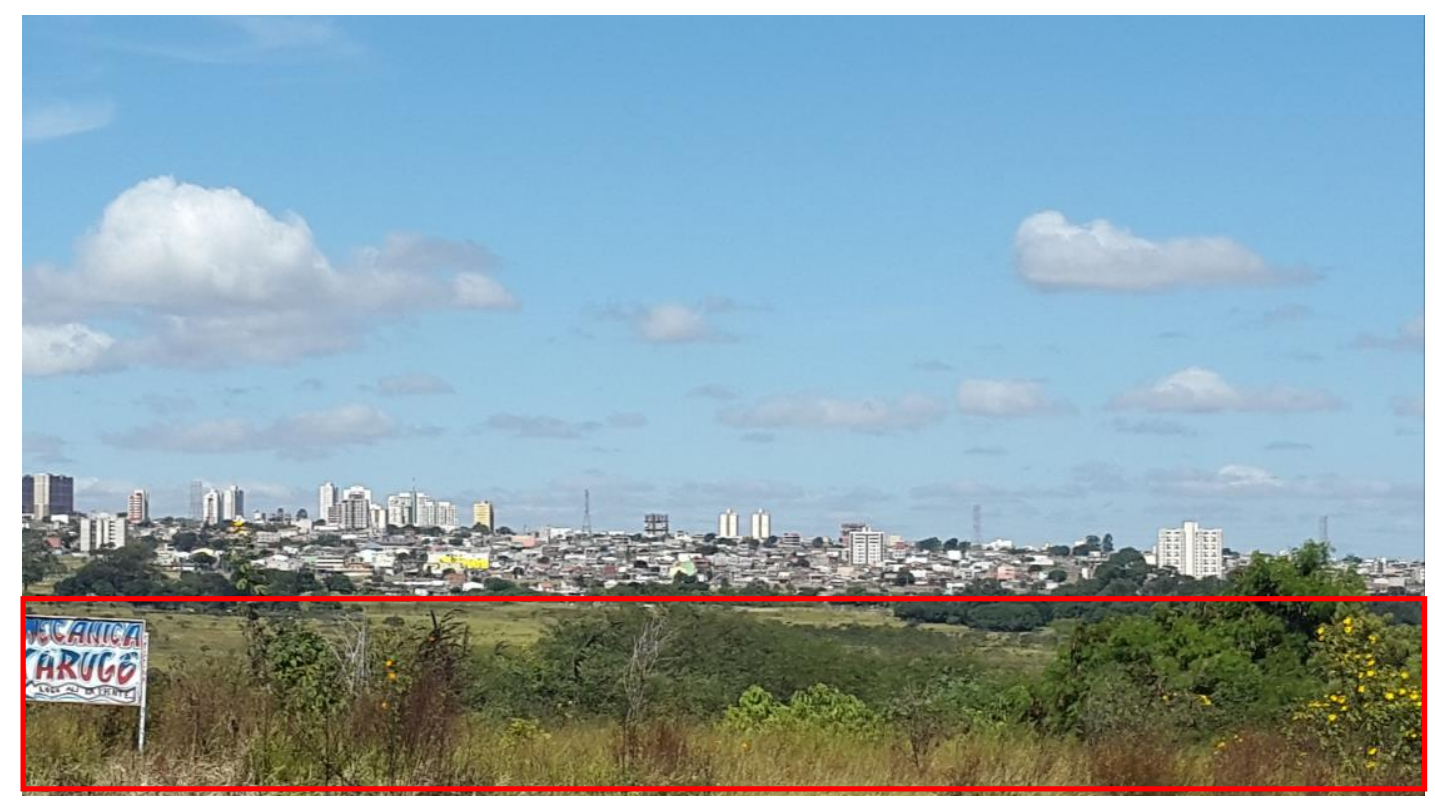

Figura 59: Áreas com nível de qualidade ambiental alto 


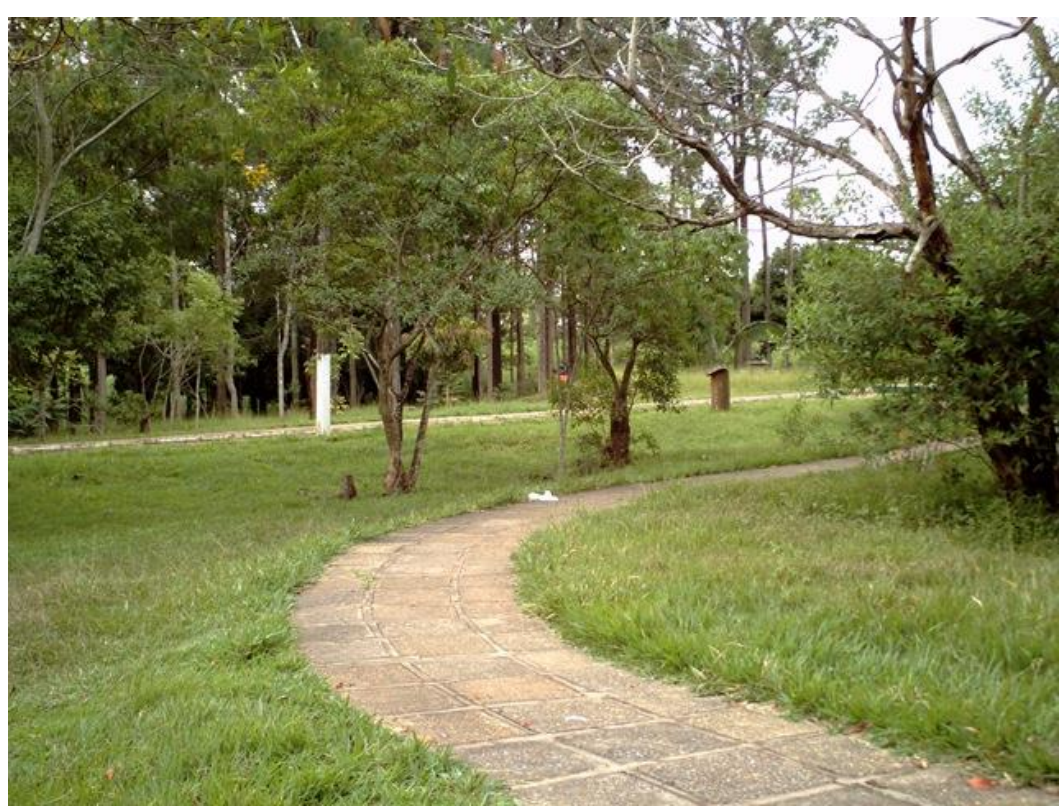

Figura 60: Parques

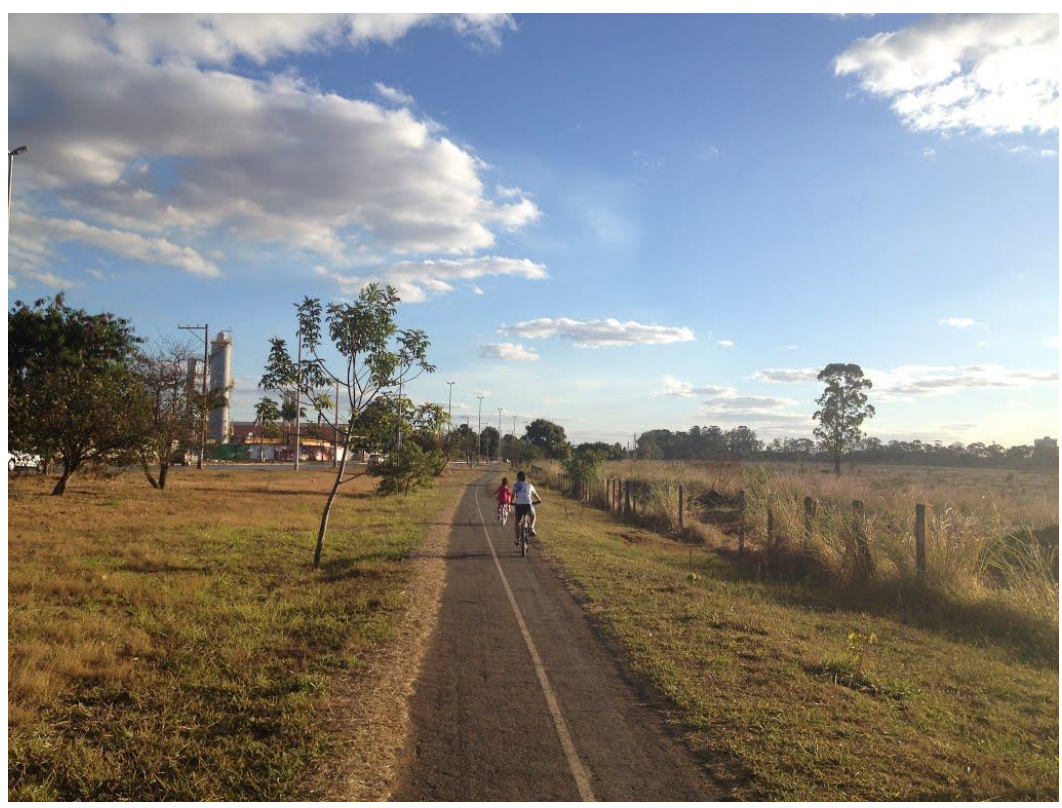

Figura 61: Prática de esportes 


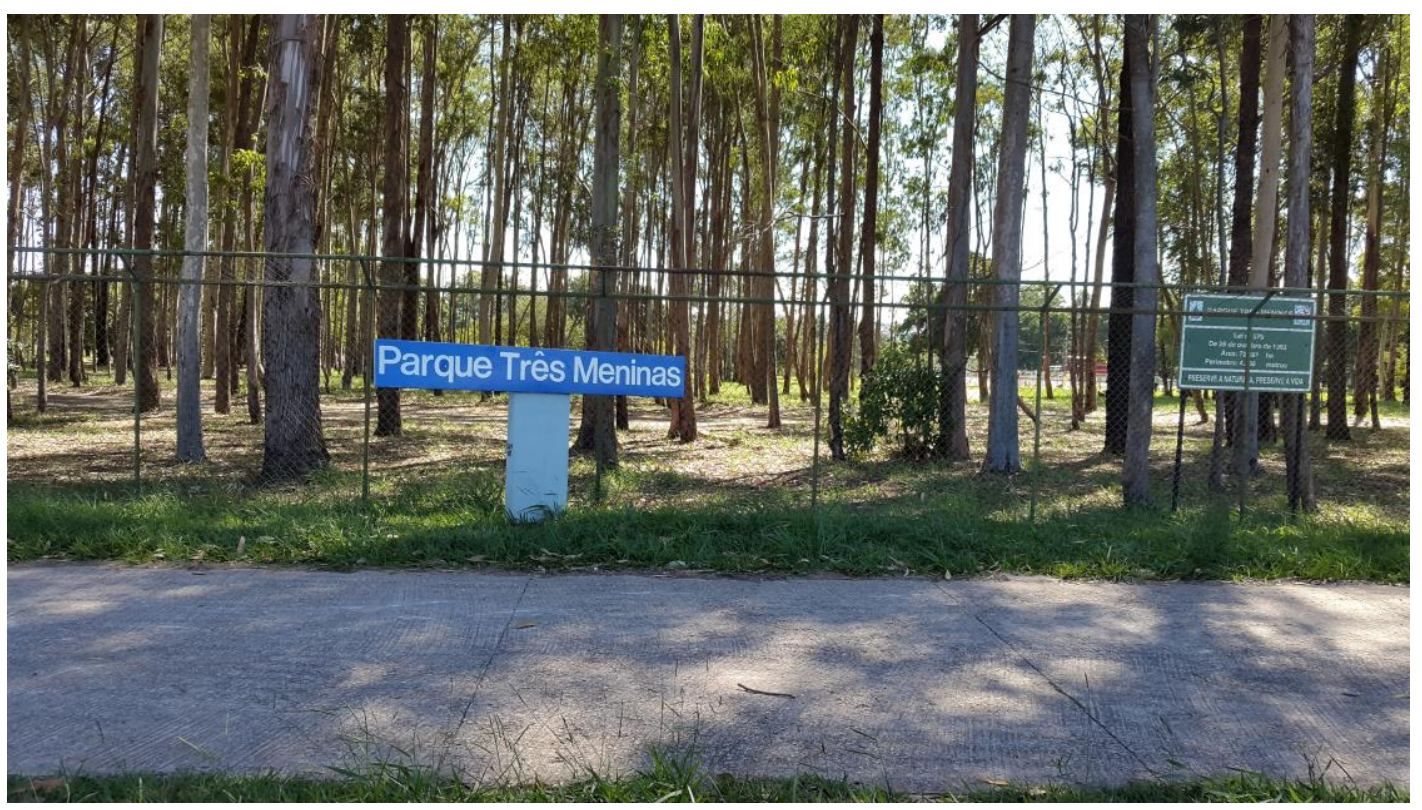

Figura 62: Áreas verdes

Observa-se que a área classificada com o nível muito alto de qualidade encontra-se margeando, ou próximo às redes de drenagem, portanto, pode-se deduzir que a mesma seja de mata de galeria que recebeu o maior peso no processo de julgamento do uso do solo, este o elemento com maior peso na segunda etapa de julgamento, integrando o meio físico que na terceira etapa de julgamento teve o maior peso em comparação com o saneamento, sendo, portanto a mata de galeria um dos elementos que maior influencia na qualidade ambiental da bacia. Este fato pode ser comprovado na Figura 63.

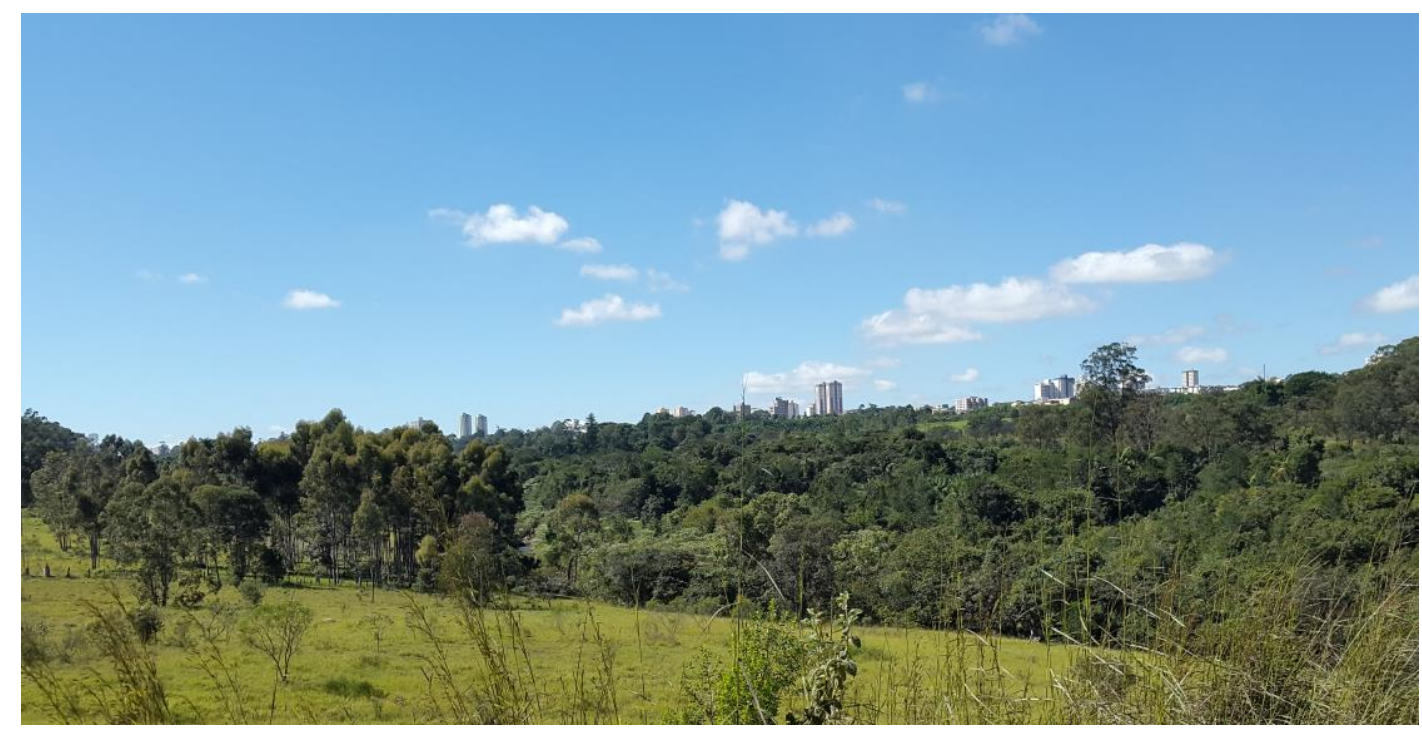

Figura 63: Áreas com nível de qualidade ambiental alto

A região sudoeste da bacia é onde se concentram os níveis de qualidade ambiental alto é médio, são áreas menos urbanizadas com maior cobertura vegetal, onde predomina as 
atividades rurais, com uma menor impermeabilização do solo, geração de resíduos sólidos e esgoto (Figura 64).

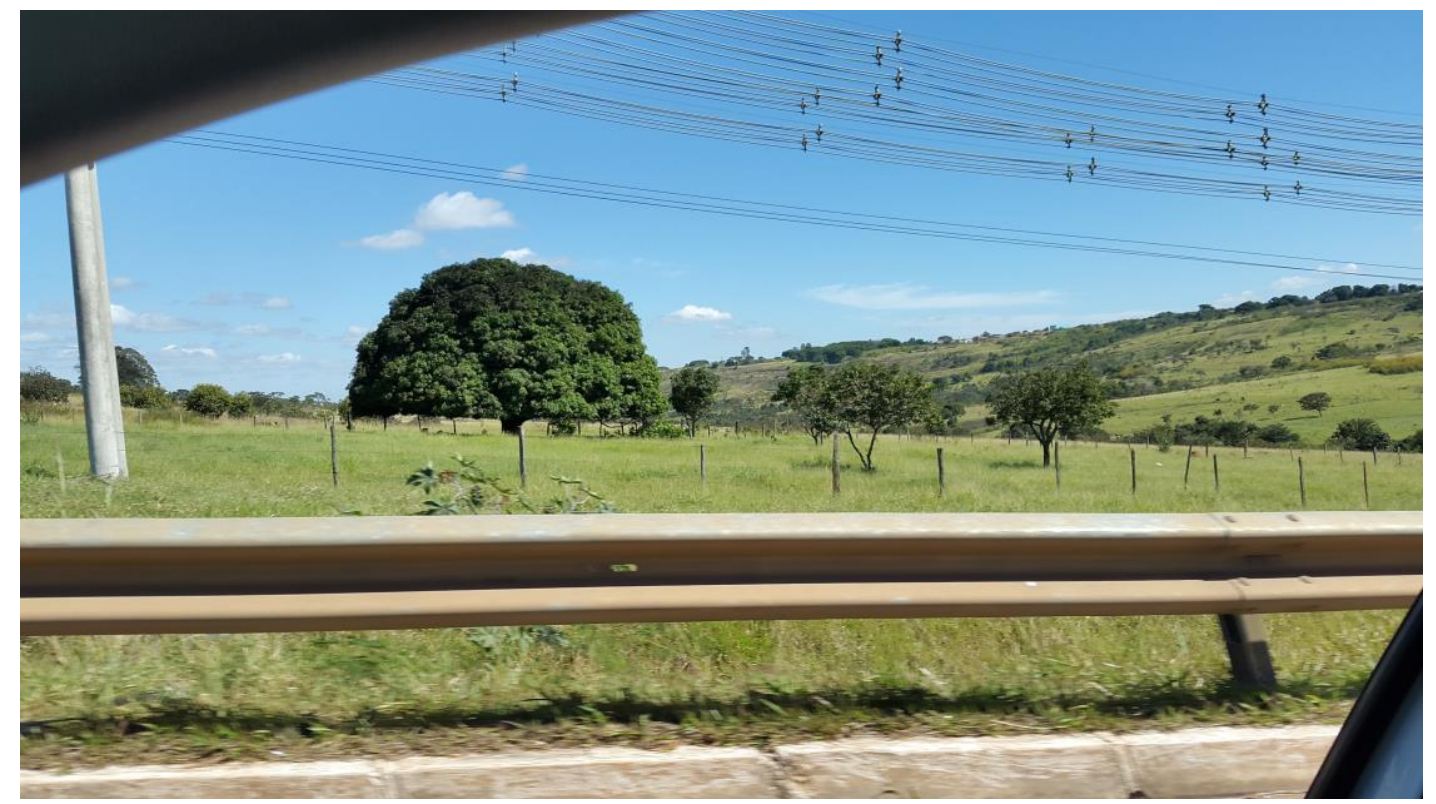

Figura 64: Áreas classificadas com o nível de qualidade médio

Vale ressaltar, que na área sudoeste da bacia encontra-se pequenas áreas com o nível de qualidade ambiental baixo e nulo, essas áreas são reflexos de pequenas ocupações, condomínios ou vilarejos (figura 65) instalados nesses locais, que devido a sua geração de resíduos sólidos, esgoto, impermeabilização do solo, falta de direcionamento de água, entre outros, contribuem para a área ter um menor nível de qualidade ambiental.

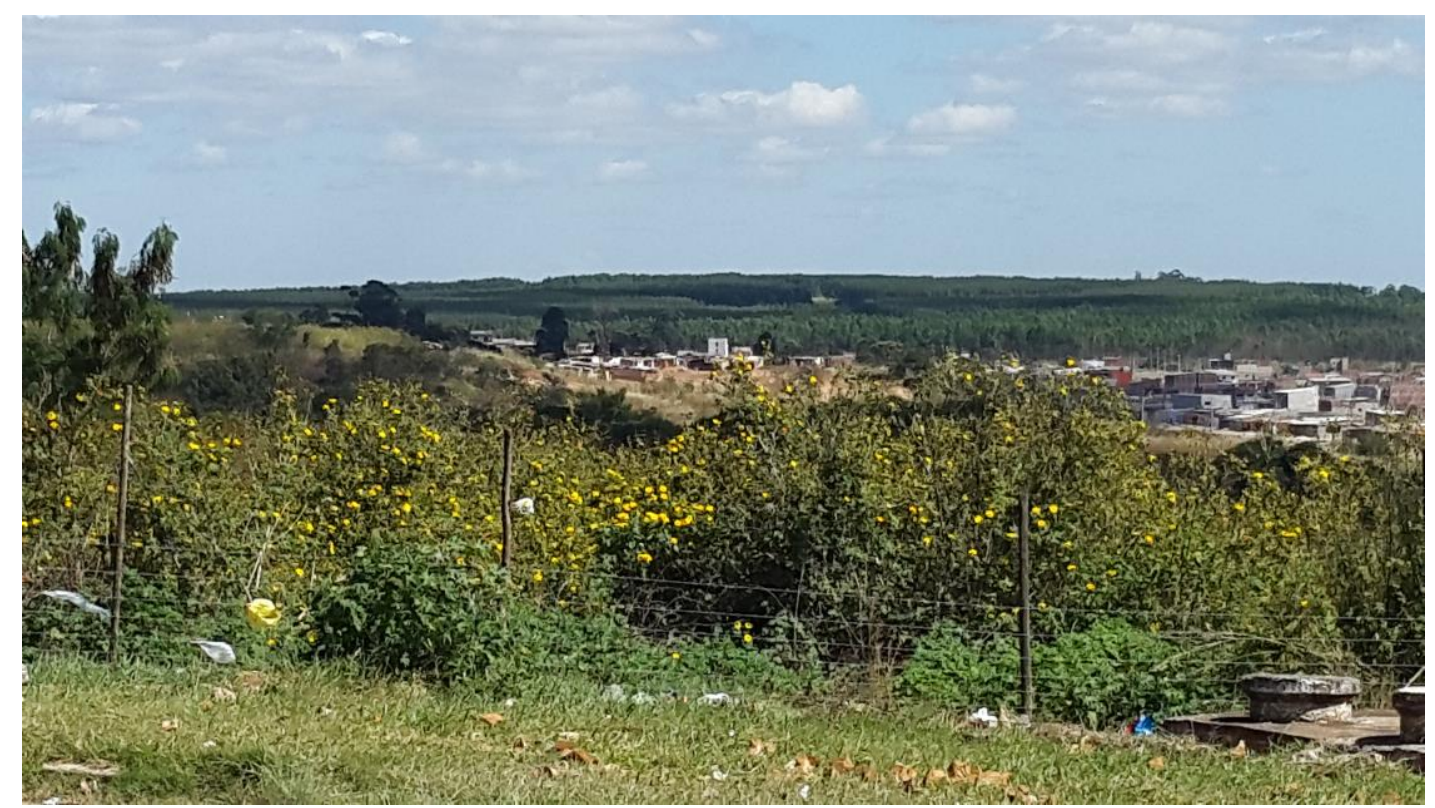

Figura 65: Pequenas ocupações localizadas na bacia 


\section{Capítulo 4 - Conclusões e Recomendações}

O resultado da presente pesquisa demonstrou a viabilidade da integração de ferramentas de geotecnologias e de aplicativos de análise hierárquica para modelagem de integração, visando analisar a qualidade ambiental de bacias hidrográficas, otimizando o tempo e garantindo a qualidade das informações e, consequentemente, otimizando mecanismos de tomada de decisões para os gestores ambientais.

Constatou-se que as áreas urbanas sem infrasestrutura são as que apresentaram maiores fragilidades ambientais e as áreas urbanas com instraestrutura com as maiores áreas impermeabilizadas, a maior geração de esgoto, de lixo e de consumo de água e as menores áreas verdes que propiciaram para sua qualidade ambiental serem classificadas como baixa. Faz-se necessário um olhar mais detalhado para esta parcela da bacia, com o intuito que os legisladores e gestores promovam um melhor planejamento ambiental, podendo assim melhorar o nível de qualidade ambiental da bacia em estudo.

O método mostrou-se útil para aplicações de análise de qualidade ambiental. No entanto, a integração dos métodos e modelos sinalizaram indicativos que devem ser observados em campo para uma melhor aplicação de medidas corretivas e ajuste a um planejamento ambiental de longo prazo.

O modelo AHP mostrou-se bastante versátil, permitindo a aplicação de critérios e alternativas na modelagem de processos de análise de qualidade ambiental da bacia, podendo ser utilizado por usuários de todas às áreas da ciência. No entanto, nos pesos definidos pelos especialistas na estruturação do modelo AHP, observou-se uma limitação na caracterização da qualidade ambiental da área urbana, o modelo não conseguiu demonstrar da mesma forma a qualidade ambiental da área urbana com infraestrutura, pois nela existe todo um sistema de fornecimento de água potável, coleta de lixo e sistema de coleta de esgoto. Com base nessa limitação recomenda-se uma maior extratificação da área urbana em função dos padrões existentes. 
Para a montagem da estrutura do modelo e necessario um número maior de profissionais para obtenção de um julgamento de pesos mais refinado, dando maior confiabilidade aos resultados.

Os dados obtidos do IBGE mostraram-se úteis e de grande importância para a realização da pesquisa, mas vale ressaltar que alguns não expressam bem a verdadeira realidadade da bacia, tais como os de esgotamento sanitário via rio, lago ou mar. Regiões como Taguatinga, Ceilândia e Samambaia são áreas urbanizadas com infraestrutura consolidada, que possuem orientação das águas pluviais, asfalto, rede de água, de luz e de esgotamento sanitário conforme apresentado nas figuras 26, 27 e 28, e que não possuem esgotamento sanitário via rio, lago ou mar. É importante que sejam analisados os dados do IBGE de forma detalhada retirando ou agrupando-os antes de usá-los para evitar a inserção de dados incorretos.

O Mapa de Qualidade Ambiental da Bacia do Rio Melchior - DF obteve dados satisfatórios, sendo assim as classes como, uso do solo, pluviosidade, pedologia, declividade, água, esgoto e lixo e os dados do julgamento de pesos demostraram eficiência na aferição do nível de qualidade ambiental da bacia do Melchior-DF.

Recomenda-se que para trabalhos futuros a atualização do modelo proposto na presente pesquisa seja realizada de forma a conseguir uma avaliação mais detalhada da bacia, aumentando os critérios e alternativas do modelo, com análises laboratoriais e in loco de água, solo e ar, que colaborarão com uma maior precisão nos resultados finais.

\section{Referências Bibliográficas}

ABRELPE. Panorama dos resíduos sólidos no Brasil 2013. Associação Brasileira de empresas de Limpeza, p. 114, 2013. São Paulo.

ALENCAR, A.; NEPSTAD, D.; MCGRATH, D.; et al. Desmatamento na Amazônia: Indo Além Da “ Emergência Crônica .” 1st ed. Belém, 2004.

ARAÚJO, L. E. DE; SOUSA, F. DE A. S. DE; NETO, J. M. DE M.; SOUTO, J. S.; REINALDO, L. R. L. R. Bacias Hidrográficas e impactos ambientais. Revista UEPB, v. 8, p. $1-18,2004$. 
BERNARDI, EWRTHON CEZAR SCHIAVO; PANZIERA, ANDRÉ GONÇALVES; BURIOL, GALILEO ADELI; SWAROWSKY, A. Bacia Hidrográfica como Unidade de Gestão Ambiental. Ciência Naturais e Tecnológicas, v. 13, p. 159-168, 2013.

BNDES. Bacias Hidrográficas Nova Gestão de Recursos Hídricos. Encontro Brasileiro de Economia e Ecológia, p. 1-12, 1998. Disponível em: <http://www.ecoeco.org.br/conteudo/publicacoes/encontros/i_en/mesa3/3.pdf >. .

BRASIL. Subsídios para a definição da Política Nacional de Ordenação do Território PNOT. .

BRASIL. Lei $\mathrm{n}^{\circ}$ 12.305, de agosto de 2013. Disponível em: <http://www.planalto.gov.br/ccivil_03/_ato2007-2010/2010/lei/112305.htm>. Acesso em: $4 / 4 / 2015$.

BRIDGE, B. Black Bridge Delivering the World. Disponível em: <http://www.blackbridge.com/rapideye/>. Acesso em: 14/1/2015.

CAllisto, M.; FERREIRA, W. R.; MORENO, P.; GOULART, M.; PETRUCIO, M. Aplicação de um protocolo de avaliação rápida da diversidade de habitats em atividades de ensino e pesquisa (MG-RJ). Acta Limnologica Bras, v. 14, p. 91-98, 2002. Disponível em: $<$ http://www.ablimno.org.br/acta/pdf/acta_limnologica_contents1401E_files/Artigo 10_14(1).pdf $>$. .

CARVALHO, A. P. V.; BRUMATTI, D. V.; DIAS, H. C. T. Importância do manejo da bacia hidrográfica e da determinação de processos hidrológicos. Revista Brasileira de Agropecuária Sustentável, v. 2, p. 148-156, 2012.

CODEPLAN. Mapas Topográficos Planialtimétricos Digitais do Distrito Federal na escala de 1:10.000. GDF, 1992. Brasília.

CONAMA. Resolução CONAMA N ${ }^{0}$ 001, de 23 de janeiro de 1986. Disponível em: <http://www.mma.gov.br/port/conama/res/res86/res0186.html>. Acesso em: 5/5/2014.

COSTA, H. G. Introdução ao Método de Análise Hierárquica. XXXVI - SBPO, v. 1, 2004. Disponível em: <http://www.din.uem.br/sbpo/sbpo2004/pdf/arq0279.pdf>. .

COSTA, T. PIRES; PERIN, A. CAROLINA DA MOTTA. A Gestão dos recursos hídricos no Brasil. Revista da Faculdade de Direito, 2000.

COUTINHO, M. P.; MEDEIROS, J. DE D.; SORIANO, É.; et al. O Código Florestal Atual ( Lei Federal $\mathrm{n}^{\circ}$ 12.651/2012) e suas implicações na prevenção de desastres naturais. Sustentabilidade em Debate, v. v.4, p. 237-256, 2013. Disponível em: <http://periodicos.unb.br/index.php/sust/article/viewFile/9439/7370>. .

EMBRAPA. Mapa Pedológico Digital - SIG Atualizado do Distrito Federal Escala 1:100.000 e uma Síntese do Texto Explicativo. Planaltina, DF, 2004. 
EXPERT CHOICE. Expert Choice Decision Making Methodology. Disponível em: <http://expertchoice.com/about-us/our-decision-making-methodology/>. Acesso em: 20/8/2015.

EXPERT CHOICE RESOURCE ALIGNER. Programa de computador. Expert Choice (versão 3.01), 2004. Estados Unidos.

FARIA, A. L. L. DE; SILVA, J. X. DA; GOES, M. H. DE B. ÁREAS COM SUSCEPTIBILIDADE À EROSÃO DO SOLO NA BACIA HIDROGRÁFICA DO RIBEIRÃO DO ESPÍRITO SANTO, JUIZ DE FORA ( MG ). CAMINHOS DE GEOGRAFIA, v. 4, n. 9, p. 50-65, 2003.

FARIA, R.; PEDROSA, A. Aplicação dos SIG na Elaboração de Cartografia Temática de Base na Bacia hidrográfica do Rio Uima, Santa Maria da Feira. Anais do XI Simpósio Brasileiro de Geografia Física Aplicada, v. 9, p. 13, 2005. Disponível em: $<$ http://www17.brinkster.com/minuss/XI-sbgfa.htm>. .

FELIX, I. M.; KAZMIERCZAK, M. L.; ESPINDOLA, G. M. DE. RapidEye: a nova geração de satélites de Observação da Terra. XIV Simpósio Brasileiro de Sensoriamento Remoto, p. 7619-7622, 2009.

FLORESTA, S. Cartilha Código Florestal. Disponível em: <www.agricultura.gov.br/arq_editor/file/camaras_setoriais/.../cartilhaCF.pdf>. Acesso em: $27 / 1 / 2015$.

FRANCO, J. L. D. A. O que podemos fazer para evitar a destruição de nosso mundo? Sociedade e Estado, v. 24, n. 1, p. 293-299, 2009.

FREITAS, C. G. L. DE. Planos Diretores Municipais: Integração Regional Estratégica. Porto Alegre, 2007.

FREITAS, M. DE; RANGEL, D.; DUTRA, L. Gestão de recursos hídricos no Brasil : a experiência da Agência Nacional de Águas. Agência Nacional de Águas, 2000.

GARCIA, Y. M. O código florestal brasileiro e suas alterações no congresso nacional. Revista Geografia em Atos, v. 1, p. 54-74, 2012. Disponível em: <http://revista.fct.unesp.br/index.php/geografiaematos/article/viewFile/1754/iarama>. .

GDF. Zoneamento Ecológico Econômico do Distrito Federal / ZEE-DF. Disponível em: <http://www.zee-df.com.br/>. Acesso em: 24/1/2015.

GONÇALVES, T. D. Geoprocessamento como ferramenta de apoio à gestão dos recursos hídricos subterrâneos do Distrito Federal, 2007. Brasília: Universidade de Brasília.

HEIN, M. Espacialização de duas microbacias hidrográficas do Rio Piracicaba para modelagem hidrológica, 2000. Campinas: Universidade Estadual de Campinas. Disponível em: <http://www.bibliotecadigital.unicamp.br/document/?code=vtls000219695\&fd=y>. . 
IBAMA. Incêndios Florestais. Disponível em: <http://www.ibama.gov.br/prevfogo >. Acesso em: 14/1/2015.

IBRAM. Bacias do DF. Disponível em: <http://www.ibram.df.gov.br/informacoes/recursoshidricos.html>. Acesso em: 4/9/2015.

INPE. Monitoramento de Queimadas e Incêndios. Disponível em: <http://www.inpe.br/queimadas/estatisticas.php>. Acesso em: 25/1/2015.

LOPES, L. F. A Bacia Hidrográfica Como Unidade de Planejamento. Portal do Professor, $2010 . \quad$ Disponível em: <http://portaldoprofessor.mec.gov.br/fichaTecnicaAula.html?aula=27049>. .

LOPES, P. M. .; PEJON, O. . Obtenção Da Carta De Susceptibilidade À Erosão Com Auxílio Do Sig-Idrisi: Subsídio Para O Zoneamento Geoambiental Da Bacia Do Rio Passa Cinco E Rio Da Cabeça - Sp. VII Simpósio Nacional de Controle de Erosão, p. 1-10, 2001. Disponível em: <http://www.labogef.iesa.ufg.br/links/simposio_erosao/articles/T020.pdf>. .

MACEDO, M. JUNIOR BRITO. A influência do uso, da ocupação e da conservação do solo na qualidade da água de abastecimento: o caso da bacia hidrográfica do lago descoberto, 2004.

MARINHO, C. A. B. Proposta de ferramenta computacional para discriminação de feições espectrais de óxidos de ferro em solos da região agrícola do df, por meio do sensor aerotransportado ads-80., 2014. Universidade de Brasília.

MARINS, C. S.; SOUZA, D. DE O.; BARROS, M. DA S. O uso do método de análise hierárquica (AHP) na tomada de decisões gerenciais - um estudo de caso. XLI SBPO 2009 Pesquisa Operacional da Gestão do Conhecimento, p. 1778-1788, 2009.

MARTINS, F. B.; SALES, J.; ROBAINA, A. D.; et al. Zoneamento Ambiental da Sub-Bacia hidrográfica do arroio cadena, Santa Maria (RS) - (estudo de Caso). Cerne, Lavras, v. 11, p. 315-322, 2005.

MENDOZA, M. E.; LÓPEZ, E.; GENELETTI, D.; PÉREZ-SALICRUP, D. R. Analysing land cover and land use change processes at watershed level: A multitemporal study in the Lake Cuitzeo Watershed, Mexico ( 1975 e 2003 ). Applied Geography, v. 31, n. 1, p. 237250, 2011. Elsevier Ltd. Disponível em: <http://dx.doi.org/10.1016/j.apgeog.2010.05.010> . .

MENESES, P. R.; ALMEIDA, T. DE. Introdução ao processamento de imagem de sensoriamento remoto. 1st ed. Brasilia, 2012.

MINISTÉRIO DA INTEGRAÇÃO NACIONAL. Para pensar uma política nacional de ordenamneto territorial. 32nd ed. 2005.

MORAES, S. R. R. DE; TUROLLA, F. A. Visão geral dos problemas e da política ambiental no brasil. Informações Econômicas, v. 34, 2004. 
NOVAES, W.; RIBAS, O.; NOVAES, P. DA C. Agenda 21 Brasileira - Bases para discussão. Disponível em: <http://www.pucsp.br/ecopolitica/projetos...principais.../Agenda21 Brasil.pdf>. Acesso em: 15/1/2015.

NOVAIS, V. M. DA S. Desafios para uma efetiva gestão ambiental no Brasil. , p. 1-14, 2011.

NUNES, J. F. O Modelo LUCIS e o Planejamento Territorial da Bacia do Alto Rio Descoberto O Modelo LUCIS e o Planejamento Territorial da Bacia do Alto Rio Descoberto, 2014. Universidade de Brasília. Disponível em: <http://www.repositorio.unb.br/handle/104882/16811>. .

OLIVEIRA, R. C. S.; MEDEIROS, R. M. DE; NETO, F. DE A. DA C.; MENEZES, H. E. A. Impactos ambientais da urbanização na bacia hidrográfica do rio uruçuí preto (piaui). Agricultura familiar, natureza e segurança alimentar, 2014.

ORGANIZATION, W. M. The Dublin Statement $\mathrm{n}$ water and sustainable development. Disponível em: <http://www.wmo.int/pages/prog/hwrp/documents/english/icwedece.html>. Acesso em: 9/2/2015.

PEIXOTO, M. C. D. Expansão urbana e proteção ambiental: um estudo a partir do caso de Nova Lima /MG. XI Encontro Nacional de Pós-Graduação e pesquisa em Planejamento Ambiental Urbano e Regional - ANPUR, 2005. Disponível em: <http://www.anpur.org.br/revista/rbeur/index.php/anais/article/viewFile/2733/2673>. .

PERES, R. B.; CHIQUITO, E. DE A. Ordenamento Territorial, Meio Ambiente e Desenvolvimento Regional. Revista Brasileira de Estudos Urbanos e Regionais, v. 14, n. 2, 2012.

PINTO, S. DOS A. F.; GARCIA, G. J. Experiências de aplicação de geotecnologias e modelos na análise de bacia hidrográficas. Revista do Departamento de Geografia, v. 17, p. 30-37, 2005. Disponível em: $<$ http://www.geografia.fflch.usp.br/publicacoes/RDG/RDG_17/Sergio_dos_Anjos_Ferreira_P into.pdf $>$. .

PIROLI, E. L.; CAMPOS, S. Análise do uso da terra por classes de declividade em microbacia hidrográfica usando geoprocessamento. Pesquisa Aplicada \& Agrotecnologia, v. 2, p. 7-20, 2009.

PORTO, R. L. LAINA; PORTO, M. F. A. Gestão de bacias hidrográficas. , v. 22, n. 63, p. 43-60, 2008.

PUSSININI, N. A gestão urbana e ocupação em áreas de preservação permanente na cidade de Guarapuava ( PR ): o caso do arroio do Carro Quebrado. Ambiência - Revista do Setor de Ciências Agrárias e Ambientais, v. 7, p. 133-153, 2011.

REIS, HARIANI LUIZI ALMEIDA DOS; NOGUEIRA, LUCAS NEVES BRITO; FRANCO, MARCELO NASCIMENTO SILVA; et al. Índice de Qualidade da Água do 
córrego Vicente Pires-DF, sua relação com o uso e ocupação do solo e influência sobre o córrego Riacho Fundo-DF. , p. 928-935, 2013.

RIBEIRO, J. C.; SALOMÃO, F. X. T. a Morfopedologia Aplicada Ao Diagnóstico E Prevenção Dos Processos Erosivos Lineares Da Bacia Hidrográfica Do Alto Rio Da Casca. VII Simpósio Nacional de Controle de Erosão, p. 1-9, 2001.

RIBEIRO, M. O. Estudo da poluição e autodepuração nos rios Melchior e Descoberto, na bacia do Descoberto - DF / GO, com auxílio de modelos matemáticos de simulação de qualidade de água, para estudos de seu comportamento atual e futuro, 2001. Universidade de Brasília - UnB.

RÜCKERT, A. A. A política nacional de ordenamento territorial, Brasil. Uma política territorial contemporânea em construção. REVISTA ELECTRÓNICA DE GEOGRAFÍA Y CIENCIAS SOCIALES, v. XI, 2007. Disponível em: <http://www.ub.edu/geocrit/sn/sn24566.htm>. .

SÁ, T. F. F. DE; FILHO, J. F. DA C.; FRANCISCO, P. R. M.; JÚNIOR, J. M. B. Sistema de informações geográficas (SIG) para a gestão ambiental de bacias hidrográficas. III Simpósio Brasileiro de Ciências Geodésicas e Tecnologias da Geoinformação, p. 27-30, 2010.

SÁNCHEZ, L. E. Avaliação de impacto ambiental. $1^{0}$ ed. São Paulo: Oficina de textos, 2008.

SANTOS, É. P. DOS; LEAL, A. C. Contribuição para o planejamento ambiental da bacia hidrográfica do ribeirão do rebojo - ugrhi pontal do paranapanema - são paulo. Revista Geonorte, v. 3, n. 4, p. 791-802, 2012.

SCHIAVETTI, A.; CAMARGO, A. F. M. Conceitos de bacias hidrográficas: teorias e aplicações. 2002.

SEDHAB. PDOT - Processo de Atualização. Disponível em: $<$ http://www.sedhab.df.gov.br/desenvolvimento-urbano/planejamento-urbano/pdot/processode-atualizacao-pdot.html>. Acesso em: 5/5/2014.

SEDHAB. Plano Diretor de Ordenamento Territorial do Distrito Federal (2015). Disponível em: <http://www.sedhab.df.gov.br/...urbano/...pdot/processo-de-atualização-pdot.html>. Acesso em: 15/1/2015.

SENADO FEDERAL. Agenda 21 - Conferencia das Nações Unidas sobre meio ambiente e desenvolvimento. Disponível

em: $<$ http://www.meioambiente.pr.gov.br/arquivos/.../Agenda_21_Global_Sistese.pdf >. Acesso em: $20 / 1 / 2015$.

SHARAFI, S. M.; MOILANEN, A.; WHITE, M.; BURGMAN, M. Integrating environmental gap analysis with spatial conservation prioritization: a case study from Victoria, Australia. Journal of environmental management, v. 112, p. 240-51, 2012. Disponível em: <http://www.ncbi.nlm.nih.gov/pubmed/22935646>. Acesso em: 5/2/2014. 
SILVA, A. C.; TORRADO, P. V.; PÉREZ, M. G.; NETO, L. M.; VASQUEZ, F. M. Relações entre matéria orgânica do solo e declividade de vertentes em toposseqüência de latossolos do sul de Minas Gerais. Revista Brasileira de Ciencia do Solo, v. 31, n. 5, p. 1059-1068, 2007.

SILVA, G. J. A. DA; WERLE, H. J. S. Planejamento urbano e ambiental nas municipalidades da cidade à sustentabilidade, da lei à realidade. Revista eletrônica da área Paisagem e Ambiente FAU.USP, , n. 1, p. 1-24, 2007.

SILVA, J. A. A. DA; NOBRE, A. D.; JOLY, C. A.; et al. O código florestal e a ciência: Contribuições para o diálogo. 2nd ed. São Paulo: Sociedade Brasileira para o Progresso da Ciência - SBPC, 2012.

SILVA, J. D. S. V. DA. Análise multivariada em zoneamento para planejamento ambiental Estudo de caso: bacia hidrográfica do alto rio Taquari MS/MT, 2003. Universidade Estadual de Campinas.

SILVA, J. X.; ZAIDAN, R. T. Geoprocessamento \& Meio Ambiente. Rio de Janeiro: Bertrand Brasil, 2011.

TEODORO, V. L. LOST; TEIXEIRA, D.; COSTA, D. J. L.; FULLER, B. B. O conceito de bacia hidrográfica e a importância da caracterização morfométrica para o entendimento da dinâmica ambiental local. REVISTA UNIARA, , n. 20, p. 136-157, 2007.

TUCCI, C. E. M. Plano diretor de drenagem urbana: princípios e concepção. RBRH Revista Brasileira de Recursos Hídricos, v. 2, n. i, p. 5-12, 1997. Disponível em: <http://www.rhama.net/download/artigos/artigo2.pdf>. .

TUCCI, C. E. M.; MENDES, C. A. Avaliação Ambiental Integrada de Bacia Hidrográfica. 2nd ed. Brasília, 2006.

VERONEZZI, F. Novo Código Florestal: Bom ou Ruim? Disponível em: $<$ http://www.guiadacarreira.com.br/atualidades/codigo-florestal-brasileiro/>. Acesso em: $4 / 9 / 2015$.

XAVIER, LUCY DA S. S. Implicações socioambientais do turismo e o licenciamento na Bacia do Rio Formoso, Bonito, MS, 2011.

ZAMARIOLA, N.; LEITE, M. A.; CANDELÁRIA, M. C. Análise preliminar da disposição dos resíduos no Cinturão Verde - Ilha Solteira ( SP ). , , n. 2002, 2010.

ZANATA, J. M.; PIROLI, E. L.; DELATORRE, C. C. M.; GIMENES, G. R. Análise do uso e ocupação do solo nas áreas de preservação permanente da microbacia ribeirão bonito, apoiada em técnicas de geoprocessamento. Revista GEONORTE, v. 2, n. 4, p. 1262-1272, 2011. Disponível em: <http://www.rimaeditora.com.br/04_Anais.pdf>. .

ZHAO, M.; ZHANG, Y.; MA, W.; et al. Characteristics and ship traffic source identification of air pollutants in China's largest port. Atmospheric Environment, v. 64, p. 277-286, 2013. 
ZHOU, J.-L.; BAI, Z.-H.; SUN, Z.-Y. A hybrid approach for safety assessment in high-risk hydropower-construction-project work systems. Safety Science, v. 64, p. 163-172, 2014. Elsevier Ltd. Disponível em: <http://linkinghub.elsevier.com/retrieve/pii/S0925753513003147>. Acesso em: 3/4/2014. 